\title{
الحاضنات التكنولوجية \\ كمدخل لتطوير دور الجامعة في خدمة المجتمع
}

\author{
إعداد \\ الاكتور \\ مصطفى أحمد أمين \\ المدرس بقسم أصول التربية \\ كلية التربية - جامعة دمنهور
}

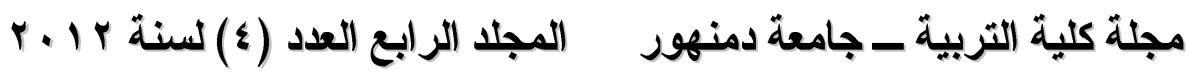


الحاضنات التكنولوجية كمدخل لتطوير دور الجامعة في خدمة المجتمع د/ مصطفى أحمد أمين

مقدمة

يعد التعليم الجامعي مفتاح تقدم الشعوب والأمم وأساس البناء و آلية

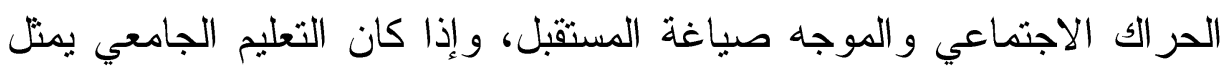

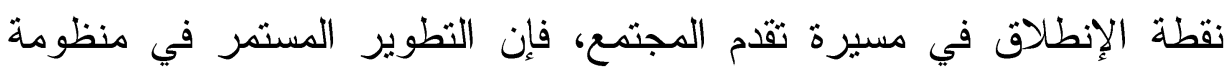

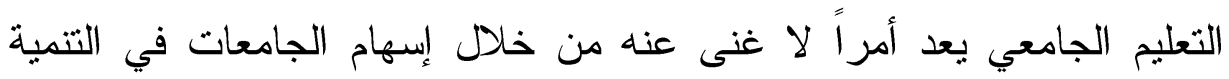
الاقتصادية و الاجتماعية في المجتمع.

ولما كانت الجامعات من أبرز المؤسسات الاجتماعية التي تثؤثر وتتأثر بالمحيط الاجتماعي و الاقتصادي و السياسي و التكنولوجي الموجود فيه، فالجامعة الهونة

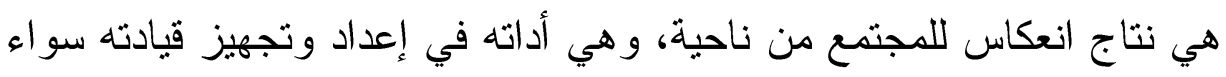

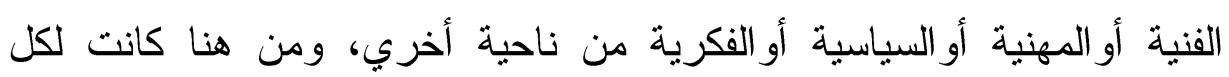
جامعة رؤيتها ورسالتها التي تقوم على تحقيقها. ومع ما تشهده الجامعات من تحديات وتغيرات، انعكست على ورئ وظائف

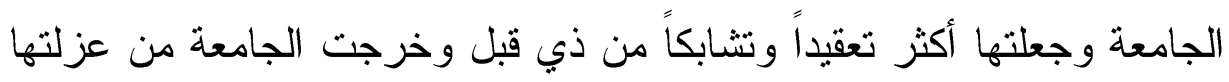

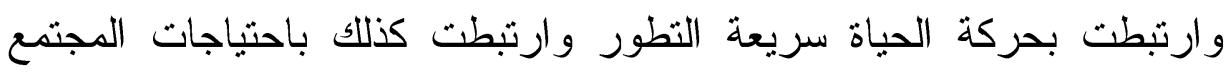

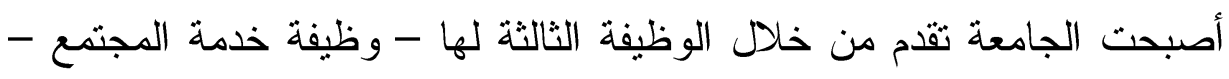

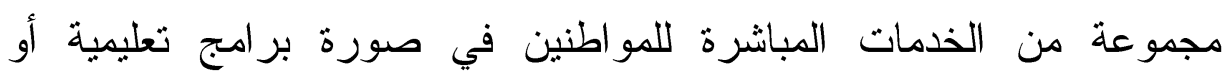
استشارية أو تدريبية أو بحثية لقطاعات الصناعة والإنتاج و الخدمات معاً بما يؤدي إلى تحسين نواتجهما وتطوير العلاقة بينهما.

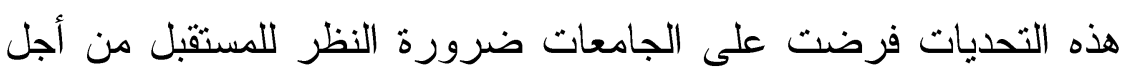
تطوير أدوارها، واعتمدت على بعض الاستر اتييات في التطوير منها

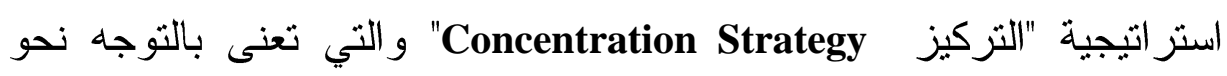
المزيد من التخصص في تقديم الخدمات أو المنتجات أو في خدمة الأسواق أو 
المناطق الجغر افية، أو لتعامل مع فئات محددة من المستقيدين من الخدمة

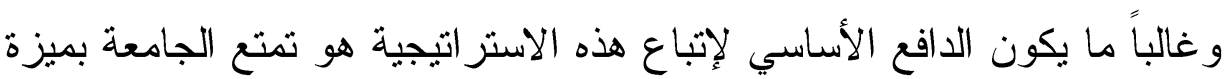

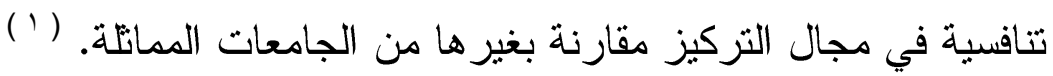

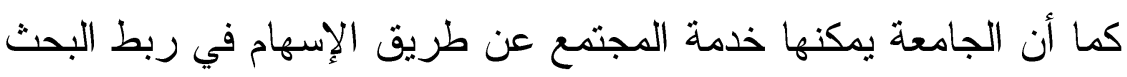

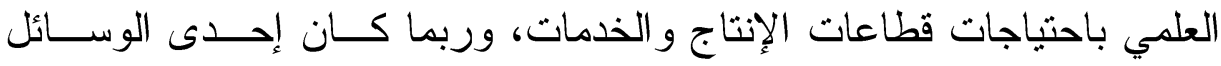
لتحقيق هذا الارتباط هو إقامة الحاضنات التكنولوجية التي وتعمل على توطيد العلاقة بين الجامعات وقطاعات الإنتاج و الخدمات، التي ترغب في الحصول

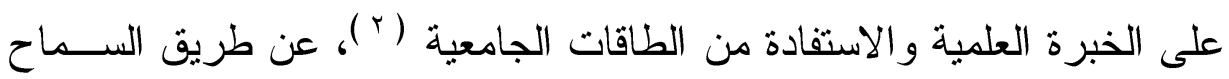

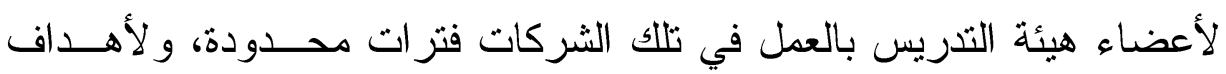

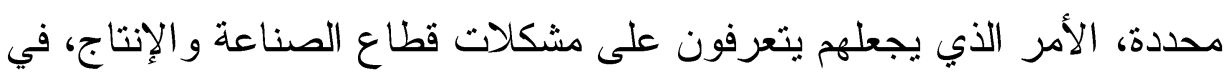

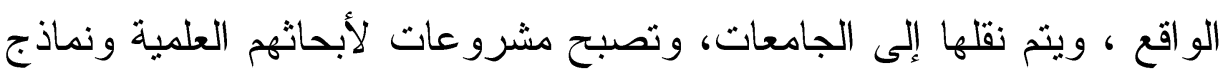

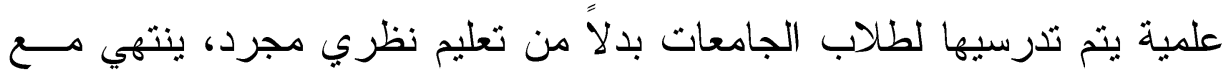
الزمن إلى عزلة الجامعات عن مجتمعاتها. لذللك تعد الحاضنات النكنولوجية أحد المداخل الحديثة في تطوير العلاقة بين الجامعة وقطاعات المجتمع في خدمة المجتمع وتقليل حجم الفجوة بينهما، وبالتالي يصبح دور تلاك الحاضنات التكنولوجية أعمق في تطوير دور الجامعة

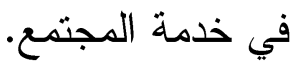
وتتميز الحاضنات التكنولوجية بوجود وحدات الاعم العلمي التكنولوجي، و التي تقام بالتعاون مع الجامعات ومر اكز الأبحاث، وتهدف إلى الاستفادة من

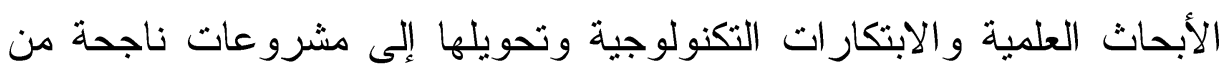
خلا الاعتماد على البينة الأساسية لهذه الجامعات من معامل وورش وأجهزة

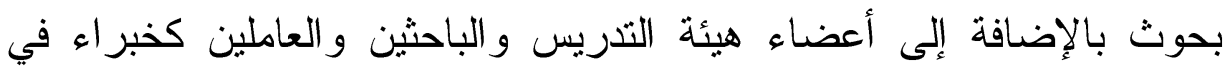
تخصصاتهم (r) بحالافن 
وتهدف الحاضنات التكنولوجية إلى تسويق العلم والتكنولوجيا من خلال

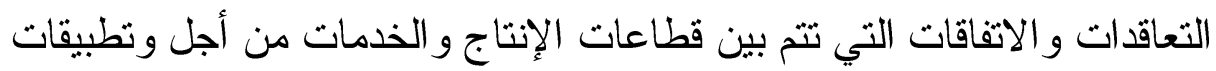
البحث العلمي، فهي الحاضنات التكنولوجية ترتكز على الشر اكة و التعاون

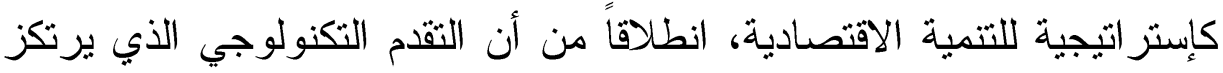

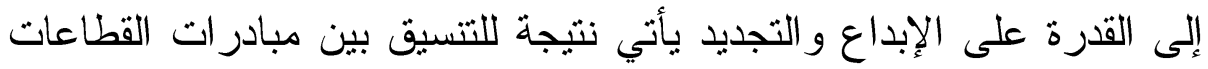

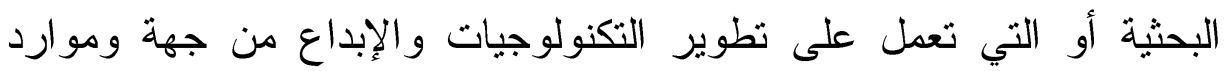
الدولة والقطاع الخاص من جهة أخرى. لذلك، فان الحاضنات التكنولوجية تستطيع دعم جهود المجتمع في إقامة تتمية تكنولوجية حقيقية، وتتشيط البحث العلمي من خلال رعاية التعاون بين أصحاب الأفكار الإبداعية و الباحثين

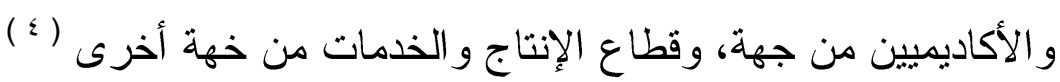

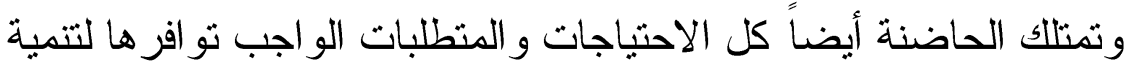
المشروعات الملتحقة بها من خلال إمداد تلك المشروعات بكل ما تحتاجها من عو امل النمو و التقوية لينهض ويستقر ويظهر للوجود، إذ تعتبر الحاضنة إطار يدعم ويمكن أصحاب المشاريع ورجال الأعمال من تبني الأفكار التكنولوجية المبتكرة من قبل الخبراء و المفكرين على حد سواء، حيث ثقوم بأخذ الأفكار

وتطوير ها

وتعمل الحاضنات على زيادة نسبة نجاح المشروعات الصغيرة البادئة و المتوسطة من .0\% - . ٪ \% ، وتعمل على توطيد العلاقة بين الجامعات و الشركات الصناعية التي ترغب في الحصول على الخبرة العلمية والاستفادة

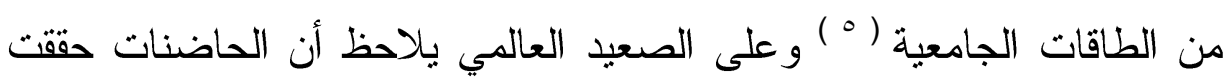

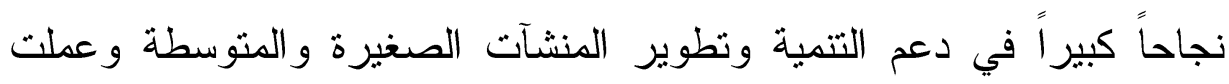

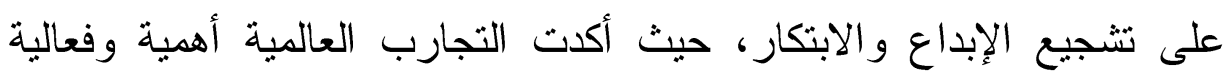
دورها في نجاح و استمر ار نسبة حوالي ه10\% - .9\% من المشروعات التي 
تخرجت من الحاضنات مقابل حو الي .0 \% من المشروعات التي تم إنشاؤها

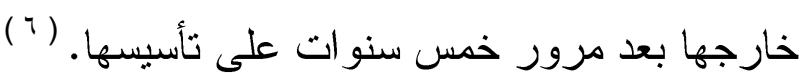
هذا بالإضافة إلى أن الدور الرئيس للحاضنات التكنولوجية يتركز حول بـات مشروعات الأعمال الصغيرة بوصفها أكثر قابلية للتغيير و التطوير و أكثر تقبلاً للأفكار المستحدثة، وبالتالي يمكن أن تتطور بصورة أسرع و أكفأ من المنشآت

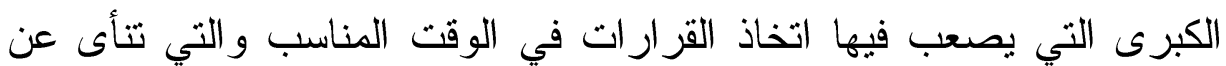
أي مجازفة بالدخول في مغامرات غير مضمونة العو اقب ( ₹ )، حيث أسفرت

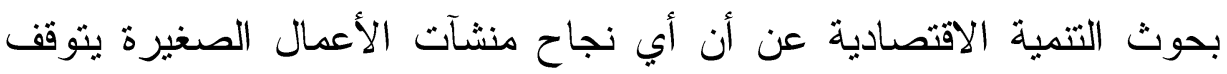
على مدى العون الجاد والدعم المكثف الذي تتلقاه تلك المنشآت في البداية حتى التى تجتاز مصاعب المراحل الأولى من إنشائها، كما كثفت تلأك البحوث أيضاً عن

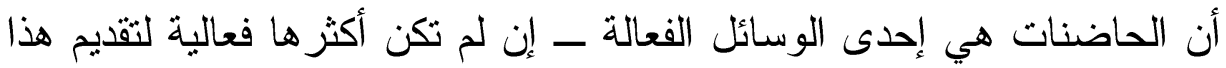

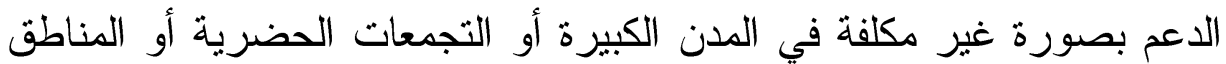
القروية (^)

بناءً على ما سبق يمكن القول بأن أبرز ما يميز أسلوب الحاضنات التكنولوجية هو تللك الخدمات التي تقدمها لقطاعات المجتمع المختلفة والتي لتي تتمتع في الغالب بإمكانات النمو المرتفعة، وتعمل على مساعدة هذه القطاعات في التغلب على المشكلات التي قد تتؤدي إلى فشلها أو عجزها هان عن تحقيق

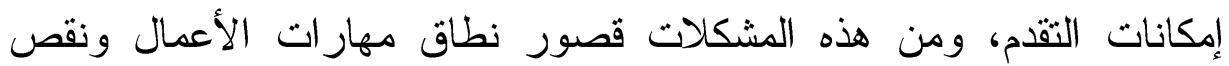
التمويل، وذلك عن طريق تطبيق الأبحاث والابتكارات العلمية المتطورة في مشروعات صناعية انتاجية لتصنيع منتجات ذات تثنية عالية ولها قدرات تنافسية في الاسواق العالمية. مشكلة الار اسة فئة

على الرغم من أن التعليم الجامعي يسعى إلى الحرص على البقاء و الاستمر ار والنمو و التوسع في ظل التحديات العالمية و إلى التوسع في تقديم 
المزيد من الخدمات للمجتمع لتقليل الفجوة بينهما، فإن هناك عديد من المؤشرات تشير إلى قصور في ربط مؤسسات التعليم الجامعي بمؤسسات

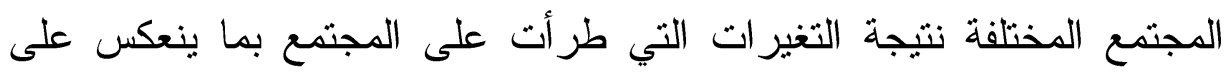

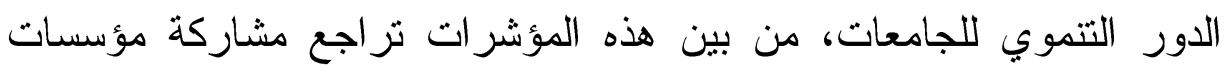

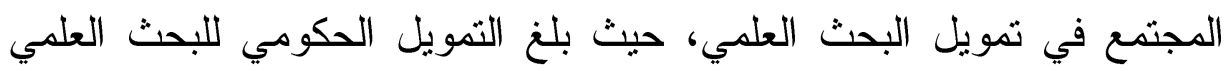

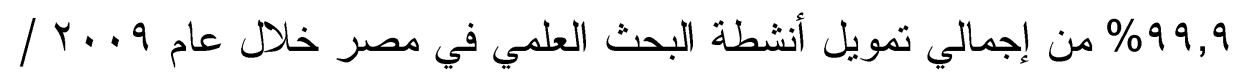

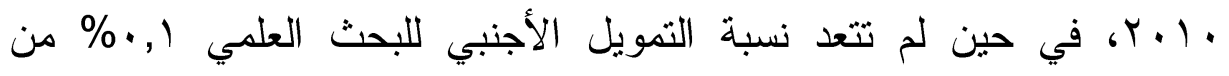

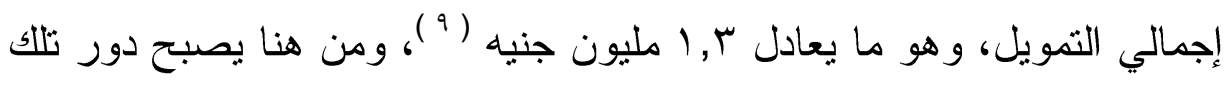

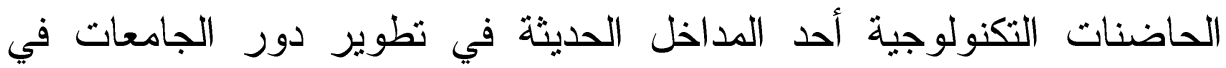
خدمة المجتمع عن طريق إجراء البحوقث العلمية وتقديم الخدمات للقطاعات المجتمعية المختلفة. تهدف الدر اسة إلى الإجابة عن التساؤلات الآتية:

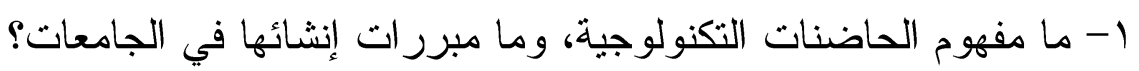

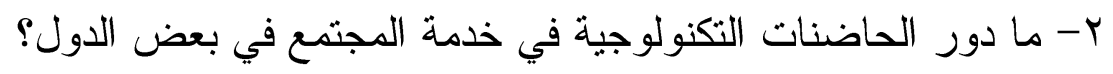

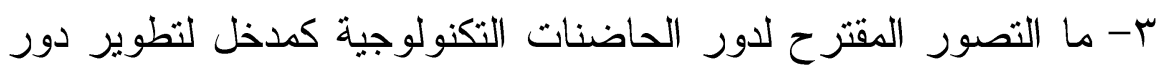
الجامعة في خدمة المجتمع؟ أهمية الار اسة

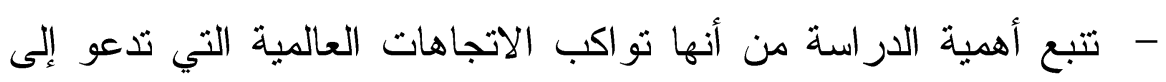

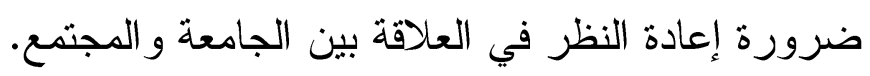
- قد تسهر الدراسة الحالية في إثراء المعرفة النظرية المرتبطة بالحاضنات التكنولوجية وعلاقتها بدور الجامعة في تتمية المجتمع.

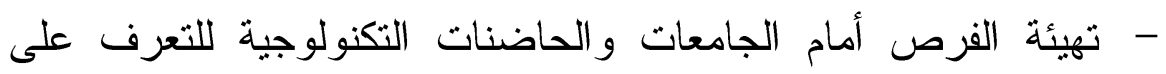

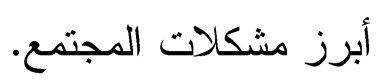


- تشجيع الجامعة على التواجد المستمر والدائم في قطاعات المجتمع

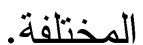

\section{منهج واجر اعات الار اسة}

سوف تعتمد الدراسة الحالية على المنهج الوصفي، وذلك من خلال الإجراءات

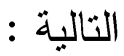

$$
\text { - - تحديد مفاهيم الدر اسة. }
$$

- - عرض الدراسات السابقة المرتبطة بموضوع الدراسة. - رصد مؤشرات عن و اقع دور الجامعة في خدمة المجتمع. - تحديد ماهية الحاضنات التكنولوجية ومبرر ات إنشائها في الجامعات. - تحديد دور الحاضنات التكنولوجية في خدمة المجتمع في بعض الدول. - عرض التصور المقترح على مجموعة من المحكمين.

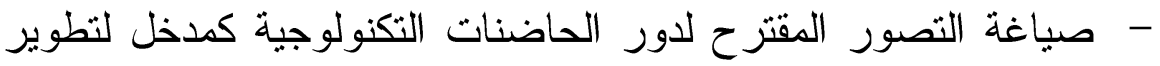
دور التعليم الجامعي في خدمة المجتمع في ضوء تجارب بعض الدول

$$
\text { مفاهيم الدراسةة أولاً : مفهوم التطوير }
$$

إذا كان التطور لغة هو التغير التذريجي الذي يحدث في بنية الكائنات الحية وسلوكها، ويطلق أيضاعلى التغير التدريجى الذى يحدث فى تركيبة المجتمع أو العلاقات أو النظم أو القيم السائدة فيه ( ' ( )

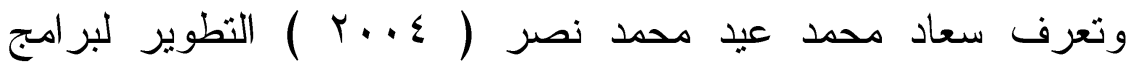
الدراسات العليا على أنه مجموعة التغييرات المقصودة المر اد إدخالها فى أحد أو بعض أو جميع مكونات نظام الدراسات العليا ( برامج الدبلوم الخاص )

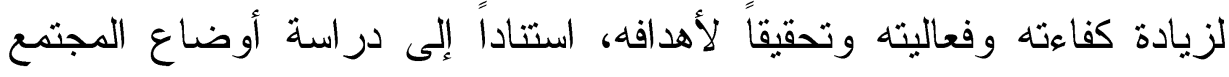
المختلفة و المؤثرات الداخلية و الخارجية المعاصرة و المستقبلية ذات العلاقة به. 
بينما يرى شاكر محمد فتحي ( ب99 ) ) أن النطوير هو عملية تغيير مقصود ومخطط يهدف إلى الارتقاء بالمنظمات المجتمعية على مختلف ألو انها،

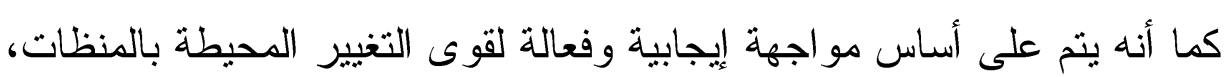

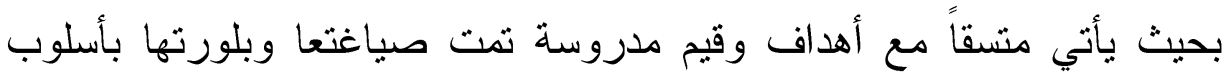

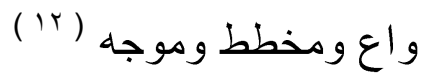

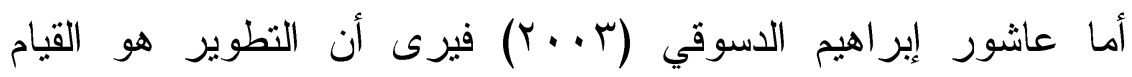
بالتغيير الإيجابي لكل وبعض خواص النظام النعليمي بهدف النمو والارتقاء

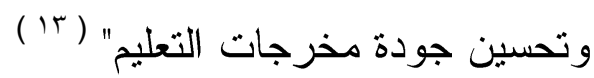

ترى الدراسة الحالية أن مفهوم التطوير يتمثل في جميع الجهود المخططة و المنظمة من أجل احداث تغيير في دور التعليم الجامعي من أجل خدمة المجتمع بهدف المشاركة في التتمية المستدامة وزيادة فاعليته وتتمية كفايات الموارد البشرية عن طريق التّريب و البحث. ثانياً : مفهوم الحاضنات التكنولوجية تزى الدراسة الحالية أن الحاضنات التكنولوجية بالجامعات - سيرد تحديد المفهوم فيما بعد - تعد منظومة متكاملة توفر كافة السبل و التسهيلات لمشروعات قطاعات المجتمع، بداية من مكان مناسب ومجهز بالتجهيزات و الإمكانيات المطلوبة لبدء عمل المشروعات، وشبكة اتصالات برجال الأعمال

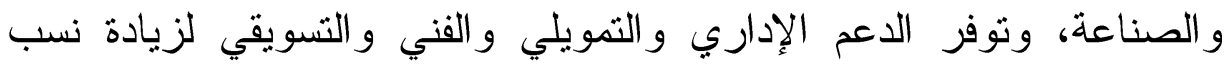
نجاح المشروعات الملتحقة بها، و التخلب على المشكلات التي تو اجهها وتجعلها ولهيا عاجزة عن الوفاء بالتزاماتها بما يعمل على تطوير دور الجامعة في خدمة لهاب المجتمع. 
الار اسات السابقة

أولاً : دراسات ركزت على أهمية الاستثمار في البحث العلمي وعلاقته بخدمة

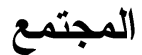

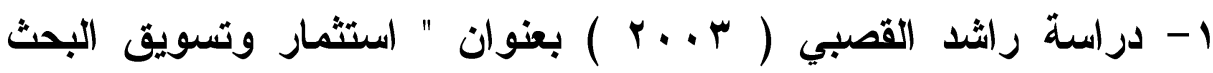

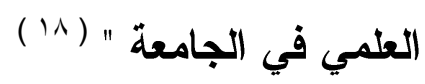

هدفت الدراسة من خلال المنهج الوصفي عرض خبرات بعض الدول

في تطوير واستثمار وتسويق البحث العلمي الذي تتنجه المؤسسات البحثية المختلفة، وعرض لخبرات جامعات بعض الدول في تطوير واستثمار البحث العلمي، وتحديد واقع دور الجامعة في مصر في تطوير واستثمار البحث العلمي

وكان من بين أبرز نتائج الدراسة انخفاض مصادر تمويل البحث العلمي

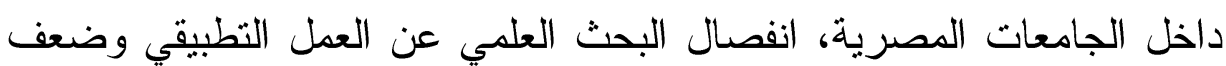
تأثيره في حل مشكلات المجتمع، وضعف الطلب الاجتماعي على نتائج البحوث العلمية في الجامعات المصرية

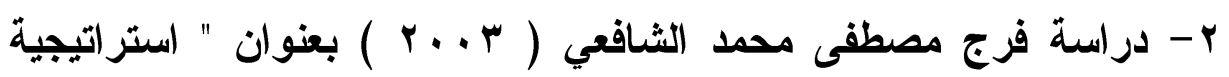
مقترحة لتطوير العلاقة بين البحث العلمي بالجامعات وبعض مؤسئ مؤسمات الإتتاج

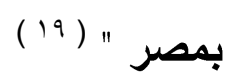

هدفت الدراسة من خلال المنهج الوصفي وأسلوب دلفي إلى بناء

إستر اتيجية جديدة لنطوير العلاقة بين البحث العلمي بالجامعات وبين مؤسسات الإنتاج بمصر، وذلك من خلال : تحليل جوانب العلاقة الحالية بين البحث بلهين

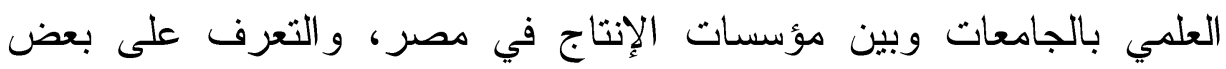
الخبرات العالمية في مجال تطوير العلاقة بين البحث العلمي بالجامعات وبين

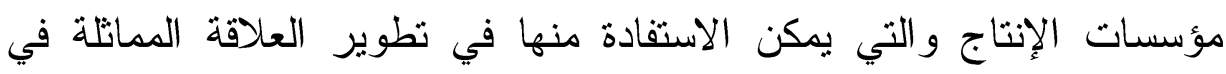

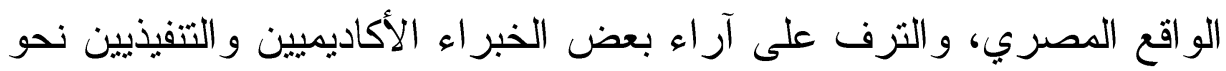


أساليب تطوير هذه العلاقة من خلال خبر اتهم العلمية و العملية والاستفادة من

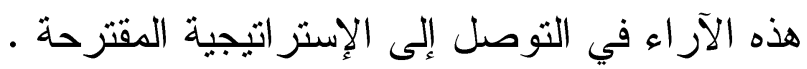

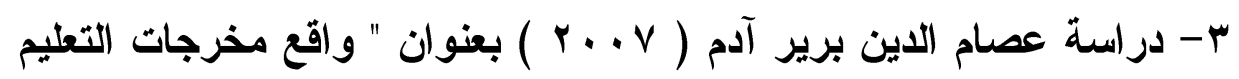

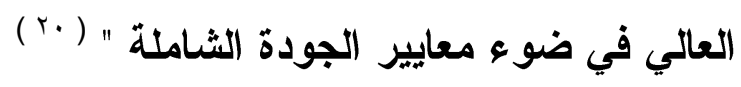

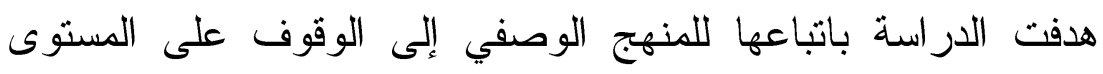

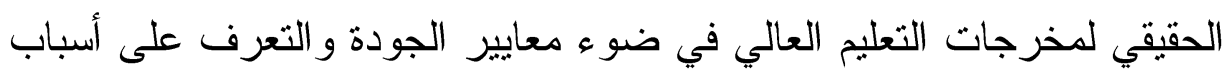

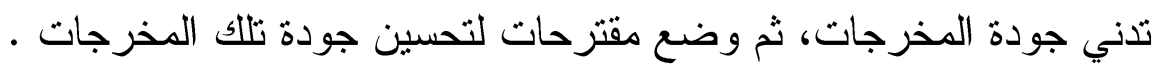
وكان من بين أبرز نتائج الدراسة، إن مخرجات التعليم العالي بوضعهات

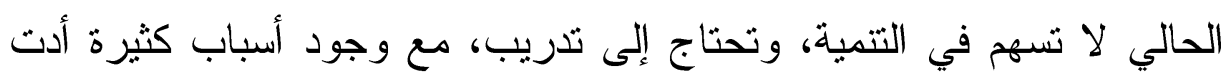

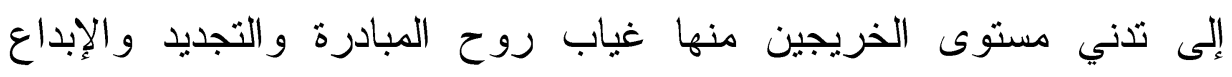
وضعف الإعداد بالجامعات وتقليدية المناهج بالتعليم العالي، والافتقار إلى رونى

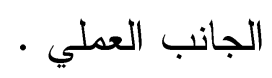
تعقيب على دراسات المحور الأول

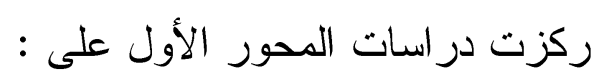

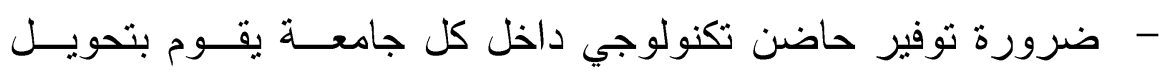

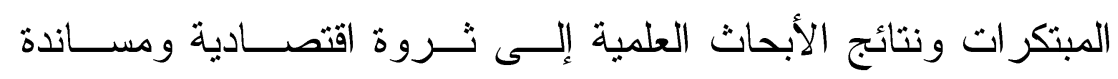

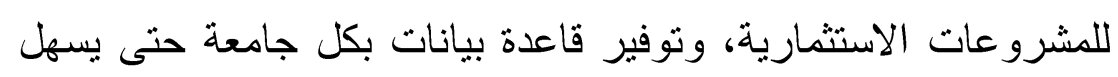
التز ابط بين الجامعات و المؤسسات المختلفة. - مضع خريطة قومية للبحث العلمي و التكنولوجيا يتحقق فيها الربط بين

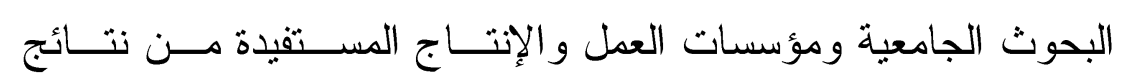

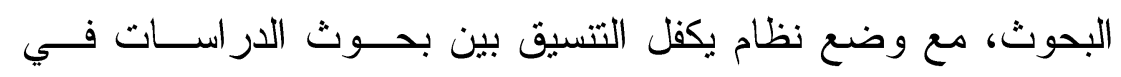

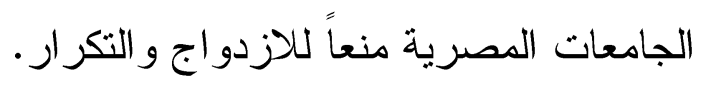

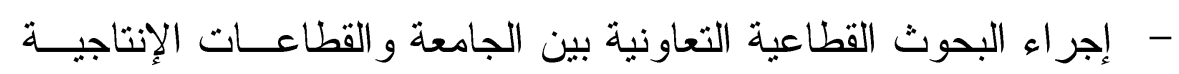

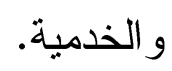


ثانياً : دراسات ركزت على الحاضنات ودورها في خدمة المجتمع

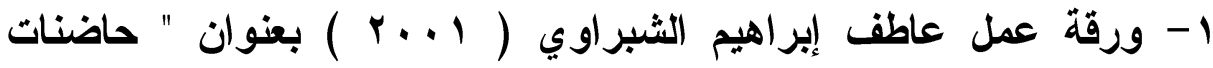
المشروعات الصغيرة والتنمية التكنولوجية - تجربة حاضنة الأعمال التكنولوجية بالتبين " ( (r)

استهدفت هذه الورقة توضيح فلسفة حاضنات الأعمال وخاصة الحاضنات التكنولوجية ودورها في مساعدة أصحاب الأفكار الجيدة والذين لاتتو افر لديهم الموارد الكافية لتحقيق طموحاتهم ومساعدتهم في إقامة وتطوير مشروعاتهم عن طريق توفير بنية متكاملة تقلم خدمات ودعم يؤديان إلى نطور

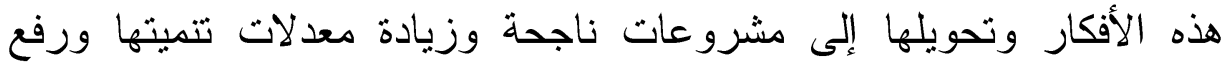
كفاءتها الاقتصادية إلى الحد الذي يضعها على طريق النمو المستمر. ومن خلال تشجيع وتحفيز إقامة مشروعات جديدة وخاصة المشروعات ذات القاعدة

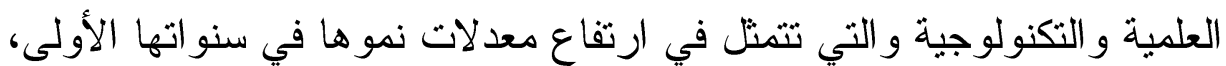
فإن هذه النوعية من حاضنات الأعمال التكنولوجية قد أثبتت نجاحاً كبيراً خاصة في كل من الو لايات المتحدة و إسر ائيل.

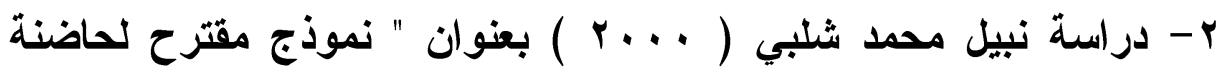

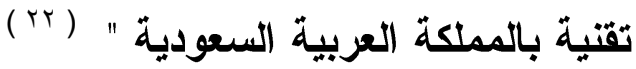
هدفت هذه الورقة إلى تحديد المقصود بحاضنات المشروعات الصغيرة و المتوسطة، وعرض تجربة كل من جمهورية مصر العربية، وتجربة حاضنة أوستن بالولايات المتحدة الأمريكي، ثم وضع ونم نموذج مقترح للحاضنة التكنولوجية وشروط إقامتها و آليات عملها.

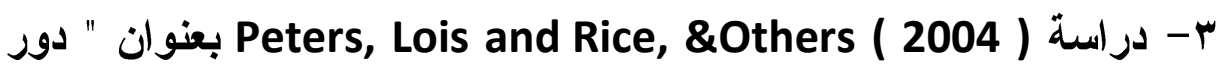

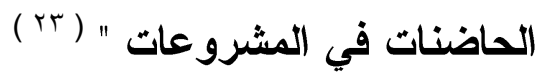
هدفت الدراسة إلى محاولة وضع تصور لدور حاضنات الأعمال في

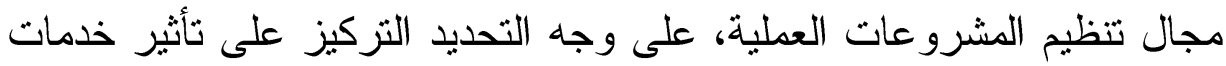


البنية التحتية والتشريب و إنشاء الثبكات المعلوماتية، على معدلات التخرج من الحاضنات التكنولوجية.

وشمل التصور المقترح دور حاضنات الأعمال في توفير الاعم في بدء التشغيل

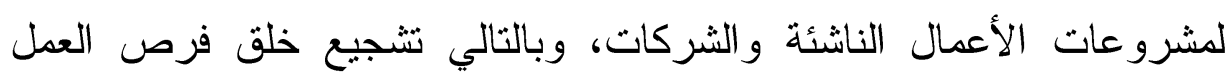

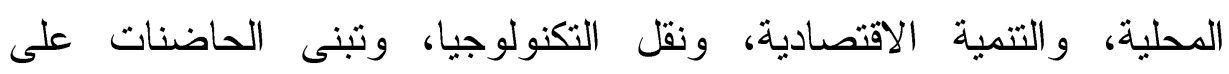

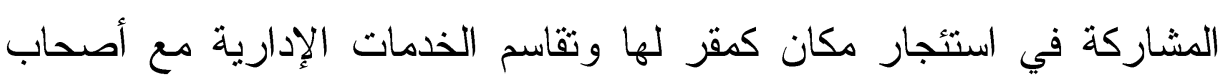

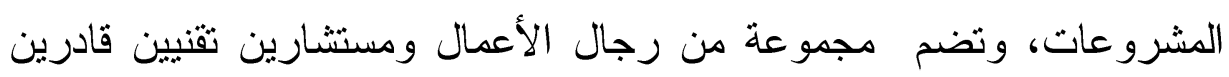

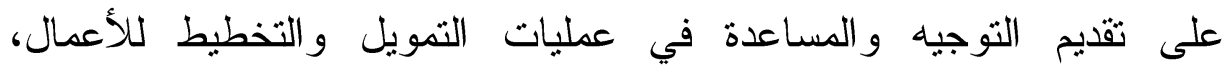
و التسويق، و الاستشار ات القانونية، و التصنيع، الخ.

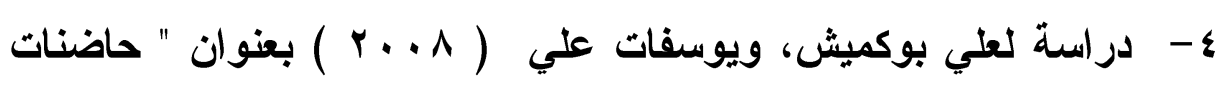

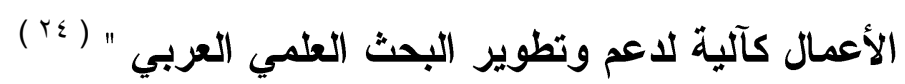

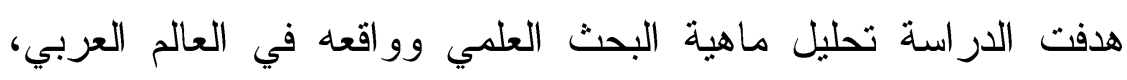

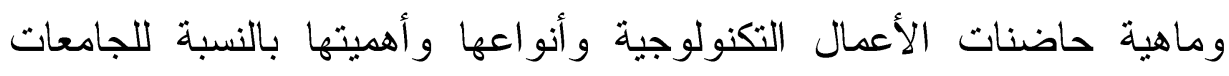

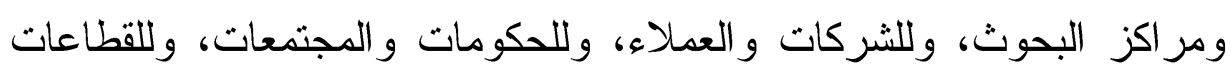

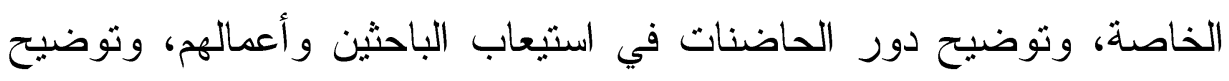
العلاقة بين الحاضنات و اقتصاد المعرفة، مع إبراز أهمية بناء حاضنة أعمال عربية مشتركة.

وكان من بين أبرز توصيات الاراسة التي يمكن أن تسهم في تفعيل

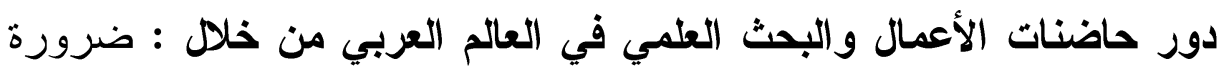

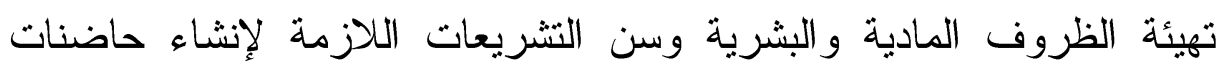

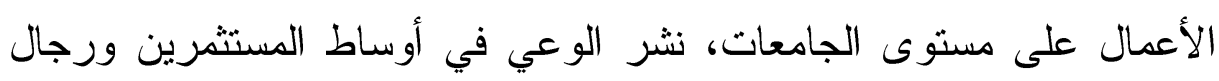

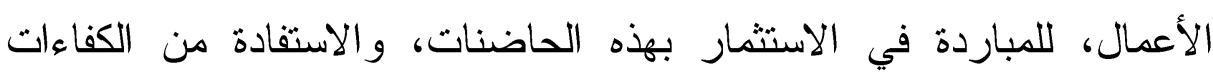
العربية المحلية و المهاجرة من خلال إنشاء حاضنات أعمال عربية ودولية. 


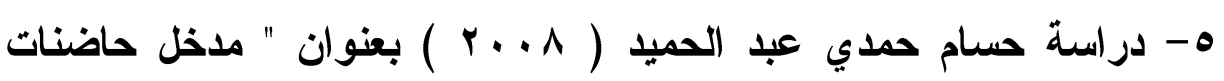
الأعمال لتفعيل العلاقة بين الجامعة وقطاع الأعمال على ضوع قيادة ثقافة التغيير لمايكل فولان... دراسة مقارنة لتجاب دول عربية وأجنبية " (ro )

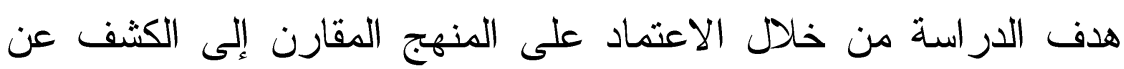

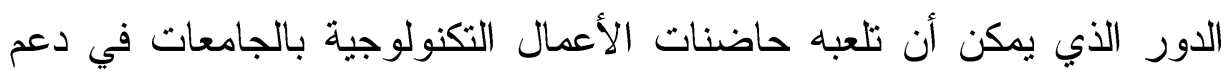

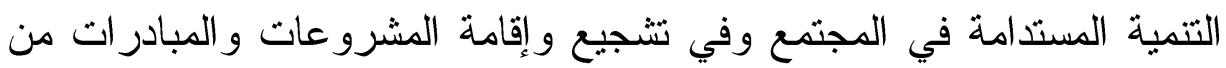

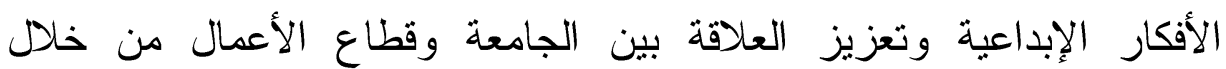
التعرف على ماهية الحاضنات التكنولوجية وتحليل دورها التنموي وتعزيز العلاقة بين الجامعة وقطاع الأعمال وفق لمتطلبات قيادة ثقافة التغيير لمايكل فو لان، وتحليل أبرز التجارب الأجنبية في مجال عمل الحاضنات التكنولوجية، وفئه

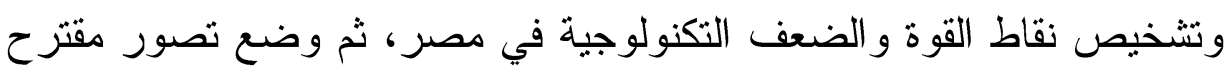

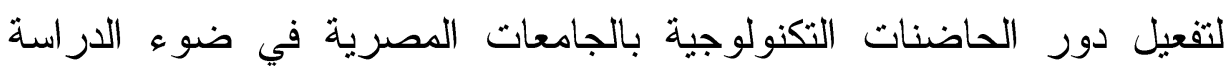

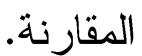

وقد وضعت الدراسة تصور مقترح لتوجه الجامعة في ضوء قيادة ثقافة التغيير لمايكل فولان لتوجه الجامعة نحو الحاضنات التكنولوجية في مصر لاعم التتمية المستدامة في المجتمع وتعزيز العلاقة بين الجامعة وقطاع الأعمال فلابد من نو افر العوامل التالية : - الإدارة الفعالة للحاضنة لتحقيق الهدف الأخلاقي. - - دعم المجتمع وفهم التغيير - - بناء ونشر المعرفة حول انتقاء مشروعات الحاضنة. - - - بناء العلاقات للحصول على التمويل.

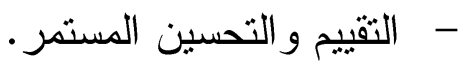

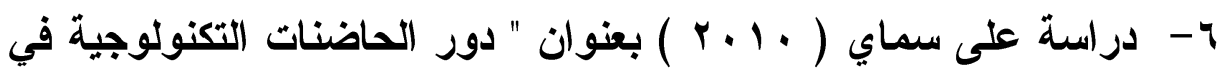

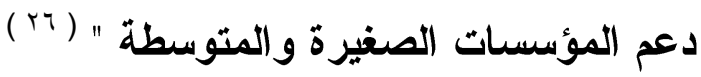


هدفت الدراسة إلى التعرف على حاضنات الأعمال ودورها في دعم المؤسسات الصغيرة و المتوسطة من خلال نوضيح مفهوم حاضنات الأعمال

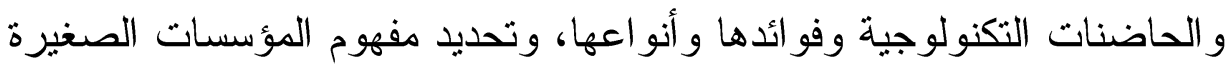

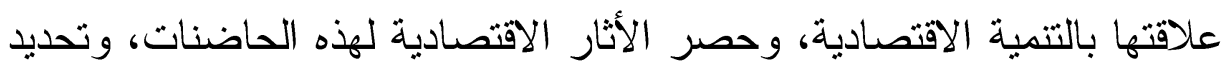

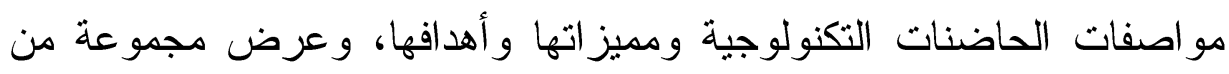

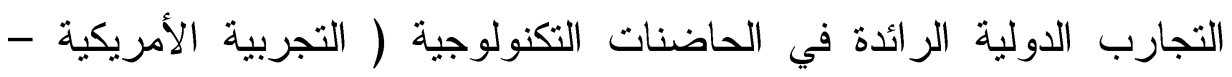

$$
\text { تعقيب على دراسات المحور الثانية - الصينية - السورية ) }
$$

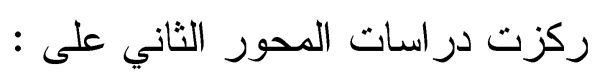

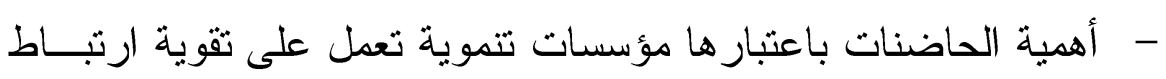
التعليم الجامعي بقطاعات المجتمع المختلفة، وعلى دعم الثباب المبادر

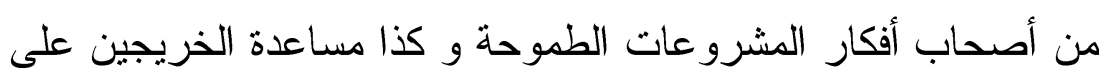

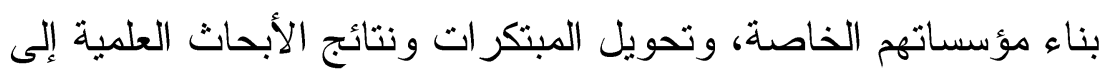

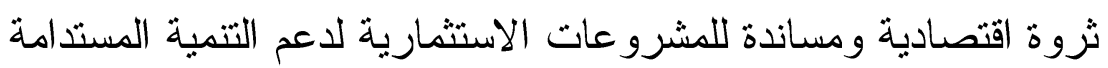

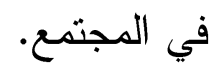

- أهمية الحاضنات في توفير فرص العمل وللحصول على دخل و افر .

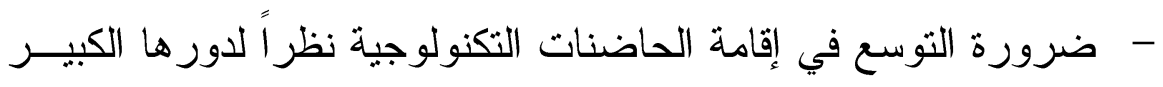
في تحقيق التتمية، ودعم البحث العلمي محلياً وعربياً.

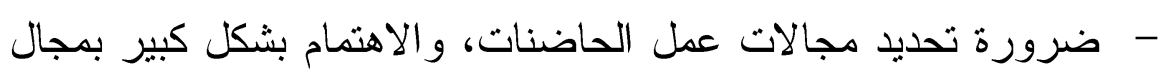

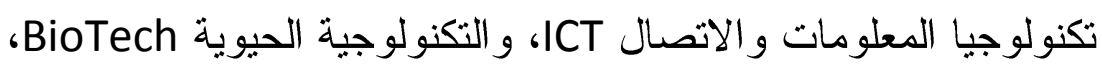
و الطاقات المتجددة، وتقنيات و آليات تحلية المياه، وتكنولوجية تـدوبير النفايات، وتكنولوجيات الزر اعية التي تلائم البيئة. 
ثالثاً : دراسات ركزت على آليات تطوير دور الجامعات في خدمة قطاعات

المجتمع

1- دراسة أنطون رحمة ( ب . . P ) بعنوان " العلاقة التكاملية التنموية بين

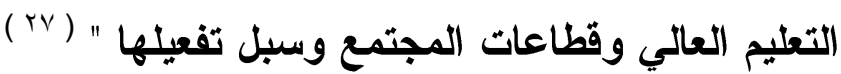

هدفت الدر اسة إلى تحديد واقع العلاقة بين التعليم العـالي وقطاعـات

المجتمع، وسبل تفعيل هذه العلاقة وتوجيهها نحو التكامل التتموي .

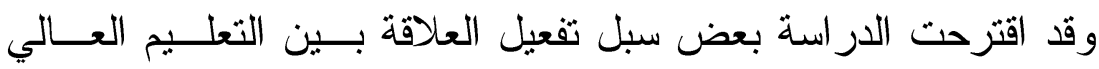

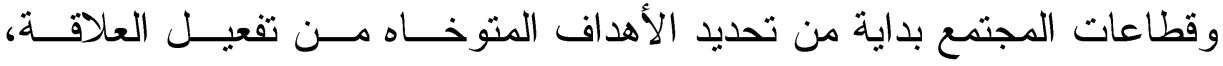

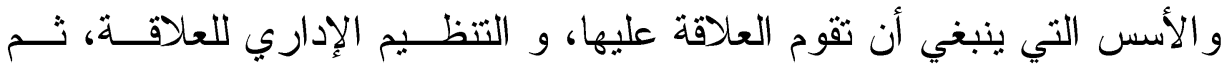
المهمات المشتركة المطلوب القيام بها منها : إجر اء البحوث القطاعية، تبــادل الخبرة والمشورة، تتظيم التعاون بين الطرفين في مجال التدريب، التوفيق بين سياسات القبول وسياسات التشغيل، تتبع خريجي التعليم العالي، الإعلام عـن بر امج التعليم العالي وعن مجالات العمل وفرصــه، المشــاركة فــي إقامـــة

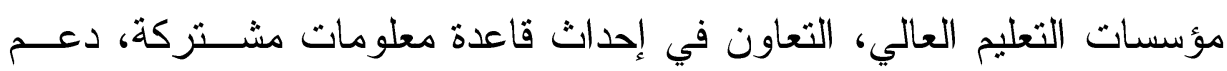

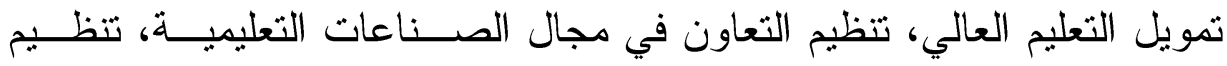
التعاون في توفير التسهيلات، التعاون في إقامة المعارض، تتظيم اللقاءات، ثم وضع خطط تشغيلية للبر امج المشتركة .

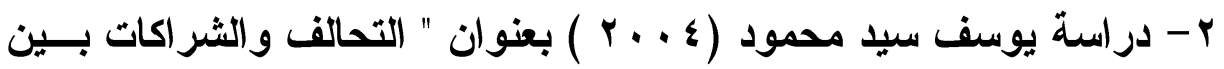

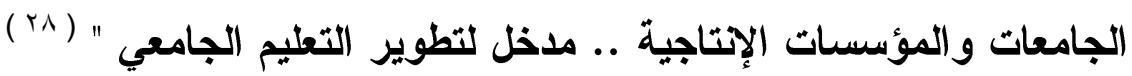
استهدفت الدر اسة تحليل بعض التحديات ذات التأثثر علــى التحالفــات و الثر اكات بين الجامعات و المؤسسات الانتاجية، وعرض لمفاهيم التحالفــات و الشر اكات، ثم عرضت نماذج العلاقات و الثر اكة في بعض الجامعات يمكـن الاستفادة منها في تطوير التعليم الجامعي بمصر .

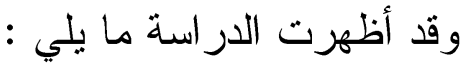


- - بمر اجعة الجهات التي تولت التخطيط و التنفيذ للمشروعات القومية

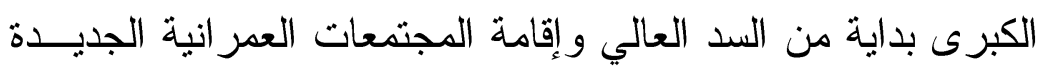

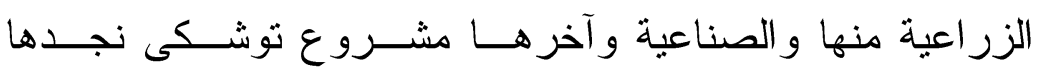

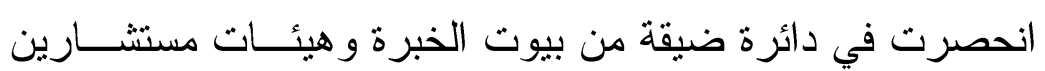

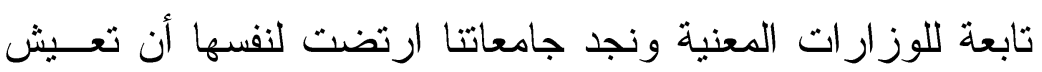
على هامش هذه المشرو عات ولم تبد فيها رأياً.

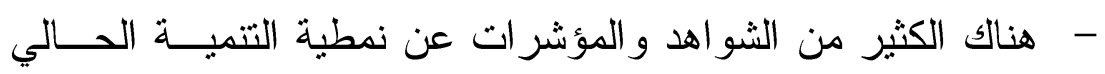

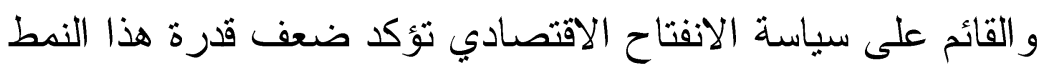
على تحريك العلاقة الساكنة بين الجامعات و المجتمع • تعليق على دراسات المحور الثالث ركزت دراسات هذا المحور على أهمية :

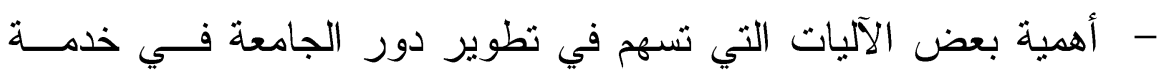

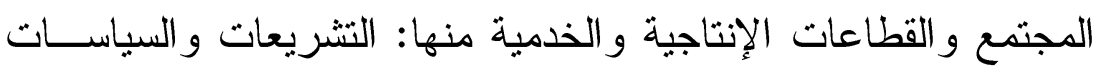

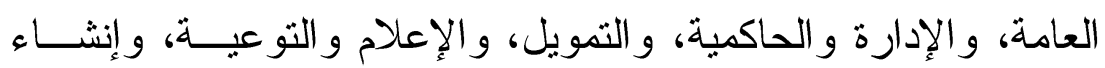

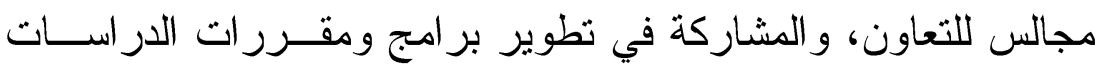
العليا بالجامعات.

\section{تعقيب عام على الاراسات السابقة باته}

- أكدت الدراسات السابقة على ضرورة تطوير دور التعليم الجامعي في خدمة المجتمع لما له من تأثير على عملية التتمية المستدامة في الدولة.

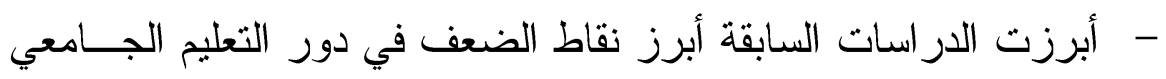

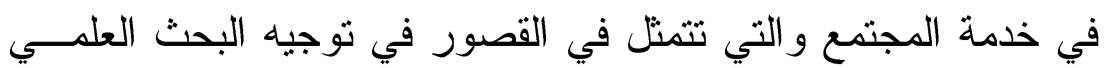

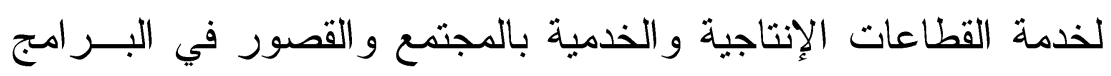
التدريبية التي تقوم بها الجامعة لخدمة المجتمع. 
- ركزت الدراسات السابقة على أهمية إعداد الكوادر البشــرية وأهميـــة

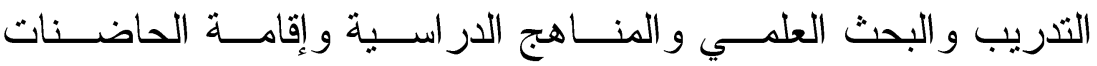

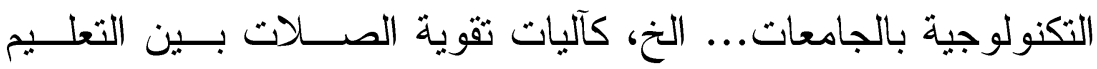

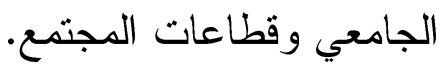

- - استفادت الدراسة الحالية من الدراسات السابقة في كيفية صياغة مشكلة

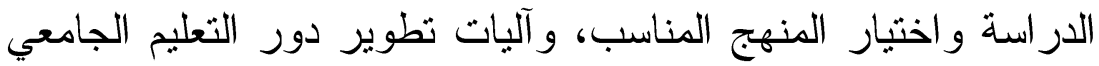

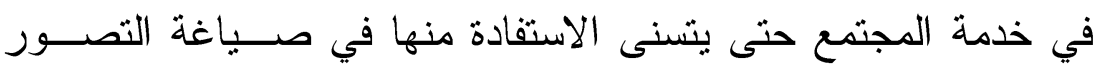
المقتر ح.

بعض المؤشرات عن أبعاد دور الجامعة في خدمة المجتمع

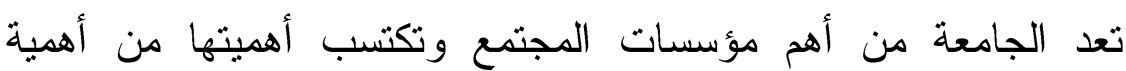
الوظائف التى تؤديها، وكلما تحققت هذه الوظائف بصورة مناسبة، كان المردود

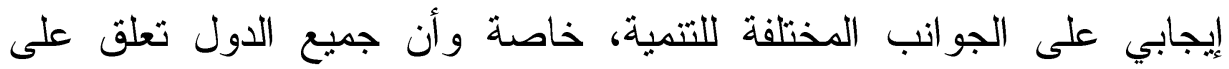
التعليم الجامعى أهمية كبيرة لاجتياز مراحل النمو لتحقيق الرقي والتقدم

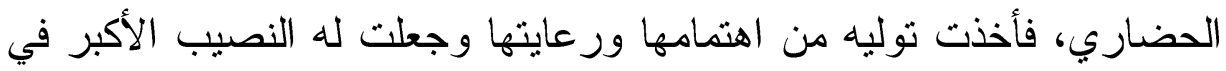
الخطط التتمية وتهتم بإعادة النظر في جميع مدخلاته من أجل الاستجابة

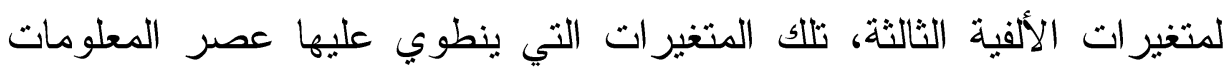
و التي يري البعض أنها ستحدث هزات عنبفة في مدخلات النظام التعليمي ككل

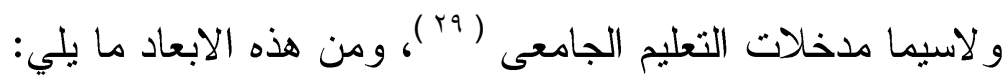
1- البحث العلمي وخدمة المجتمع

يقوم البحث العلمي بدور كبير في تطوير المجتمع وتقدمه، حيث أن

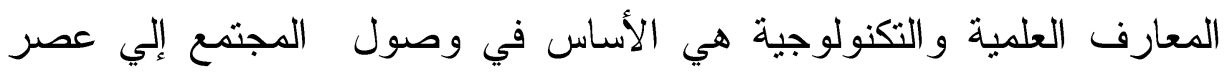
الثورة الرقمية، ولعل السبيل إلي الوصول إلي هذا العصر الرقمي لن يكون إلا ولا

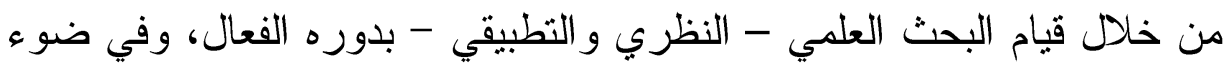
ما يشهده المجتمع من تحولات جذرية في شتي أنواع المعرفة، يصبح التجديد 
في بنية البحث العلمي أمراً ضروريا، بحيث يكون التعليم الجامعي منتجا

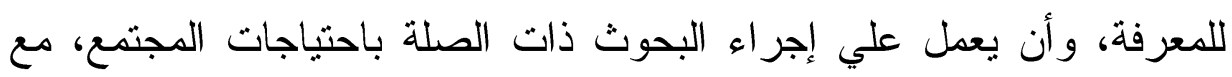

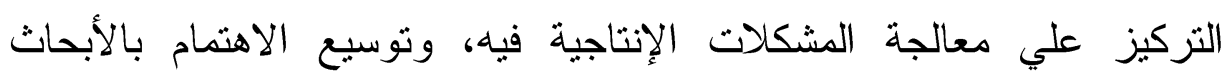
النطبيقية والاستفادة من تكنولوجيا المعلومات في تطوير مهام البحث العلمي لهيكي بشكل يتتاسب ومجتمع المعرفة، وفيما يلي مؤشرات عن و اقع البحث العلمي: أ - عدم مساهمة البحث العلمي في عملية التنمية وحل مشكلات المجتمع وفئم إن الربط الوثيق بين مؤسسات التعليم الجامعي و البحث العلمي و التطوير

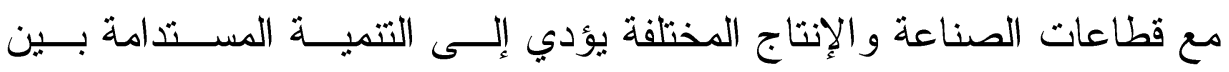

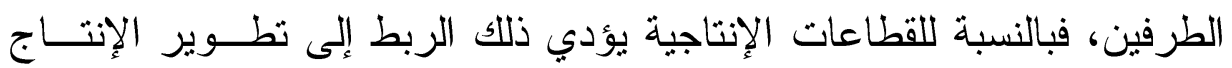

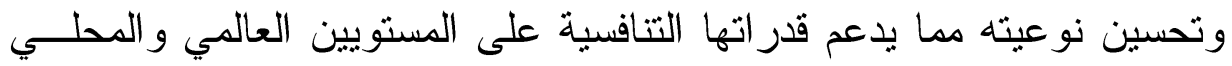

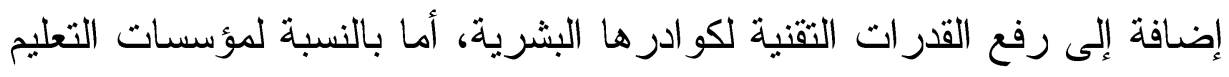

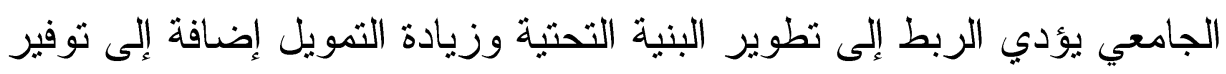

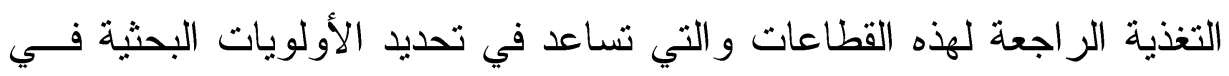
هذه المؤسسات

فالبحث العلمي يعد رافد لعملية التتمية الاقتصادية والاجتماعية، وتعد

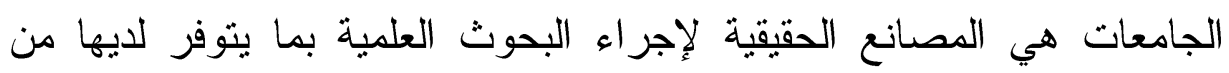
كفاءات بشرية وتجهيزات ومكتبات متخصصة ومناخ علمي متميز. إلا إنه

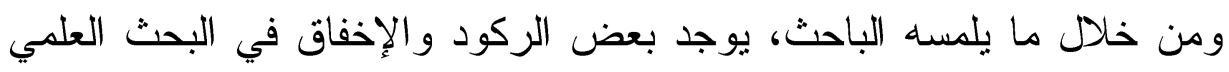

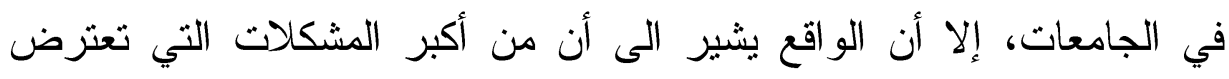
تتمية البحث العلمي في الجامعات هي الحاجة إلى تتمية الإدر الك و الفهم المتبادل بين رجال الجامعات من جهة وبين القائمين على شئون الإنتاج في مواقع العمل لإدئ

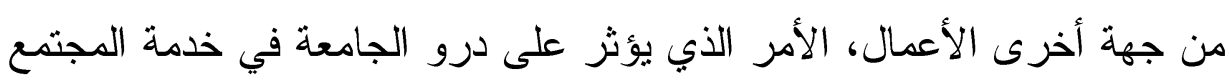

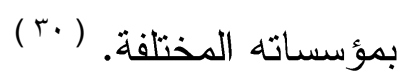


بالاضافة الى غياب مفهوم صناعة البحث والتطوير في مجتمع البحث العلمي المصري، وبالتالي لم يكن له دور حيوي في توليد تكنولوجيا محلية

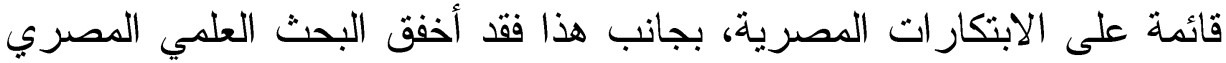
في إرساء قو اعد الهندسة العكسية لإنتاج التكنولوجيا، ومن هذا المنطلق صعب

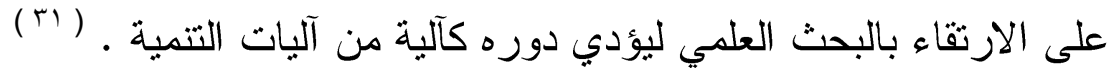

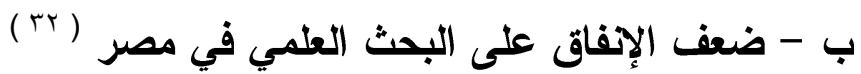

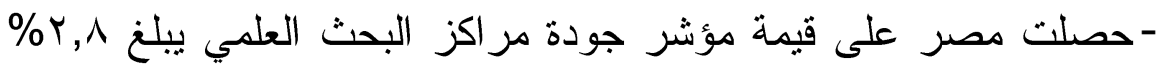

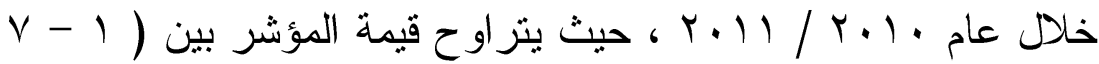
) حيث يعبر الواحد عن التدني التام في مستوى مر اكز البحث العلمي، وتعبر V عن التميز التام في مستوى مراكز البحث العلمي واحتلت مصر المرتبة با || من بين r\& ا دولة على مستوى العالم، وبذلك تعد مصر دولة طاردة وغير جاذبة للعقول -بلغت نسبة الانفاق الحكومي على البحث العلمي r, • \% من ون الناتج المحلي

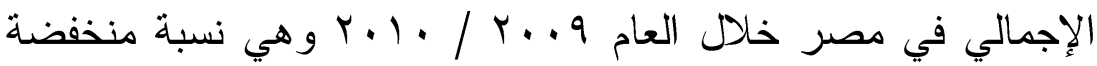

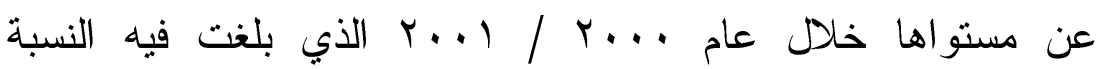
$\% \cdot, Y T$

-بلغت نسبة الإنفاق الحكومي على البحث العلمي ^؟ب, •\% من الإنفاق

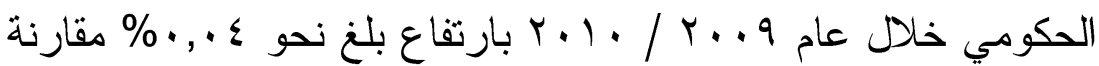

$$
\text { بالعام السابق }
$$

- ارتفاع إجمالي الاعتمادات المالية المخصصة للبحث العلمي بالموازنة

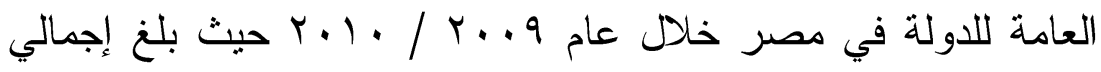

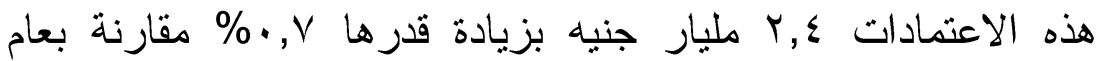
(rr) r.. $9 /$ / . . A 
-يمثل التمويل الحكومي 99,9\% من إجمالي تمويل أنشطة البحث العلمي

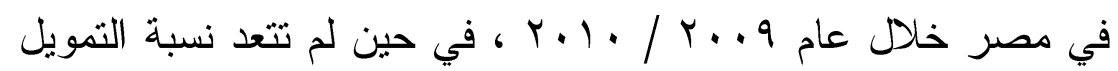

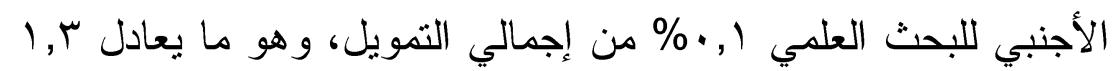

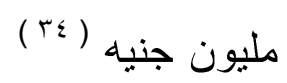

-بلغ عدد براءة اختراع بـ أصدها مكتب براءعات الاختراع المصري

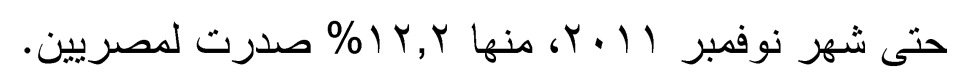

هذه المؤشرات تؤكد ضعف الإنفاق على البحث العلمي في مصر نتيجة غياب دوره الحقيقي في تتمية المجتمع وضعف التعاون بين الجامعات وقطاعات الإنتاج و الخدمات

\section{r - تقديم الطلاب و العاملين بقطاعات المجتمع}

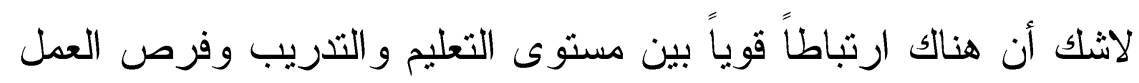

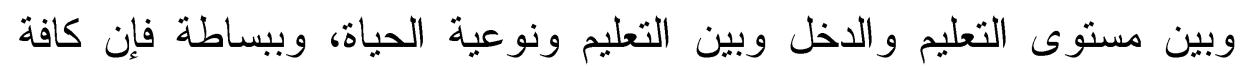

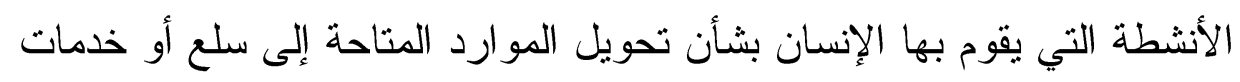
يحتاج إليها الإنسان في حياته اليومية تستند إلى قدر معين من المعرفة و المهارة

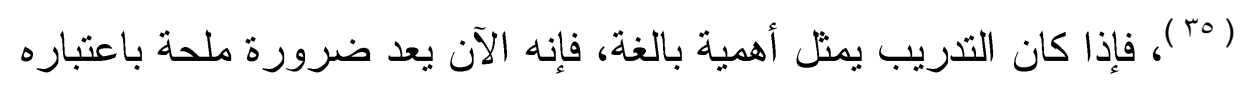

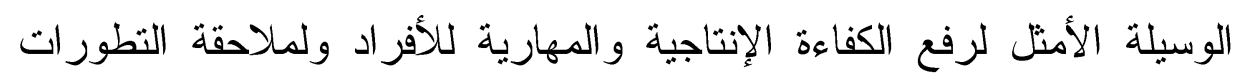
التكنولوجية و العلمية ولتتمية روح التعاون وربط الفرد بالمجتمع وسوق العمل.

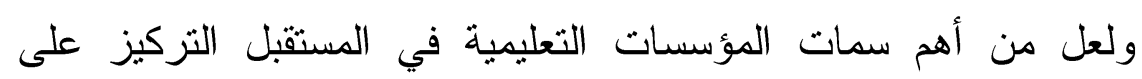

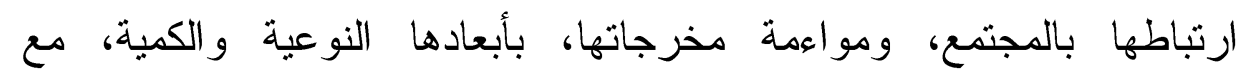

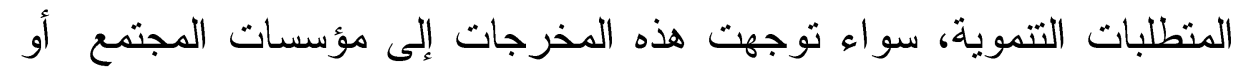
إلى مراحل تعليمية أخرى. وهكذا تؤدّى المؤسسة التعليمية والتدريبية دورها هوهات

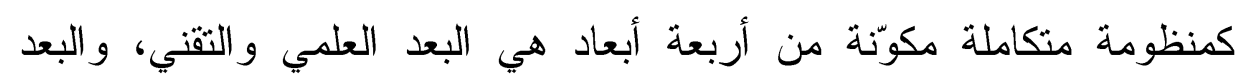

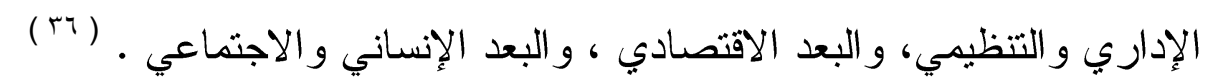


وبالرغم من أن الترريب يرتبط ارتباطاً مباشراً بالتعليم ويعد عنصراً

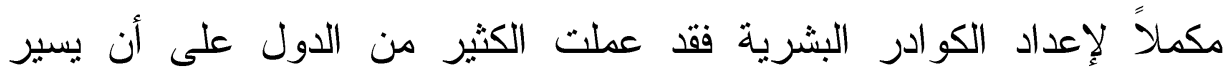

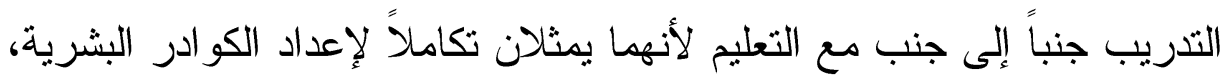

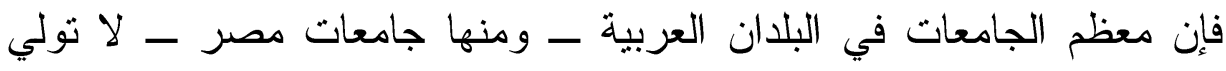
اهتماماً بتأهيل خريجيها على الوظائف المتاحة بالسوق لعدة أسباب من بينها :

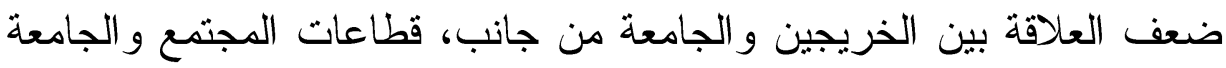
من جانب آخر • وفي المقابل تتجه معظم المؤسسات الكبرى في المجتمع في وني معظم البلدان على إنثاء مر اكز تدريبية متخصصة داخل هذه المؤسسات

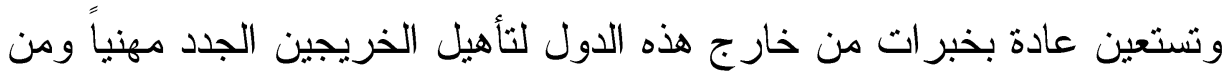
ثم إعادة تأهيلهر على متطلبات الوظائف التي ستسند إليهم ـ (

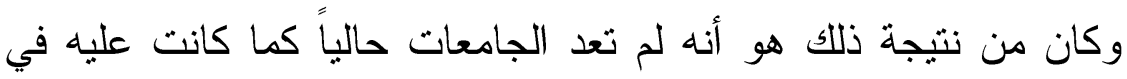
الماضي، حيث لم تكن لديها القدرة على أداء المهام و المسؤوليات المناطة بها لتحقيق أهداف المجتمع وطموحت مواطنيه، و أصبحت في مكانة متو اضعة جداً لاتساعدها على مواكبة التحولات و التحديات السريعة والمتلاحقة التي يعيشها

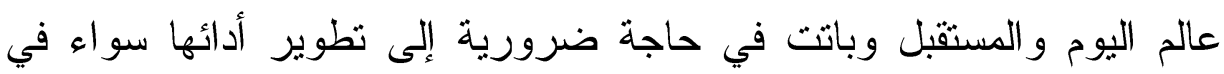

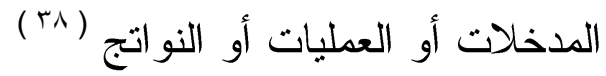
بناءً على ماسبق يمكن القول بأن حيث يلاحظ أن التعليم الجـامعي فــي

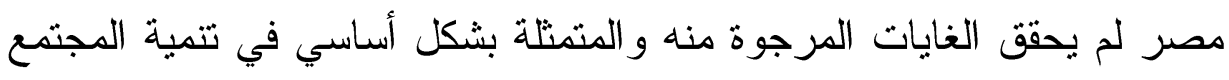

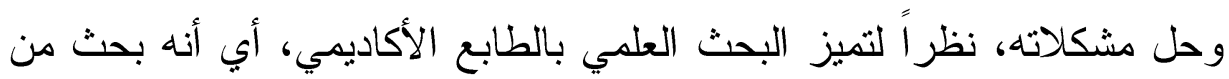

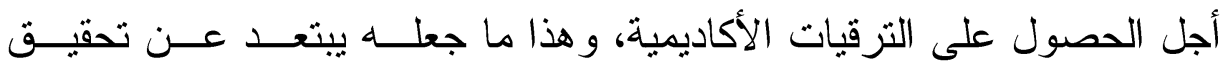
طموحات المجتمع وتتميته، هذا إلى جانب غياب العلاقة التفاعلية و الارتباطية

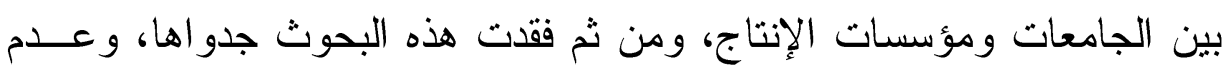
وضوح الرؤية لدى القطاعات الإنتاجية بالدور الذي يمكن أن تسهر به البحوث

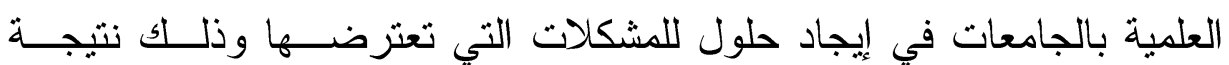




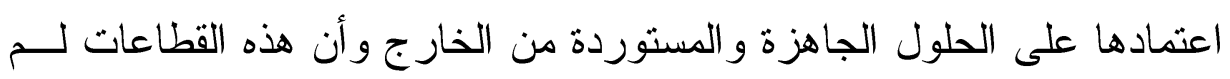

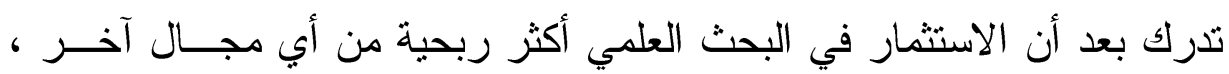

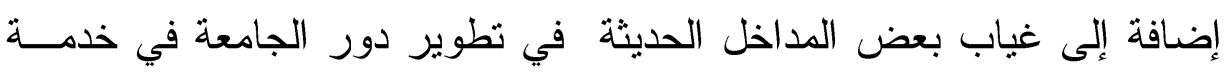

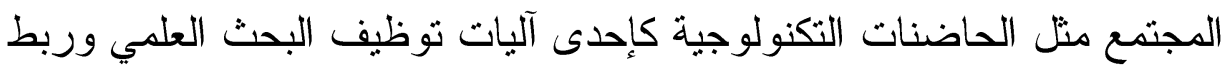
الجامعات بالقطاع الاقتصادي وبالمجتمع.

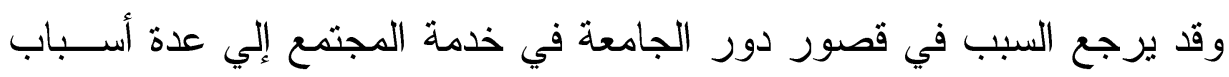
من بينها:

- عدم تبني الأساليب الحديثة مثل الحاضنات التكنولوجية في تطوير دور الجامعة في خدمة المجتمع. - غياب المشاركة الحقيقية بين مؤسسات التعلــيم الجــامعي وقطاعـات المجتمع. - غياب خطة حقيقية للبحث العلمي تستند إلى احتياجـات الدولــة مـنـ التنمية. - الأعباء الكثيرة الملقاة على عاتق أعضاء هيئة التدريس وتقـــ عقبــة دون خدمة المجتمع.

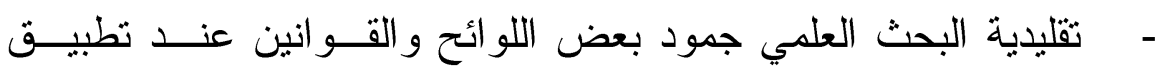
وتجريب بعض البحوث في خدمة المجنمع.

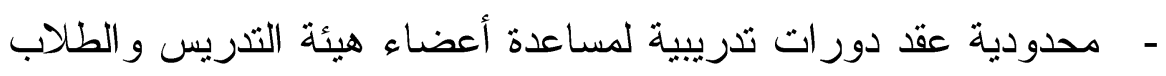

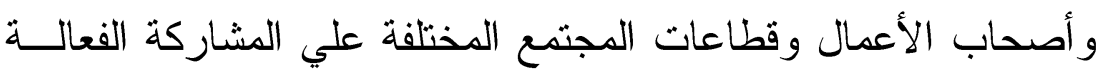

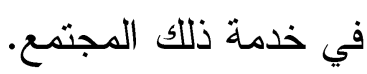
ثانياً : الحاضنات التكنولوجية ... مفهومها وتاريخها ومبررات إنشائها

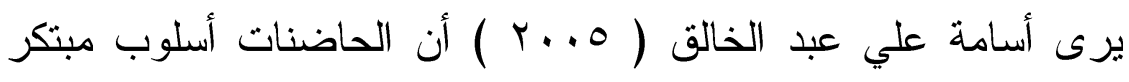
لتبنى المشروعات حيث ينظر إلى كل مشروع وكأنه وليد يحتاج إلى الرعاية

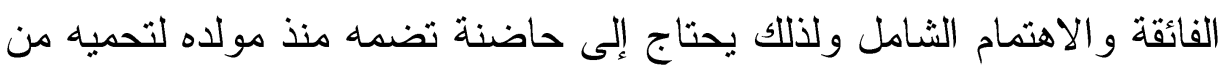


مخاطر المشروعات وتمده بطاقة الاستمر ارية وتدفع به تدريجيًا بعد ذلك قويًا

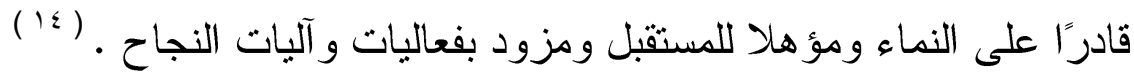
بينما تعرفها العين وجدان التلهوني الساكت ( ب. . . م ) على أنها مركز أعمال يقدم حزمة متكاملة من الخدمات الإدارية ويوفر المواقع والأجهزة اللازمة ويقدم الخبرة التقنية و العملية لصاحبات الأعمال للتغلب على المعوقات التهات

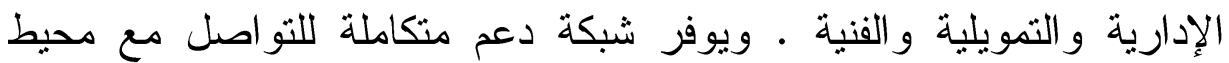
الأعمال وتقديم المشورة . (10) بينما برى حسام حمدي عبد الحميد ( r... ) أن الحاضنات التكنولوجية هي الآلية المطلوبة لدعم التنمية المستدامة وتفعيل العلاقة بين الجامعة وقطاع الأعمال وبالتالي هي ضرورة ملحة وتساوي في قيمتها الدور

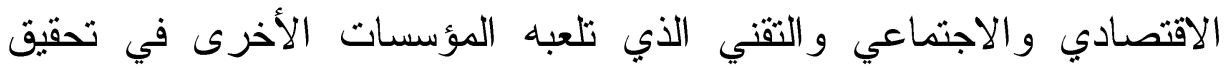
التنمية المستدامة ـ (14) و هناك من عرفها بأنها عبارة عن وعاء صغير يقام فى حيز صغير

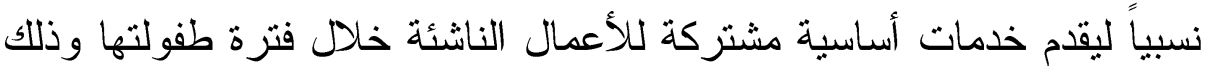
فى مجالات الإدارة والتكنولوجيا و المعلومات و الإرشاد ليسهل على المشرو عات

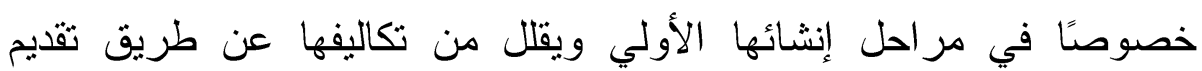

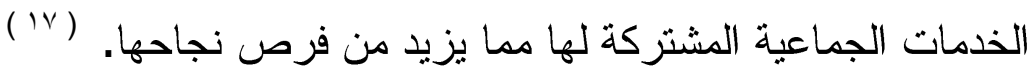

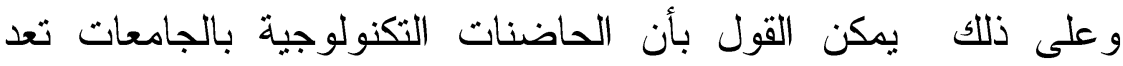

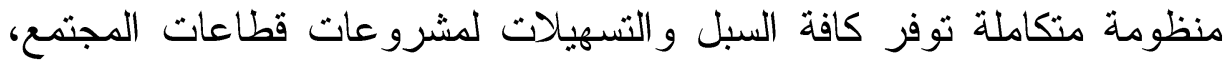
بداية من مكان مناسب ومجزز بالتجهيزات والإمكانيات المطلوبة لبدء عمل المشروعات، وشبكة اتصالات برجال الأعمال والصناعة، وتوفر الدعم الإداري و التمويلي و الفني و التسويقي لزيادة نسب نجاح المشروعات الملتحقة بها، والتغلب على الشكلات التي تواجهها وتجعلها عاجزة عن الوفاء بالتز اماتها بما يعمل على تطوير دور الجامعة في خدمة المجتمع. 


\section{تاريخ الحاضنات التكنولوجية}

تمت البداية الحقيقية لانتشار مفهوم الحاضنات في الثمانينيات وتحديداً

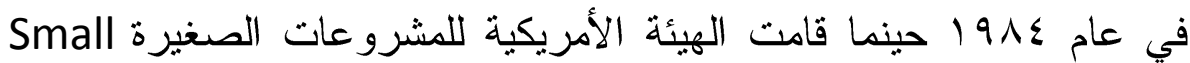
Business Administration (SBA )

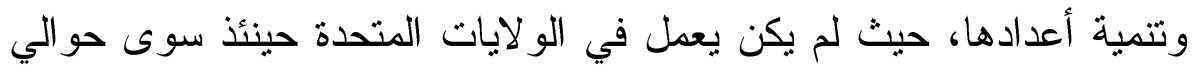
• r حاضنة، ثم ارتفع عدد هذه الحاضنات بشكل كبير عند قيام الجمعية National Business Incubator الأمريكية لحاضنات الأعمال Association (NBIA ) بعض رجال الصناعة الأمريكيين في صورة مؤسسة خاصة تهدف إلى تتشيط تتظيم صناعة الحاضنات، وفي نهاية عام 1999 وصل وصل عدد الحاضنات في الولايات المتحدة إلى حوالي ..1 حاضنة، وذلك من خلد

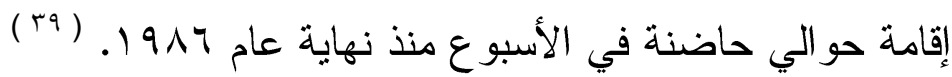
أنواع الحاضنات

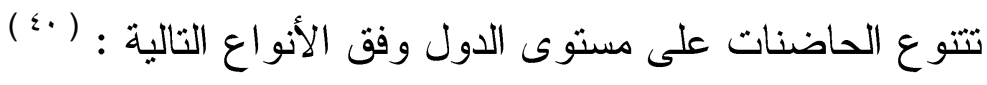
1-حاضنة المشروعات العامة غير التكنولوجية، وهي تلك الحاضنة التي تتعامل مع المشروعات الصغيرة ذات التخصصات المختلفة والمتتوعة في كل المجالات الإنتاجية والصناعية والخدمية دون تحديد مستوى تكنولوجي لهذه المشروعات، وتركز في جذب مشروعات الأعمال

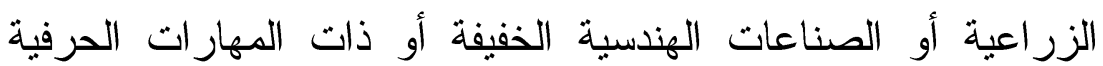

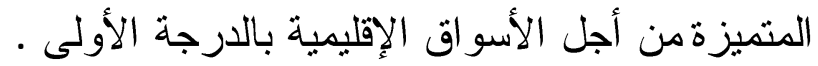

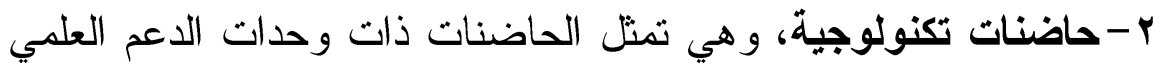

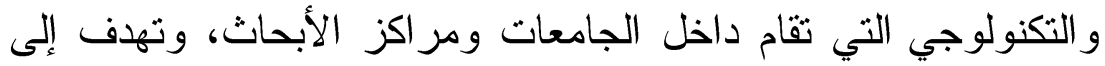

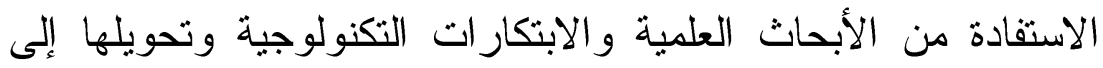
مشروعات ناجحة، من خلال الاعتماد على البنية الأساسية لهذه 
الجامعات، من معامل وورش وأجززة بحوث، إضافة إلى أعضاء

هيئة التدريس و الباحثين و العاملين كالخبر اء في مجالاتهم. ومن خلال وهل

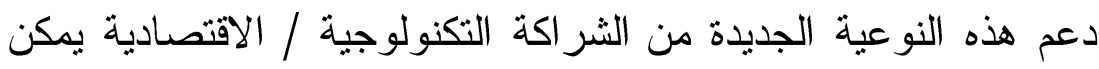
إعادة تعريف الدور الذي يمكن أن تلعبه المعاهد البحثية و الجامعات في هي البه

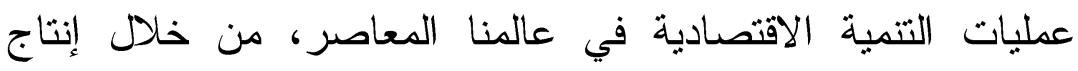
وتسويق التكنولوجيات الجديدة و المتطورة .

rncubators without الحاضنات المفتوحة أو حاضنات بدون جدران

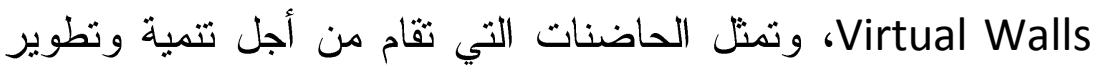
المشروعات و الصناعات القائمة بالفعل، حيث تقام في أماكن التجمعات الصناعية لتعمل كمركز متكامل لخدمة ودعم المشروعات المحيطة، وتقوم الحاضنات المفتوحة بجميع أنشطة حاضنات المشروعات التقليدية، من حيث العمل كجهة وسيطة بين المشروعات، والمراكز البحثية و الجامعات، ومعامل الأبحاث، ومر اجعة الجودة و والجهات

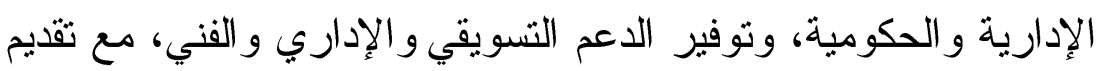
الاستشار ات اللازمة لنمو المشروعات .

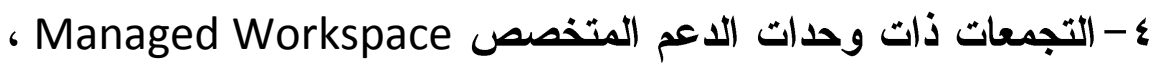

هي منظومة متكاملة من الأعمال ذات الصبغة الصناعية صمدت بشكل يساهم في تتمية صناعات محددة عن طريق توفير البيئة والبنية

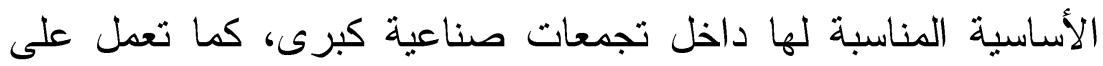
خدمة تلك التجمعات و إمدادها بالصناعات المغذية لها حسب طبيعة موقعه، وتتشابه مع الحاضنات التقليدية في تواجد إدارة مركزية وخدمات مشتركة، إلا أنها قد لا تشترط معايير خاصة للمشروعات

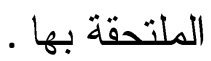




\section{الخدمات التي تقدمها الحاضنات التكنولوجية}

تقدم الحاضنة حزمة متكاملة من الخدمات التي ترتبط مباشرة

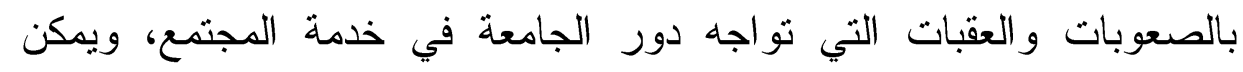

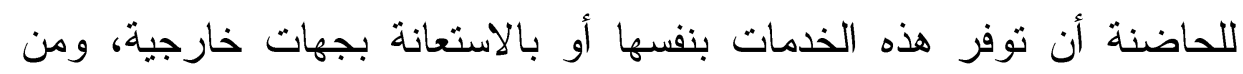

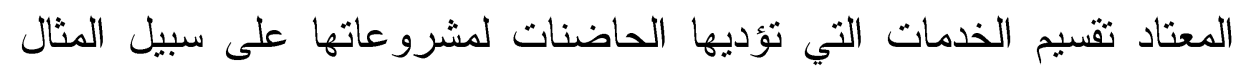
(إلى : (1)

• خمات إدارية : خطة عمل، تدريب مهارات إدارية، أعمال سكرتارية،

$$
\text { خدمات إنترنت، خدمات فاكس وكمبيوتر ... الخ. }
$$

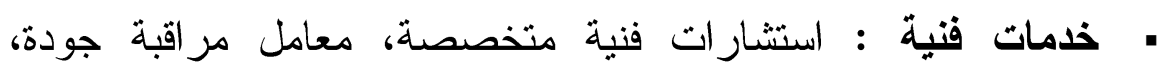

$$
\text { تدريبات فنية ... الخ. }
$$

• خدمات مالية : قروض الصندوق الاجتماعي، دراسات الجدوى،

$$
\text { مستندات مالية، ...الخ. }
$$

• خدمات تسويقية : دعاية و المشاركة في المعارض المحلية والعالمية

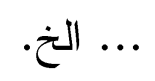

\section{مبررات إنشاء الحاضنات التكنولوجية}

يوجد عديد من العوامل التي تقف وراء إنشاء الحاضنات التكنولوجية،

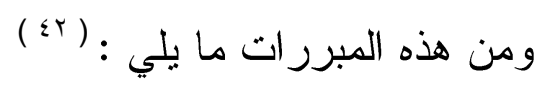

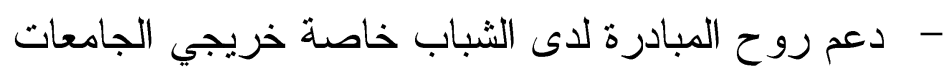

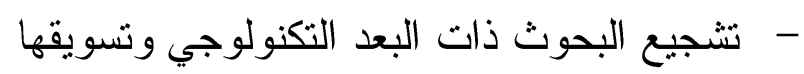

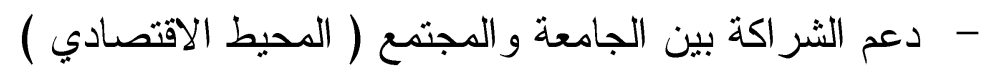
- البحث عن فرص تعاون وشر اكة دولية

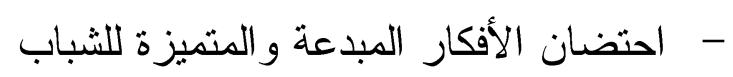
- المساهمة في توفير الفرص المستمرة للتطوير الذاتي - الارتقاء بمستوى الثقانة و التأهيل المستمر في مجال الثقنية 
- - ضمان الاستفادة الفعالة من الموارد البشرية الخلاقة - - المساهمة في صنع المجتمع المعلوماتي - توليد فرص عمل للشباب

- - تسويق المخرجات العلمية و التقنية المبتكرة - - منع هجرة الأدمغة وتوطين التقانة

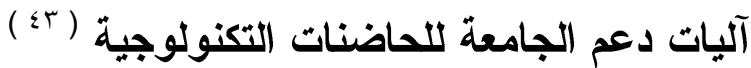

- الاستعانة بالأمثلة الريادية لتوضيح أهمية مفهوم الاختراع (صناعة رواد الأعمال)

- الطلاب وتسهيل عملية الاستفادة المتبادلة بين الطرفين

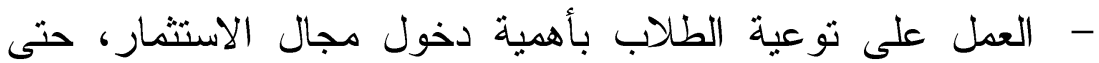
يمكنه القيام بتتفيذ أفكار هم

- عدد محدود من الطلاب الجامعيين يتجهون لمجال الاستثمار، بينما

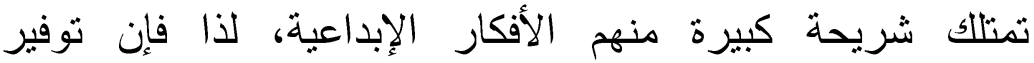
المختصين في مجال الاستثمار وخبر اء إعداد خطط العمل سوف

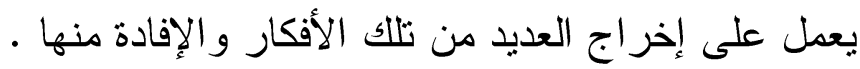
- يرغب كثير من الطلاب العمل في مجال تحقيق أفكار هم نتيجة نقص الخبرة والثقافة في مجال الاستثمار و التي تعد المعوق الأول لاقتحامهم ذللك المجال، فكان و لابد من تقديم الدعم الفني و الاستشاري ( من قبل مجموعة من المتخصصين ) لمساعدة الثباب على تتفيذ مشاريعهم عن طريق برامج، محاضرات وندوات تدريبية، ودورات قصبيرة لإكساب مهارات مهنية 
الحاضنات التكنولوجية وخدمة المجتمع

على الرغم من أن الحاضنات ليست بالابتكار التكنولوجي الوحيد بل هناك

عدة أنواع وأدوات مستحدثة أخرى مثل مدن التكنولوجيا Technopoles،

Centers of حدائق البحوث Research parks، ومراكز التميّز Excellence High-Technology Industry Clusters Technology والحاضنات التكنولوجية Technology Corridors Incubators

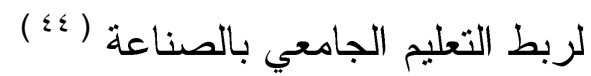
وتعد كذلك حدائق العلوم science-parks شكل من أشكال الحاضنات التكنولوجية التي يتم التركيز فيها على تتمية العلوم و التكنولوجيا وتأمين شر اكات فنية و علمية ودولية ونقل العلم والتكنولوجيا للبيئة الإنتاجية المحلية و إيصال نتائج البحث العلمي إلى السوق أو التجمع العلمي، وتخضع ونه هذه الحدائق لسلطة وزارة التعليم العالي والبحث العلمي والتكنولوجي إضافة لعضوية الجهات

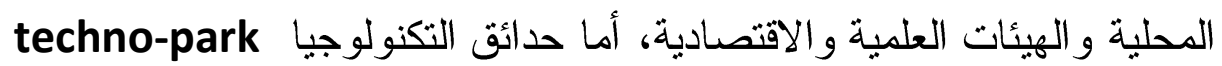
فهي شكل آخر من أشكال الحاضنات التكنولوجية يتم التركيز فيها على ابتكار تكنولوجيات و عمليات وتتظبمات جديدة، وتلعب دور اً حاسماً في تطوير الصناعة لتصبح ذات قدرة تتافسية عالية على صعيد التكنولوجيا والجودة وهو أثبه

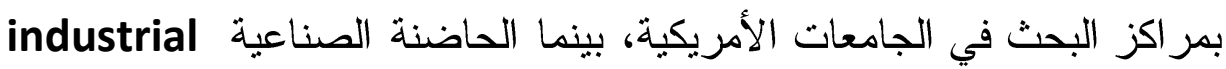
incubator المنطقة من الصناعات الداعمة والمساندة حيث يتم تبادل المنافع بين المصانع الكبيرة في المدينة الصناعية من جهة و المشاريع الصغيرة المنتسبة للحاضنة

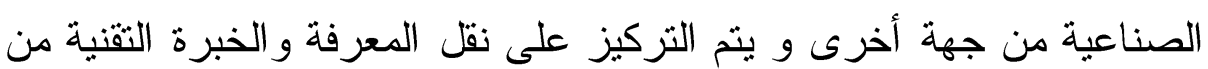

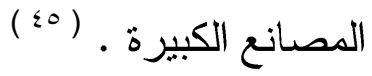


و على هذا فإن تتطلق فلسفة الحاضنات التكنولوجية من كونها مجال يتيح لأصحاب الأعمال و المشروعات استخدام التكنولوجيا المتطورة التي تساعدهم على تأسيس وإدارة واستدامة مشروعاتهم، إلى التركيز على إعداد الموارد

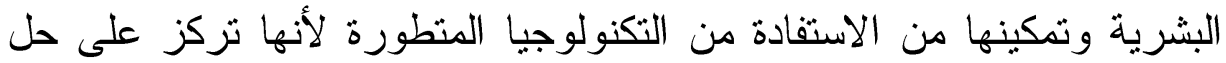

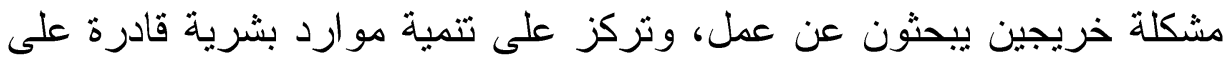

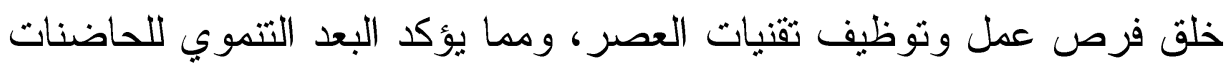
التكنولوجية كونها تتعامل مع المشروعات الصغيرة والابتكارات التكنولوجية

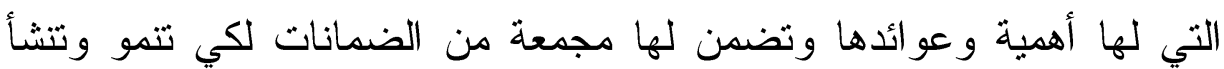

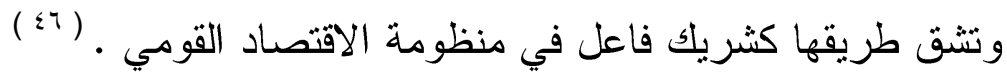
وبناءً على ما تقدم يمكن القول بأن الحاضنات التكنولوجية تعمل على فئل - دعم جهود التتمية الاقتصادية و الاجتماعية و التكنولوجية - - خلق بيئة فعالة محلياً و إقليمياً - إخخال الوطن في نطاق الدول المصنعة للتكنولوجيا - توفر بيئة خصبة للحد من نزيف العقول المصرية - مواجهة الاستبعاد المتعدد من قبل الدول الكبرى في صناعة التكنولوجيا

دور الحاضنات التكنولوجية في خدمة المجتمع في بعض الدول أولاً : التجربة الأمريكية

يرجع تاريخ الحاضنات إلى أول مشروع تم إقامته في مركز التصــنيع المعروف باسم Batavia في ولاية نيويورك في الولايات المتحدة، وذلك عام

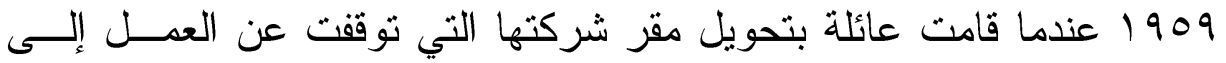

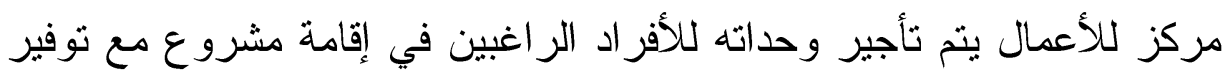

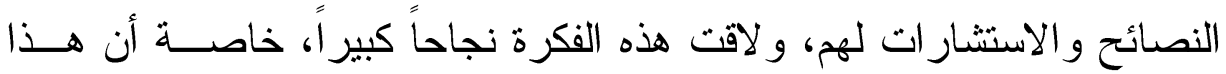

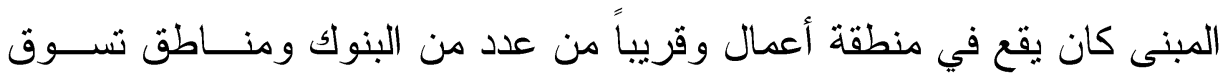




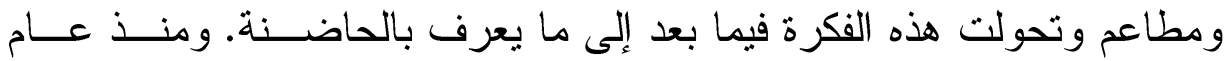

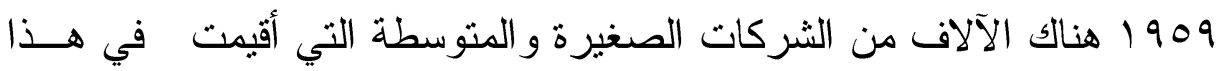

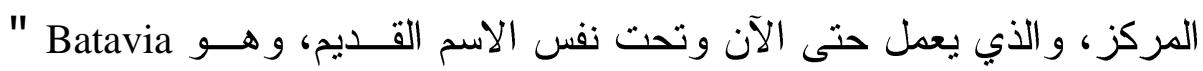
. ${ }^{(\varepsilon \vee}$ Industrial Center "

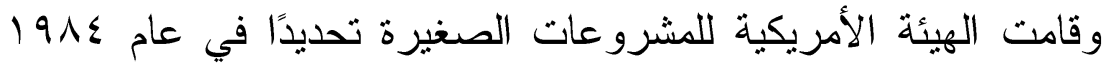
بالاهتمام ببرامج إقامة الحاضنات وتتمية أعدادها، حيث لم يكن يعمل في المديه

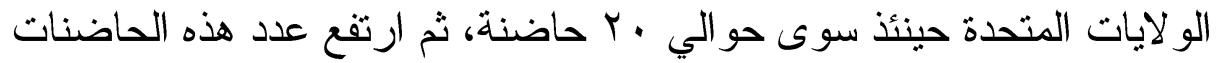

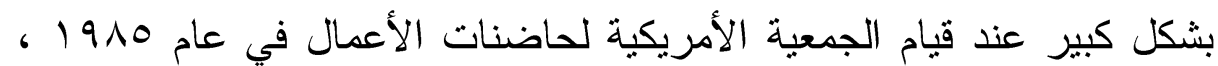

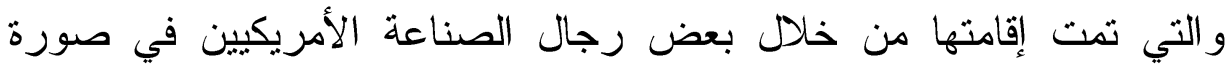
مؤسسة خاصة تهدف إلى تتشيط تنظيم صناعة الحاضنات، وفي نهاية عام 1999 199 وصل عدد الحاضنات في الولايات المتحدة إلى حو الي . .1 حاضنة، وذلك من خلال إقامة حو الي حاضنة في الأسبوع كمعدل منذ نهاية عام 1917 بالإضافة إلى وجود الجمعية القومية لحاضنات الأعمال في الولايات المتحدة، و هي تمثل الثبكة القومية للحاضنات، يوجد عدد من شبكات الحاضنات الإقليمية في الولايات المختلفة، نذكر منها على سبيل المثال : جمعية تكساس لحاضنات الأعمال، وشبكة حاضنات و لاية نيوجرسي، إلخ. وتذكر إحصائيات

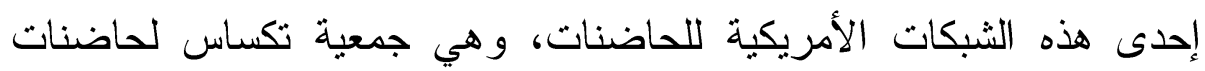
الأعمال، أن معدل نجاح المشروعات الجديدة داخل الحاضنات المرتبطة بهذه وهيه

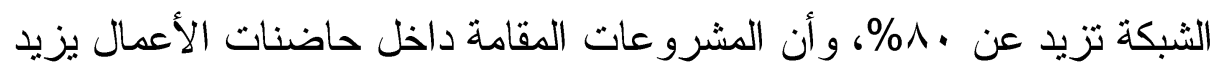
معدل نموها من V إلى Y Y ضعف معدلات نمو المشروعات المقامة خارج حاضنات الأعمال، حيث تم إنشاء 19 ألف شركة جديدة ما زالت الت تعمل بنجاح، ونم خلق أكثر من ب0 ألف فرصة عمل دائمة، وفي إحدى الإحصائيات الحديثة التي تصدرها الجمعية القومية لحاضنات الأعمال عن خصائص 
الحاضنات في الو لايات المتحدة، نجد تحليلا كاملا لسمات هذه الحاضنات تبعاً

لعدة عناصر هي كالآتي: (1)

- موقع الحاضنات : تتوزع حاضنات المشروعات، جغرافياً، على هئ

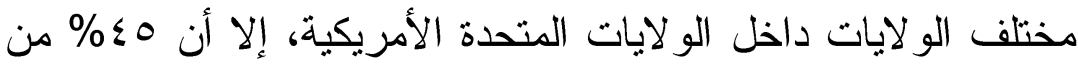

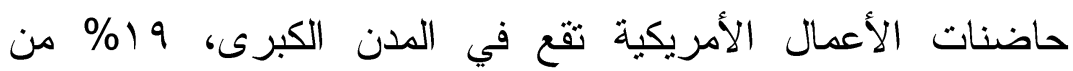

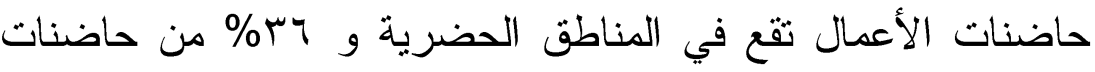
الأعمال تقع في المناطق الريفية. - مساحات الحاضنات : تختلف مساحات هذه الحاضنات ما بين كا بألف ألف متز مربع في أكبرها، وتبلغ متوسط مساحتها القابلة للتأجير لأصحاب

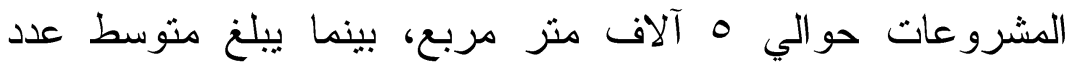
المشرو عات التي تلتحق بالحاضنة الو احدة حو الي · ب مشروعًا.

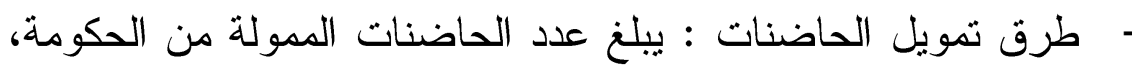
"حاضنات لا تهدف إلى الربح"، حو الي ل1\% من من مجموع الحاضنات، و هي حاضنات تهدف فقط إلى تتشيط التنمية الاقتصادية في المجتمعات المحيطة .بينما تمثل حاضنات الأعمال الخاصة التي ينولى إقامتها وتمويلها جهات خاصة أو مستثرون أو مجموعة شركات صناعية، حو الي ^^ من حاضنات الأعمال في أمريكا، وتهدف هذه النوعية من

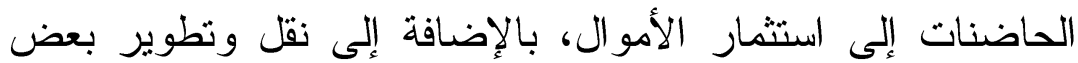

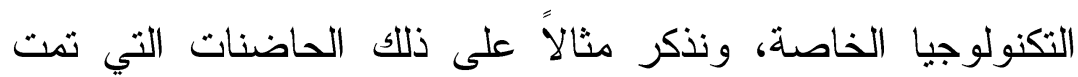
إقامتها من خلال وكالة ناسا للفضاء والخاصة بأبحاث الإككترونيات وتقنيات الاتصالات الحديثة والمنطورة 0\% من الحاضنات تمولها بعض الهيئات الخاصة مثل مجموعة الكنائس الأمريكية، أو جمعيات

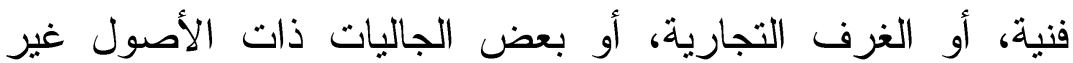

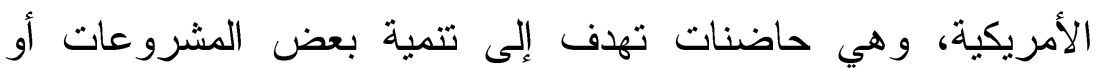




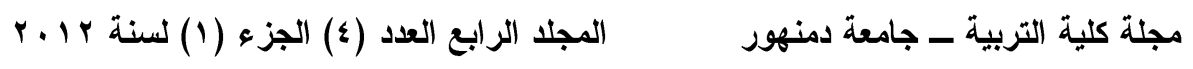

الصناعات التقليدية المتخصصة، أو نوفير فرص عمل لفئات اجتماعية محدة.

- أنو اع وتخصصات الحاضنات : يلاحظ أن بrV من مجموع حاضنات الأعمال داخل الولايات المتحدة الأمريكية هي حاضنات تكنولوجية

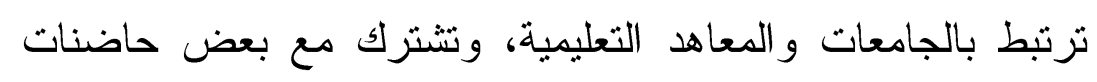

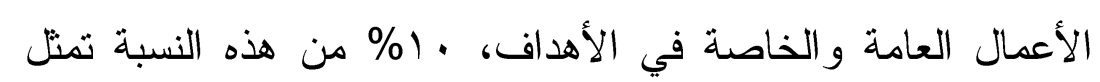

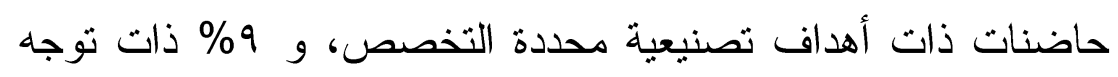
تكنولوجي متخصص ( التكنولوجيا الحيوية، تكنولوجيا المعلومات ) ) ، و 7 \% من مجموع حاضنات الأعمال بالو لايات المتحدة الأمريكية تعتبر من النوع المشترك، حيث يشترك في تمويلها المنظمات غير بل

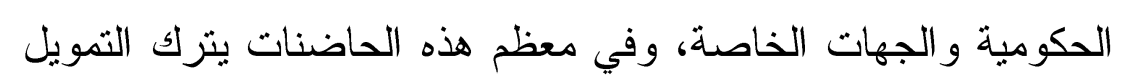

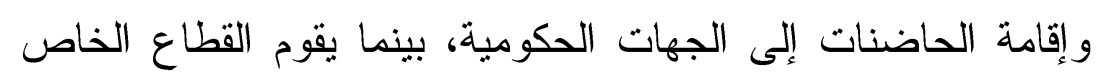

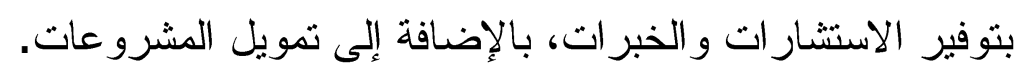
ثانياً : تجربة الصين

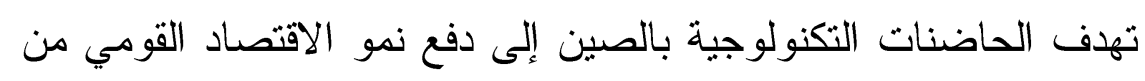

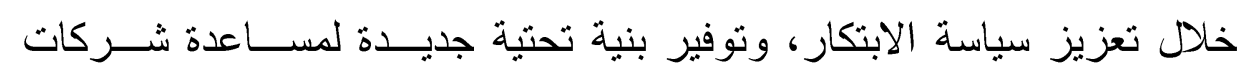

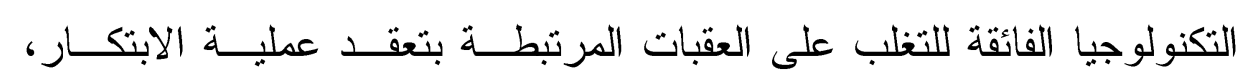

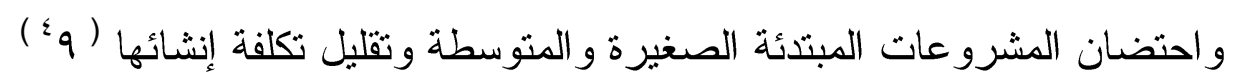
وتقوم الحاضنات التكنولوجية بتقديم خدمات متعددة منها فتح مختبر اتها،

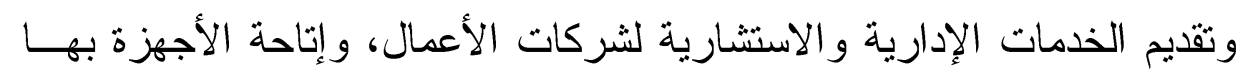

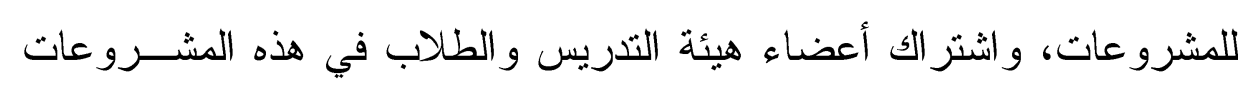

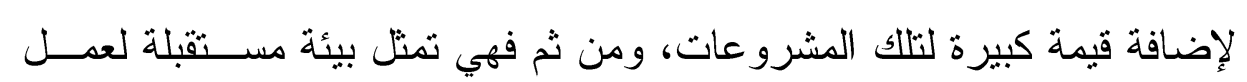

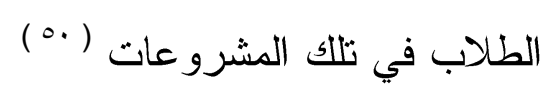


وتقوم الحاضنات التكنولوجية بالتعاون مع أصحاب الأعمال في الصــين

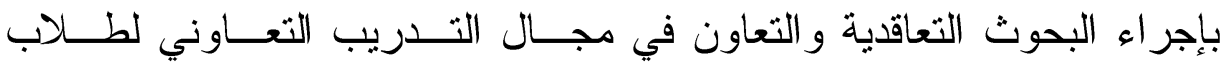
الجامعات، والتعليم المهني، وتقديم الخدمات الاستشارية، وعقد ندوات وحلقات

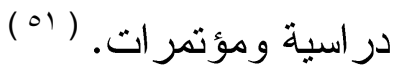
ثالثاً : تجربة جمهورية مصؤية العربة العربية

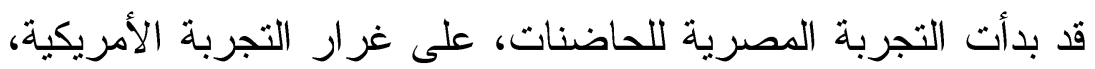
بإقامة هيئة مركزية تقوم بالتخطيط و التتسيق و التتفيذ على المستوي القومي، بدي، وذلك بالشكل الذي يضمن تعظيم وتتمية الموارد البشرية و الكو ادر التي يمكن أن تقوم بإقامة و إدارة هذه الحاضنات ـ لذا فقد تم تكوين الجمعية المصرية لحاضنات الأعمال من نخبة من كبار رجال الأعمال وعدد من الوهاه الوزراء السابقين و أصحاب الخبرات الطويلة في إقامة و إدارة الشركات الناجحة، وتم إثهار الجمعية في يوليو عام 1990 بهدف دعم ومساندة رواد الأعمال و المشروعات الصغيرة في تصميم وتتفيذ آليات تسمح بتقديم كافة الخدمات

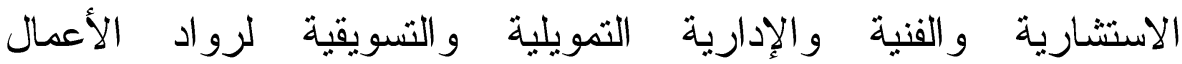
ومشروعاته، وذللك من أجل خلق وتوفير مناخ مناسب لنمو المشروعات الاتد الصغيرة. هذا وتقوم الجمعية المصرية لحاضنات الأعمال بإقامة وتأهيل و إدارة حاضنات الأعمال المختلفة في مصر، وعدد من الدول العربية منذ عام V991، حيث يعود تاريخ التجربة المصرية للحاضنات إلى تاريخ إقامة الجمعية المصرية للحاضنات الأعمال، و التي وضعت أسس خطة استر اتيجية لإقامة عدد من الحاضنات و التجمعات ذات وحدات دعم تكنولوجي و علمي وصناعي في عدد من محافظات جمهورية مصر العربية، من خلال خطة زمنية محددة وبدعم من الصندوق الاجتماعي للتمية الذي يقوم بدور ريادي في إقامة الحاضنات في مصر. هذا بالإضافة إلى قيام وزارة الاتصالات و المعلومات بإقامة أولى الحاضنات التكنولوجية المتخصصة في تكنولوجيا 


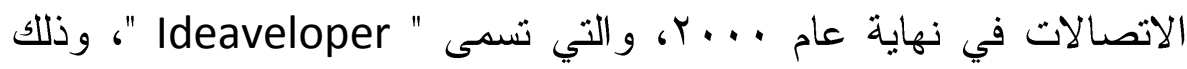

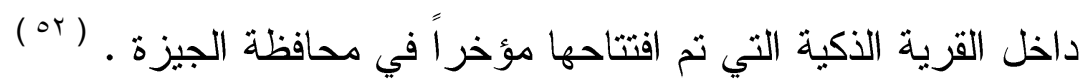

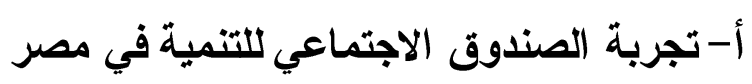

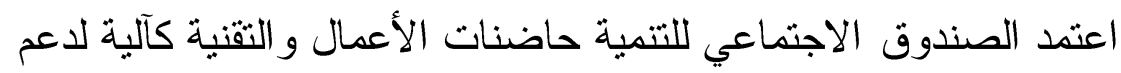
إقامة المشروعات الصغيرة وتتمية مهارات العمل لاى خريجي الجامعات، الاتهي، وجاءت فكرة إنشاء الجمعية المصرية لحاضنات المشروعات الصغيرة وهي وهي

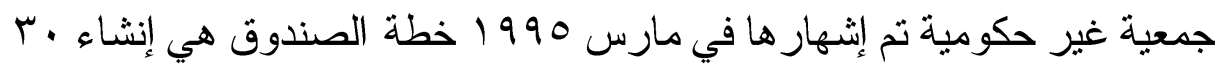
حاضنة في مصر، تم إنشاء 9 حاضنات حتى نهاية ب . . r و على سبيل المثنال هناك حاضنات تعنمد علي تكنولوجيا مبسطة في تقديم الخدمات أو التصنيع

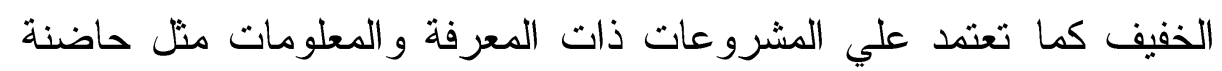
المنصورة وتلا وأسيوط، أي أنها حاضنة للصناعات العادية و الحرفية المميزة وذات الجودة العالية وهناك حاضنات التقنية وهي موجودة بالقرب أو داخل

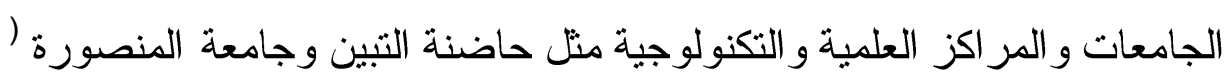

أهمية إنشاء الحاضنات التابعة الصندوق الاجتماعي للتنمية في مصر ( \&ه ) - ت توفير الدعم للمشروعات داخل وخارج الحاضنة. - تشجيع روح المبادرة ومساعدة المشروعات الصغيرة في مواجهة المعوقات التي قد تو اجههم في مرحلة البدء. - تمية المهار ات العملية و الإدارية للمبادرين. - مساندة المشروعات في بداية إنشاءها وحتى الوصول إلى مرحلة الاستقرار و الاعتماد على الذات.

- - مساعدة المبادرين في استخر اج التر اخيص اللازمة للبدء في النشاط.

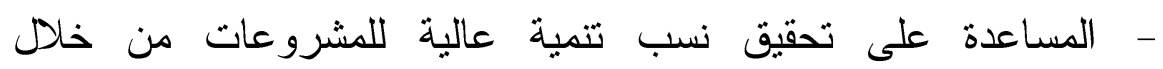
المساعدات و الخدمات المقدمة من الحاضنة. 
- خلق فرص عمل جديدة ( دائمة / غير دائمة ومباشرة / غير مباشرة

- خلق قنوات اتصال بين المشروعات الملتحقة بالحاضنة و المجتمعات

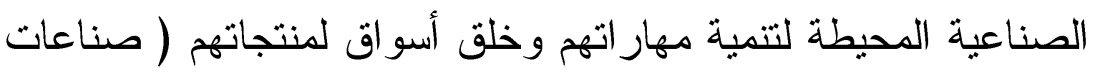

$$
\text { مغذية ). }
$$

- تطويع الأفكار القائمة على التكنولوجيا والأبحاث لتحويلها منتجات قابلة للتسويق.

- تقديم حزمة متكاملة من الخدمات مثل ( قياس الجودة ، المواصفات ،

$$
\text { قاعدة بيانات فنبة وتجارية ). }
$$

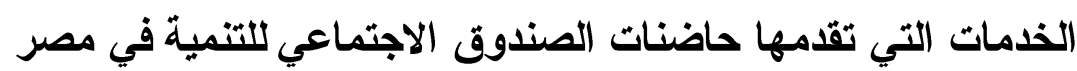
تقدم الحاضنة حزمة متكاملة من الخدمات التي ترتبط مباشرة

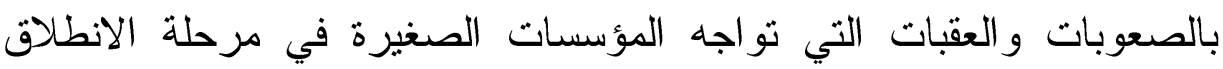
ويمكن للحاضنة أن توفر هذه الخدمات بنفسها أو بالاستعانة بجهات خارجية،

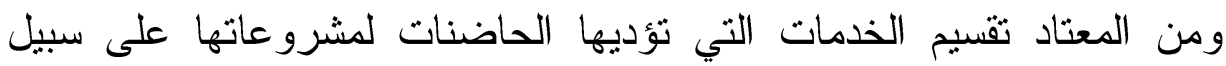

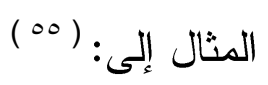

- خدمات إدارية : مثل خطة عمل، تدريب مهارات إدارية، أعمال سكرتارية، خدمات إنترنت، خدمات فاكس وكمبيوتر ... الخ.

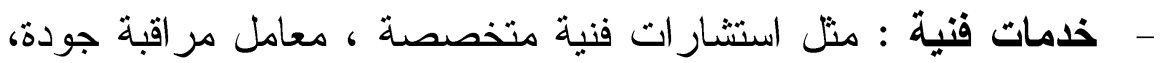
تدريبات فنية. - خدمات مالية : مثل تقديم قروض الصندوق الاجتماعي، دراسات الجدوى، مستتدات مالية. - خدمات تسويقية : مثل خدمات الدعاية و المشاركة في المعارض مله

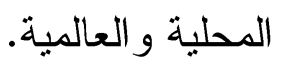


- المعامل : يتم در اسة إقامة معامل بكل حاضنة حيث يتم تحديد طبيعة

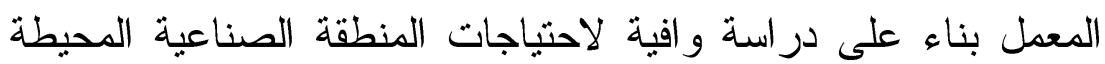

\section{بالحاضنة}

- القرض الاوار : وهو لية جديدة من آليات الصندوق داخل برنامج

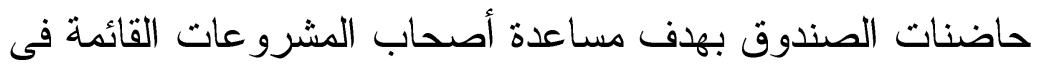
تمويل دورة رأس المال العامل لمشرو عاتهم وخاصة الذين لايهر بهاب

$$
\text { آلية الاتحاق بالحاضنة ( تهاقدات وأو امر توريد تحتاج تمويل فورى. }
$$

تعتبر الحاضنة منظومة صغيرة من الأنشطة تدار بواسطة هيكل إدارة

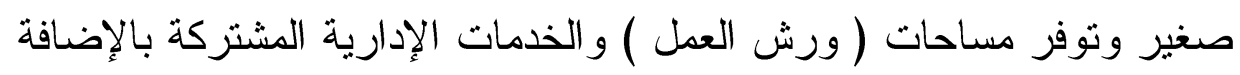
إلى خدمات الدعم الفني المشروعات و الدعم التمويلي والتسويقي نظير مقابل

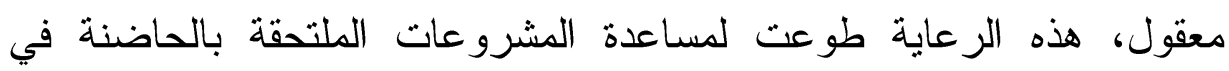

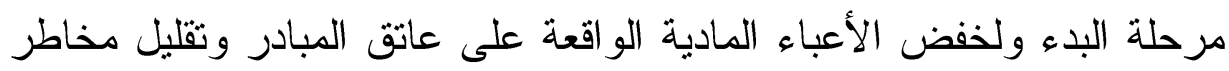
الفشل للمشروعات الصغيرة. مما يعنى إن الحاضنة تقوم بتقديم كافة أوجه الدهاء

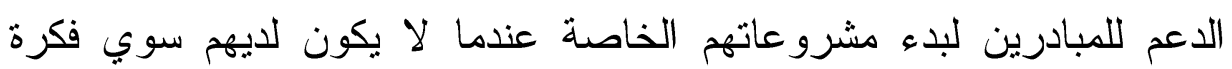

$$
\text { مشروع جيدة و إصر ار قوي. }
$$

يقوم مستقيدى الحاضنات بسداد مقابل نقدي ( إيجار / اشتر الك ) يتز ايد بشكل تدريجي بحيث يكون أقل من معدلات السوق في بداية النشاط. تقوم

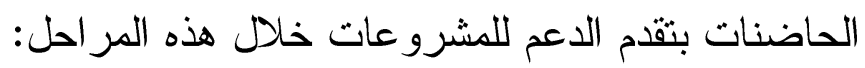

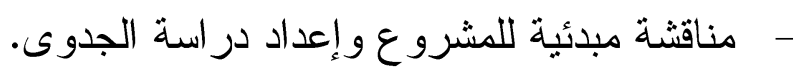
- - إعداد خطة المشروع. - - الانضمام للحاضنة و البدء في النشاط. - - التوسع حتى الاستقر ار -

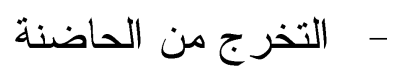




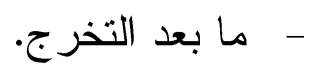

ب-تجربة الحاضنة التكنولوجية بالتبين التابعة لمعهد التبين للاراسات

\section{المعدنية}

\section{معهد التبين للار اسات المعدنية}

أنشئ معهد التبين للار اسات المعدنية ومارس نشاطه منذ عام 197 إست وقد

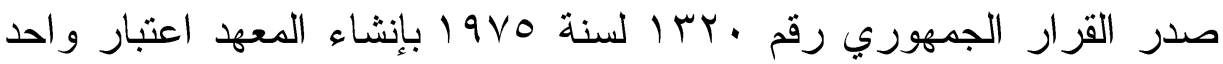
من المؤسسات العلمية في تطبيق القانون رقم 79 لسنة بr9 إحدد أهدافه فيما يلي : من اليؤيسات

1- إعداد المتخصصين من المهندسين وغيرهم من خريجي الجامعات و المعاهد العالية اللازمين في فروع الصناعات المعدنية والتعدينية وكيماويات الكوك و الحراريات وتخطيط هذه الصناعات و اقتصادياتها

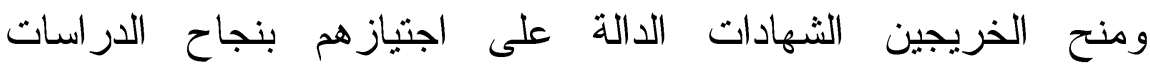
التخصصية التي قامو ا بها . أنمان ץ- المساهمة في أعمال التخطيط ورفع الكفاية الإنتاجية وتتظيم النشر العلمي وتتشيطه في مجال الصناعات المذكورة للمعهد في سبيل تحقيق ذلك : ( )

$$
\text { القيام بتوفير الدراسات العلمية و التكنولوجية. }
$$

القيام بالبحوث العلمية و التطبيقية و المعطلية المتعلقة بالمشاكل الصناعية المحلية في مجمع الحديد و الصلب و الثركات المشتخلة في مجالات الصناعات المعدنية للوصول إلى حلول أساسية لها في سبيل تطوير الطرق الصناعية. إيفاد بعوث علمية وعملية داخلية وخارجية.

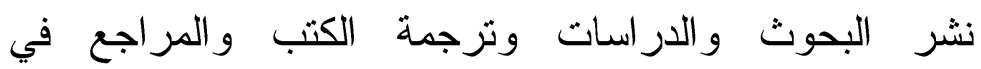
الصناعات المعدنية و التعدينية وتأليفها 
ويتفرد المعهد بإمكانياته في مجال رعاية الكوادر البحثية للصناعة

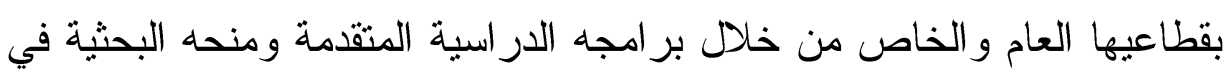
مصر و الدول العربية الثقيقة، كما بتفرد بإمكانياته في مجال نوفير المعلومات برات

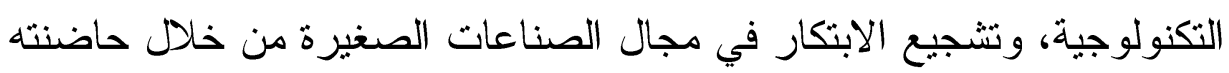

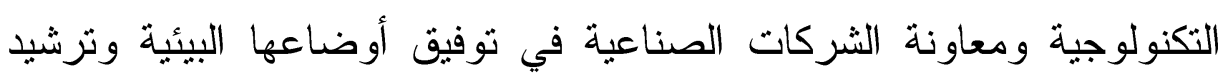

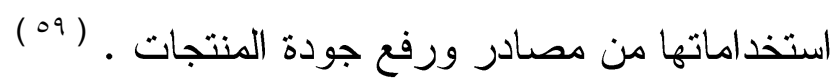
ويضم المعهز مر اكز أنشطة ووحدات ذات بودة طابع خاص متعددة تتمتع بنوع من الاستقلالية تتيح لها الانطلاق في تحقيق الأهداف الإستراتيجية للمعهد، كما تتيح لله إمكانبات تدبير موارد ذاتية لتخفيف الأعباء عن كاهل

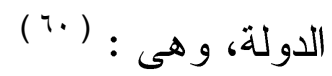

1- مركز در اسات التصنيع و التتمية التكنولوجية . Y- مركز تتمية الموارد البشرية و الصناعات الصغيرة . مرحسية

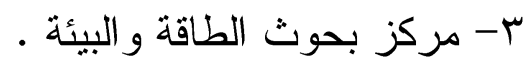

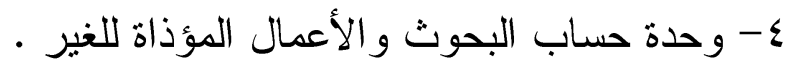
0- الحاضنة التكنولوجية. حاضنة التبين للمشروعات التكنولوجية

نبذة عن حاضنة التبين للمشروعات التكنولوجية ( ل) تم عمل عقد إنشاء حاضنة التبين بين معهد التبين وجمعية حاضنات الأعمال التابعة للصندوق الاجتماعي سنة 1991 ثم عدل هذا العقد ليكون بين

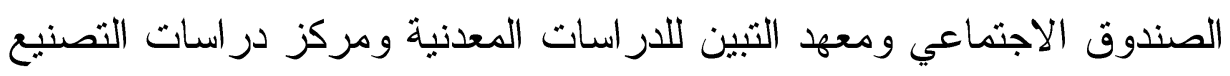
و التتمية التكنولوجية ونم استقبال الدورة الأولي للمشروعات الصنات الصغيرة ذات

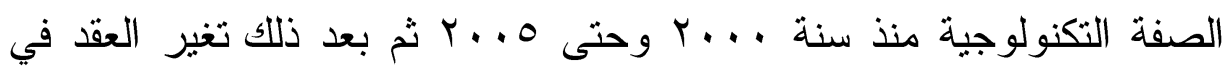

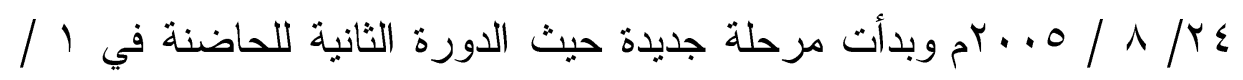

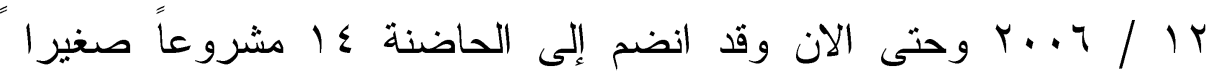


تكنولوجياً، وتعد حاضنة التبين جزء من منظومة تكنولوجية متكاملة تتضمن مؤسسة بحثية ونطبيقية منواجدة في المنطقة الصناعية بالتبين جنوب القاهرة هونة هونه

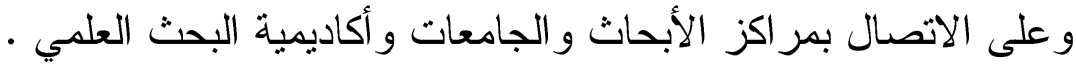

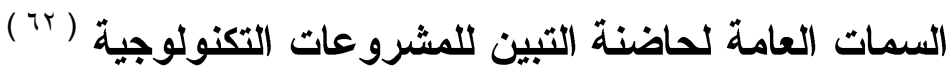

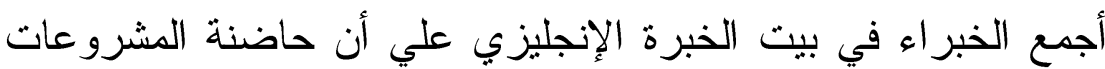

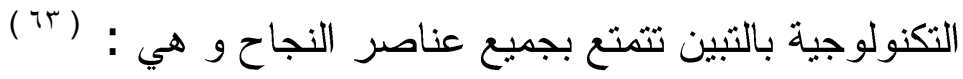

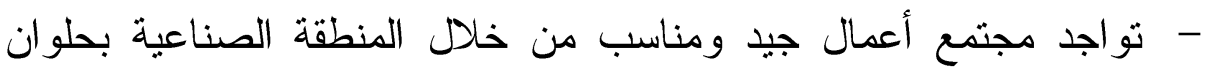
و التبين

- تواجد شبكة كبيرة من القدرات البشرية غير المستغلة وخاصة لدي الشركات بعد الخصخصة و إعادة الهيكلة لبعض الشركات.

الخدمات الأساسية التي تقدمها حاضنة التبين للمشروعات التكنولوجية

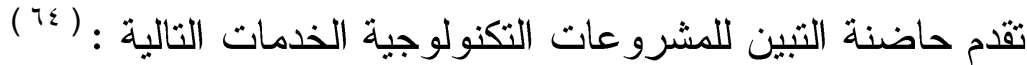
- الدعم الإداري و المالي و الدعم التسويقي داخل الحاضنة وعمل دراسات الجدوى المجانية وتوفير التنريب الفني علي الآلات للعاملين والتدريب المالي و التمويل و التدريب التسويقي و المزيج التسويقي ( الإنتاج و التسويق

$$
\text { و التسعير و الإعلان و التزويج و التوزيع ) • }
$$

- - دراسة العرض و الطلب وبحوث التسويق علي المنتج وكذلك التدريب لعمل خطة المشروع للبدء و التنفيذ و النجاح . - أنها تعد مركز تسويق، ومعرض، ومركز اتصالات، وصالة للتدريب، ومركز للإدارة، وقاعة اجتماعات .

شروط اختيار المشروعات في حاضنة التبين للمشروعات التكنولوجية

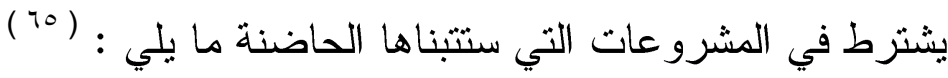
- - أفكار تكنولوجية واختر اعات ل 


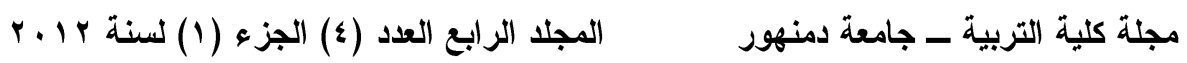

- مشروعات غير ملوثة للبيئة - مشئ

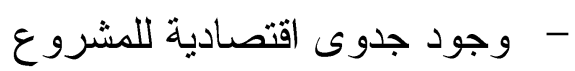
- - وجود منتج ذو جودة عالية

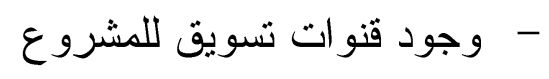

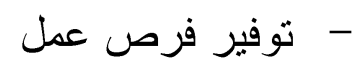

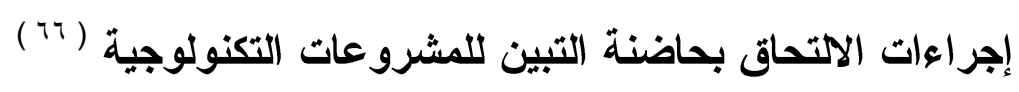

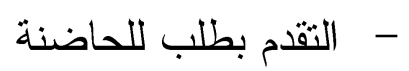
- - إجر اء مقابلة شخصية مع مدير الحاضنة

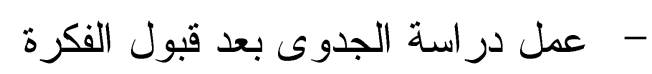

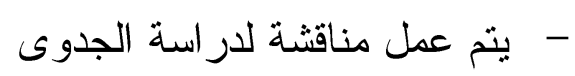

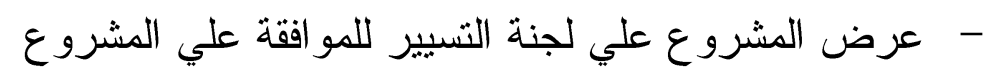

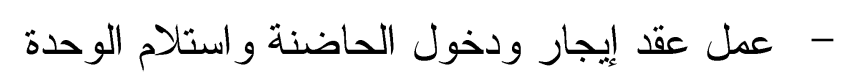

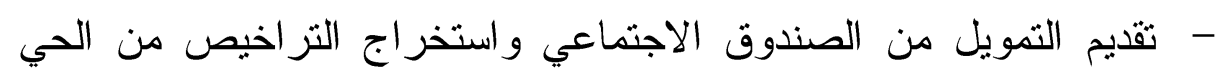
ووزارة الصناعة

- دخول الآلات و الخامات و العمالة وبدء الإنتاج و التسويق

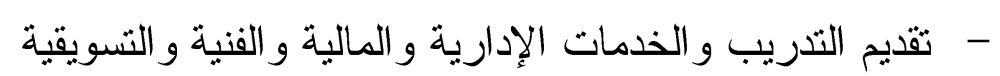
- تقديم الخدمات الإعلانية بوسائل الإعلان

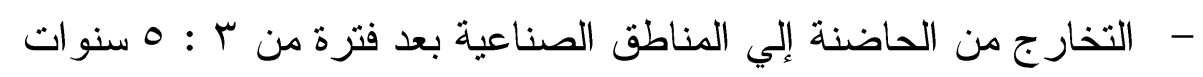
الاتتساب لحاضنة التبين للمشروعات التكنولوجية ( TV ) تعمل الحاضنة كمكتب استشاري لتقديم الخدمات المالية والإدارية و الفنية والتسويق ودراسات الجدوى والجودة الشاملة وذلك لإنجاح هذه

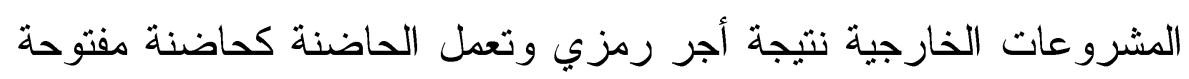

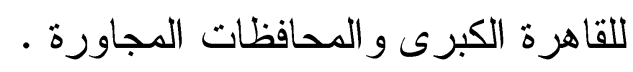


تجربة الأردن في مجال الحاضنات ( 7 )

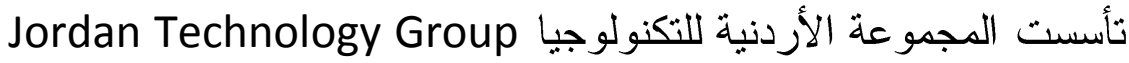
في عام 9191 1، وكان الهذف من هذه المجموعة هو :

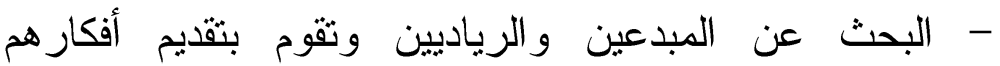

بالاعتمادعلى مواصفات ومعايير معينة بحيث نعتقد إدارة المجمو عة بأنها تشكل فرصة متاحة اقتصادياً مع إمكانية إدارة

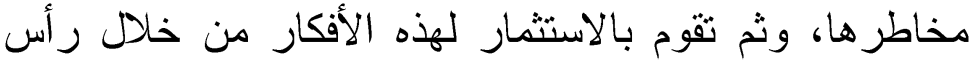

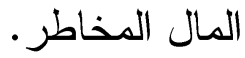

- مساعدة المبدعين من خلال توفير العديد من الخدمات مثل :

الإدارة المالية، التسويقية، الثؤون القانونية و السكرتارية ومساحة مكتبية وغيرها، وبهذا فإن المجموعة الأردنية للتكنولوجيا تستثر أموالها في مشاريع ريادية وهية بهدف خلق شركات تكنولوجية في المملكة الأردنية الهاشمية

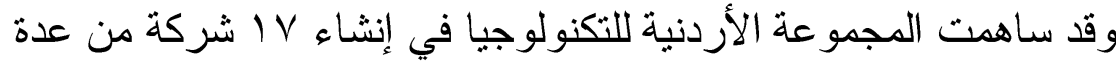
قطاعات مختلفة، وقد حقق قطاع تكنولوجيا المعلومات أعلى نسبة نجاح فيها. الخدمات المقدمة من المجموعة الأردنية للتكنولوجيا للمشروعات المتواجدة في حاضنة الأعمال

- - انتقاء أعضاء فريق العمل في المشروع - ت تحديد خطط العمل، و الأهداف و الأعمال المطلوبة - - متابعة أداء الثركة للمشروع الريادي

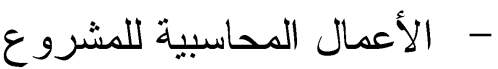
- - مياغة وتحديد التعليمات الإدارية - المساعدة في كتابة و إعداد النشر ات التسويقية و التعريفية 
- - تقديم الاسنشارات القانونية على الاتفاقيات وقوانين العمل و الضمان الاجتماعي و الضر ائب و الملكية الفكرية - - ملق وعي عام للمشروع الجديد - - تسويق المنتجات و الخدمات الجديدة

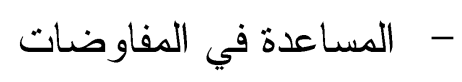
- - الاستشار ات المالية و الإدارية - تحديد الأنظمة المالية - مساندة الشركات في متابعة الأمور و الإجر اءات الرسمية لدى النى الجهات المعنية

$$
\text { - - توفير خدمات سكرتارية }
$$

- مضع معايير وتقييم كيفية التوظيف وشر اء الأجهزة و المعدات

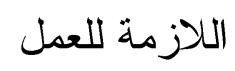

- - مساندة تطوير أعمال الثركات.

التصور المقترح لاور الحاضنات التكنولوجية كمدل لتطوير دور الجامعة في لئل

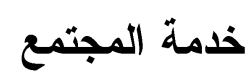

تعد الحاضنات التكنولوجية المكان الذي يقوم بتقديم خدمات وخبرات

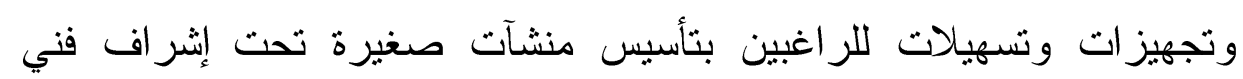
و إداري من قبل أصحاب خبرة واختصاص بالجامعات، و إلى " تبني" المبدعين

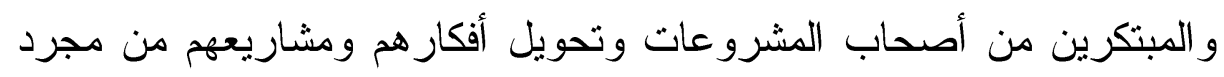
فكرة إلى الإنتاج والاستثمار، من خلال توفير الخدمات التي تقدم للمبتكرين في وني

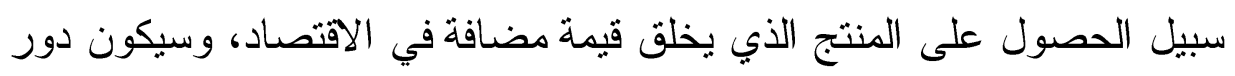

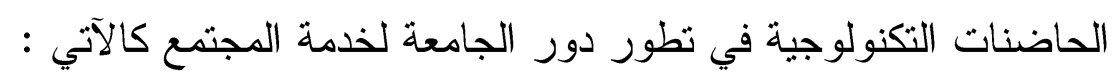


ا - تنمية القدرة على إدارة المشروعات ومهارات العمل الحر على عن طريق جعل الحاضنات التكنولوجية نواة أعمال لمشروعات الثباب لاعم المجتمع المحلي الموجود به تلكك الحاضنة r- دعم التنمية الاقتصادية من خلال : - - التطبيق الفعلي من خلال ممارسة العمل بجدية وحماس. - اكتساب القدرات و المهار ات و السلوكيات التي يتطلبها سوق العمل. - تحقيق أعلى معدلات نمو للمشروعات المشتركة بالحاضنة .

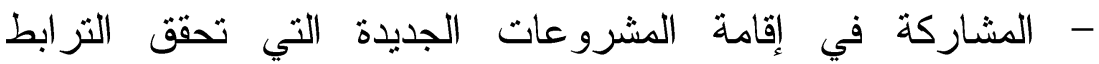
و التكامل مع المشروعات القائمة. - المشاركة في إقامة المشروعات التي تساعد في التحول من المشروعات الحرفية إلى الصناعات الصغيرة المنطورة . r- دعم المشروعات القائمة من خلال : - - تقديم خدمات للمشرو عات الصغيرة المحيطة - ربط الحاضنات بالمنشآت الصغيرة للعمل على تتميتها بصفتها بائعاً للمنتجات و الخدمات التي تسوقها - تبني المشروعات القائمة على التكنولوجيا و المرتبطة بالجامعات ومر اكز البحوث

- التركيز على التعاون الدولي و المادي و التكنولوجي لتسهيل دخول الشركات الصغيرة والمصريين العائدين من الخارج للاستثمار

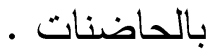

- تغذية المشروعات الصغيرة الوليدة في موقعها حتى لو انتقلت

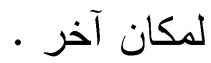
- مساعدة الشباب من خريجي الجامعات و المعاهد العليا على إقامة

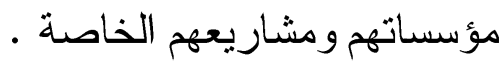


- تطوير أفكار جديدة لخلق و إيجاد مشروعات إبداعية جديدة أو المساعدة في توسعة مشرو عات قائمة .

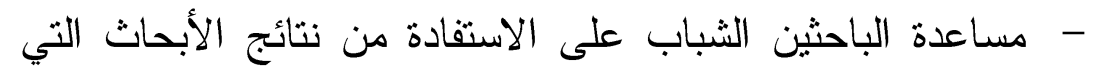

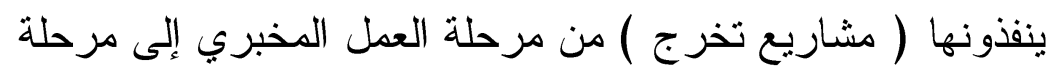

$$
\text { التطبيق العملي بهدف الإنتاج التجاري }
$$

- توفير الدعم و التمويل والخدمات الإرشادية والنسهيلات المتاحة لمنتسبيها نوفيز

$$
\text { - تقليص الخطر و أسباب الفشل للمشرو عات . }
$$

- تغيير ثقافة تقاسم الأخطار و العمل الجماعي و العمل في شكل شبكات

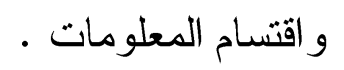

- مساعدة رواد الأعمال على إنشاء الثركات الصغيرة و المتوسطة

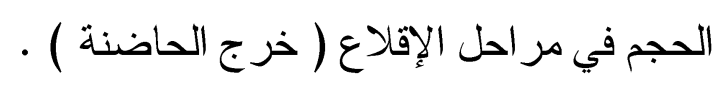

- ربط المؤسسات المختصة بالقطاعات الصناعية و التجارية محليًا

$$
\text { وربما في الدول الصناعية المتقدمة . }
$$

- المساهمة في توطين التكنولوجيا المستوردة و المساعدة في نقل فئل التكنولوجيا من الدول المتطورة تكنولوجيا وتعزيز استخداماتها و تطبيقاتها في المجتمع المحلي بما يخدم عملية البناء الاقتصادي .

\section{ع - تقديم الدعم للمشروعات الجديدة من خلال :}

- - مساهمة الحاضنات في تأسيس إدارة المشاريع الصغيرة. - قبام الحاضنات بالتعريف بالتطور ات المستجدة ورفع أساليب كفاءة إنة العمل.

- - بث روح المغامرة باقتحام سوق العمل.

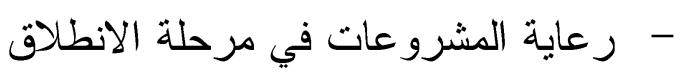
- - توفير الدعم المالي و الإداري والتسويقي هروي 
- - تقديم خدمات للمشروعات بداخل وخارج الحاضنة - التغلب على المشكلات التي تو اجه تتفيذ المشروع

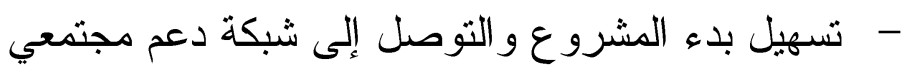
مكان إنشاء الحاضنات التكنولوجية

يفضل أن تكون الحاضنات التكنولوجية داخل الجامعات أو بجوارها وذلك للاستفادة من الإمكانات البحثية و المعامل وخبرات الأساتذة في كافة التخصصات التي سوف تغطي مجال عمل الحاضنات أسلوب العمل المقترح بالحاضنات التكنولوجية سوف تقدم الحاضنة المساعدة للمستقيد خلال المر احل المختلفة من عمر

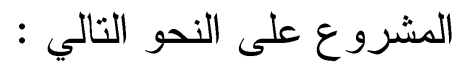
1-مرحلة الاراسة الأولية والتخطيط .. من أجل للتأكد من جدية صاحب الفكرة أو المشروع، ومدى انطباق معايير الاختبار على المستفيدين و على مشاريعهم. ץ-مرحلة إعداد خطة المشروع .. في ضوء ضعثة نتائج المرحلة الأولى سوف

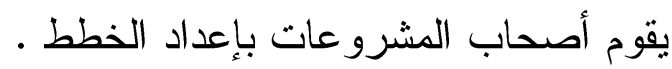

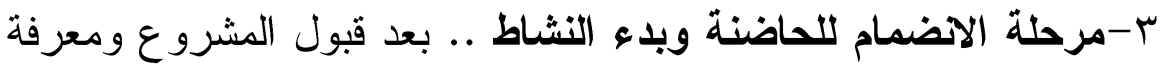
جدواه سوف يتم التعاقد مع صاحب المشروع، ويُخصص له مكان مناسب في الحاضنة وفق هذه الخطة. ع-مرحلة التوسع والتظوير ... يتم متابعة أداء المشروع وتوفيه المساعدات و الاستشار ات لتحقيق معدلات نمو عالية. 0-مرحلة التخرج من الحاضنة .. حيث يكون المشروع قد أصبح قادراً على تأدية وتظوير نشاطه خارج الحاضنة، ويصبح صاحب المشروع

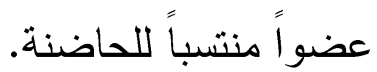




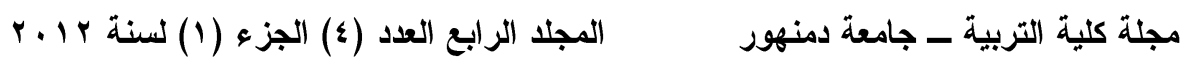

؟-مرحلة المتابعة بعد التخرج من الحاضنة، أي متابعة معدل أداء المشروع وتذليل العقبات التي يواجهها في بداية مرحلته الانتقالية

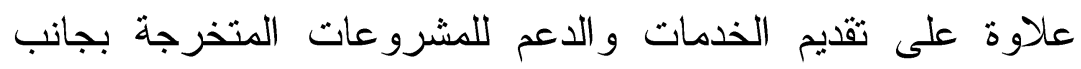
مشاركته في الندوات وورش العمل والدورات التدريبية و الاشتر الك في المعارض التي تقيمها الحاضنة بالتعاون مع الجهات المحلية المعنية. الفئات المستفيدة من الحاضنات

- - من لديهم أفكار مشاريع تكنولوجيا المعلومات و الاتصالات (ICT) - - مريجو الجامعات ذات التخصصات المناسبة. - أعضاء هيئة التذريس بالجامعات.

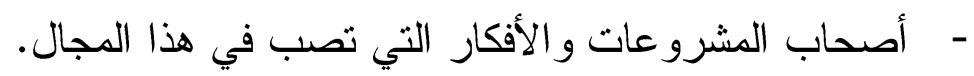

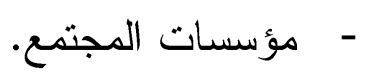
ويشترط لقبول الأفكار والمشروعات في هذه الحاضنات ما يلي:

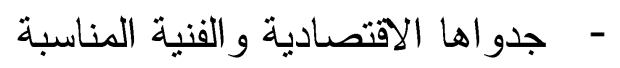
- - أن يكون ملبياً لحاجة المجتمع من حيث الجودة و السعر المناسب. - أن يوفر فرص عمل للر اغبين في عمل. - أن تكون له صفة الاستدامة في سوق العمل . - مدى مساهمته في زيادة الدخل القومي الإجمالي.

العائد المتوقع من إنشاء الحاضنات التكنولوجية لتطوير دور لادئ الجامعة في لئي

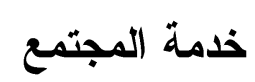
ا-على الطلاب وأصحاب الأعمال - - منح ومزيد من فرص النجاح، تعزيز التقة، تحسين المهارات وخلق ربط مع مختلف القطاعات، تسهيل عملية الاتصالات وتوفير تعرير المعلومات و المعدات البسيطة و المكان للعمل. 
- تعميم الأفكار عن طريق نشر الأفكار الجديدة باستمرار لتمكين الثباب من تقديم أعمال منميزة.

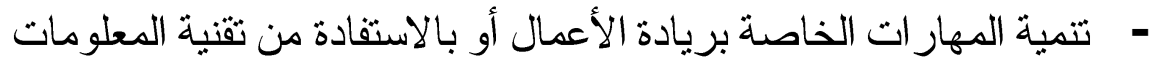

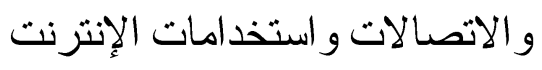

- إكساب المهارات عن طريق بناء القدرات والمهارات و التطوير و الإرشاد للمحتضنين التي تكفل إطلاق ملكاتهم وإبداعاتهم وتحسين فرصهم في العمل المتبع. - زيادة الكفاءات من خلال ضمان وجود كفاءات متميزة واستقطاب كفاءات جديدة لسوق العمل r - بلى الاولة

المساهمة فى النمو الاقتصادي للاولة وتعزيز برامج التتمية المستدامة، و المساعدة في تجنب فثل الأسواق وكسادها كما تروج للنطوير و التتمية الإقليمية، وتخلق فرص عمل، وجود الحاضنة يكون بمثابة إعلان التزام الدولة

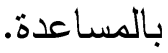

\section{r-على الجامعات ومر اكز الأبحاث العلمية}

- الحاضنات تساهم في زيادة التواصل بين الجامعات ومر اكز التدريب ومراكز البحث العلمي ومختلف الأنشطة الاقتصادية وتساعد في رهي تسويق الاختراعات للمستثرين، وتخلق الفرص لطلاب الدراسات العليا والباحثين للاستخدام الأمثل لكفاءتهم وقدراتهم وتشجيع ابتكار اتهم. - تطوير الأساليب المستخدمة في قطاع المعلوماتية والاتصالات لاستحداث أنشطة جديدة تقدم قيمة مضافة. - - نشر الثقافة المعلوماتية وصو لاً إلى أداء متميز وخدمات أفضل. - رعاية البحوث العلمية المبتكرة وطريقة تطبيقها في الو اقع. 
- إثر اء المعرفة النظرية التي تدرس لطلاب الجامعات.

\section{ع - على قطاع الإنتاج والخدمات والمؤسسات الصغيرة و المتوسطة}

- تطور فرص زيادة الاختراعات وتخلق الإدارة المتسلسلة وفقاً

للمسؤوليات الاجتماعية وتتمى اقتصاد المعرفة و الملكية الفكرية. - توفير المرافق الأساسية من مختبر ات ومعامل وتجهيز ات و الاحتياجات لإضافية من أجهزة وبرامج وخدمات تثنية المعلومات وشبكات الاتصالات، وتوفير متطلبات البنية التحتية للمنشآت المنتسبة لها عن طريق المشاركة أو التسيق مع الجامعات ومر اكز الأبحاث و هيئات نقل التكنولوجيا أو عن طريق الاستئجار، ويتم توفير متطلبات البنية التحتية للمنشآت المنتسبة لحاضنات ثقنية موجودة في المناطق التقنية من قبل هذه المناطق نفسها أو بالتسيق مع الجامعات ومر اكز الأبحاث ومقدمي الخدمات المساندة المرتبطين بها، أما بالنسبة للحاضنات المرتبطة بالجامعات ومر اكز الأبحاث؛ تعتبر استفادة المنشآت المنتسبة لهذه الحاضنات من الأكاديميين و الباحثين و الطلاب في هذه الجامعات و مر اكز الأبحاث عن طريق تقديم الاستشار ات أو بالمشاركة في الأبحاث و التسويق - توفير الخدمات القانونية المختلفة التي تحتاج إليها المنشآت المنتسبة لها (سو اء ما يتعلق منها بتأسيسها وتسجيلها وكتابة عقود التر اخيص أو ما يتعلق منها بحماية الملكية الفكرية وبراءات الاختر اعات )، ويمكن للحاضنات تخفيض التكلفة العالية المرتبطة بتوفير الخدمات القانونية إلى المنشآت المنتسبة لها وذلك بتوحيد مقدمي هذه الخدمات و الاتفاق معهم لتقديمها بصفة دائمة وجماعية، ومن المؤكد أن حماية حقوق الملكية الفكرية وبر اءات الاختر اع عملية جو هرية في مساعدة المنشآت المنتسبة لحاضنات الأعمال التقنية في تطوير الأسو اق لمنتجاتها. 
- يمكن للمنشآت المنتسبة للحاضنات التقنية المرتبطة بالجامعات تخفيض التمويل اللازم لها بموجب ترنيبات تشارك فيها هذه الجامعات في ملكية لهية هذه المنشآت مقابل حقوق الملكية والاستفادة من بر اءات الاختر اعات

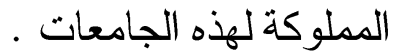

- قتوم حاضنات الأعمال ببناء شبكات التو اصل عن طريق الدعوة لندو ات ومعارض تستهدف استقطاب الجهات المحتمل استثمار ها في المنشآت المنتسبة لهذه الحاضنات، كما تقوم الحاضنات ببناء شبكات التو اصل فيما بينها للمشاركة في الخبر ات وتجنب الازدو اجية، مع استمر ار الحاضنات في التو اصل مع المنشآت المتخرجة منها عن طريق تقديم بعض الخدمات التي كانت تقدمها لها قبل تخرجها تسهيل وصول المنشآت المنتسبة للحاضنات إلى مصادر التمويل المختلفة

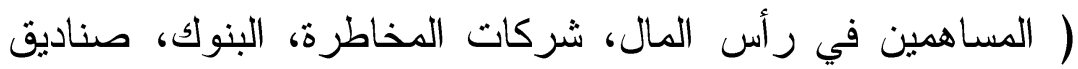

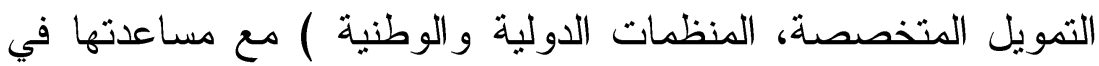
إعداد خطط العمل اللازمة للاتصال بالراغبين في الاستثمار في هذه المنشآت - يمكن للحاضنات نفسها المشاركة في ملكية هذه المنشآت موفرة بذلك

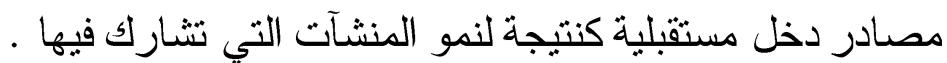

\section{المجتمع المحلي و الاولي}

- -

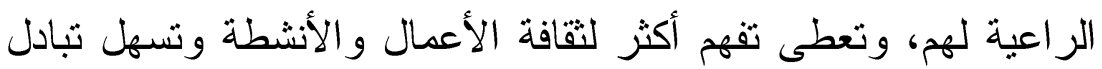
الخبرات سواء بالمشاركة أو الاتحاد أو التبادل.

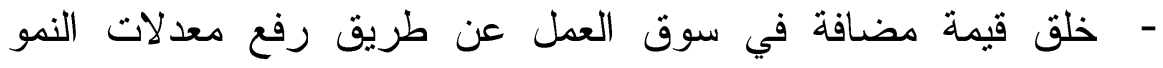
الاقتصادي من خلال تأسيس شركات حديثة بأساليب تكنولوجية حديثة، وتوفير فرص عمل، وتوفير مشاريع ذات جودة عالية وأسعار منافسة. 


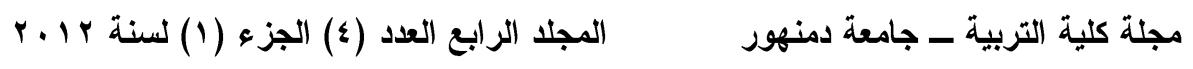

معايير نجاح الحاضنات التكنولوجية في تطوير دور الجامعة لخدمة المجتمع :

يقاس مدى نجاح الحاضنات التكنولوجية في دعم المؤسسات الصغيرة

و المتوسطة وفق مجموعة معايير منها :

- - مدد المشروعات المتخرجة من الحاضنة.

- - نسبة المشرو عات الناجحة بعد التخرج من الحاضنة.

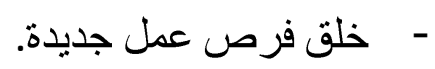

- - عدد المنتجات و الخدمات الجديدة التي تمت تتميتها في الحاضنة.

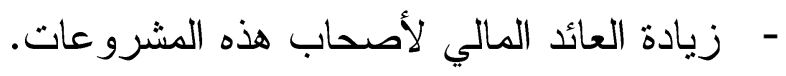

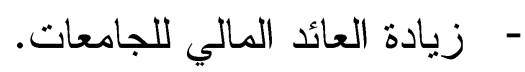

- زيادة مساهمة هذه المشروعات في الناتج القومي الجمالي للدولة.

الصعوبات التي يمكن تواجه مشروع الحاضنات التكنولوجية

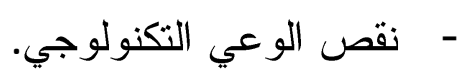

- التخوف تقبل الحاضنات التكنولوجية ودورها في دعم المجتمع وعم

الاقتصاد.

- - - تز اجع تقديم الدعم المالي.

المقترحات لمعالجة هذه الأخطار

- القيام بحملات التوعية في وسائل الإعلامهو التوسع في عقد محاضرات

وندوات وورش عمل للتعريف بأهداف الحاضنة وأنشطتها .

- تتسيق العلاقات مع المنظمات المحلية و الإقليمية والدولية والجهات

الداعمة و الهيئات الممولة لمشرو عات الحاضنات. لهين. 


\section{المراجع}

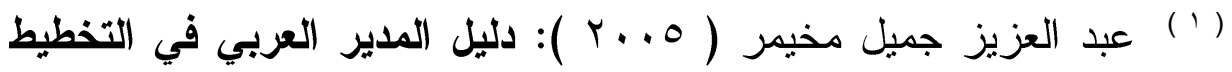
الاستراتيجي، المنظمة العربية للتنمية الإدارية التابعة لجامعة الدول

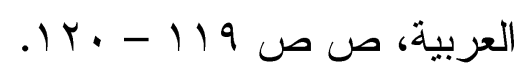

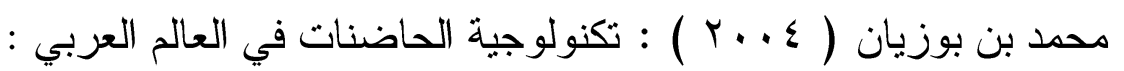

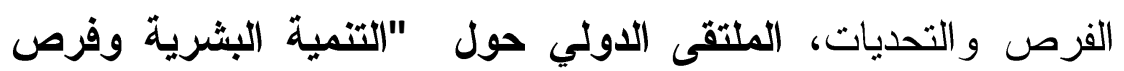

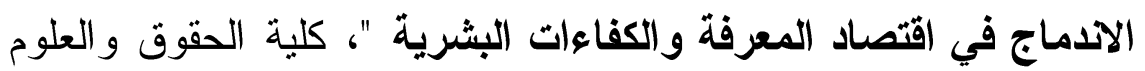

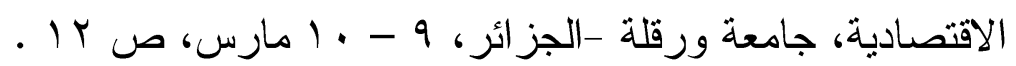

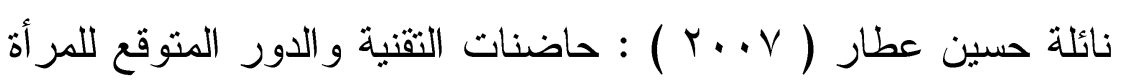
السعودية، الندوة التعريفية بحاضنات التقنية، مركز بحوث أقسام العلوم

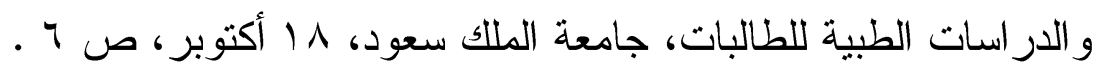
علي سماي ( · · r ) : دور الحاضنات التكنولوجية في دعم المؤسسات الصغيرة و المتوسطة، مجلة أبحاث اقتصادية وإدارية تصدر عن جامعة

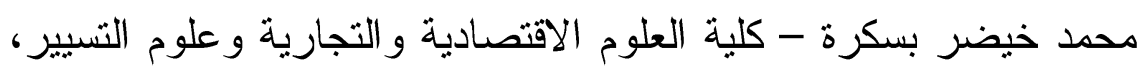

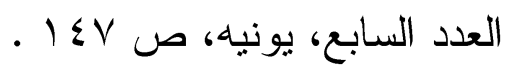

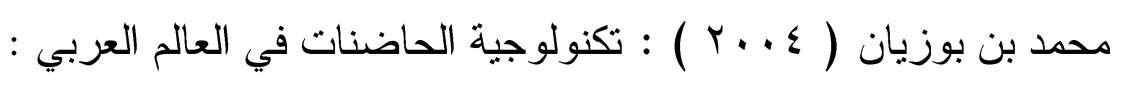

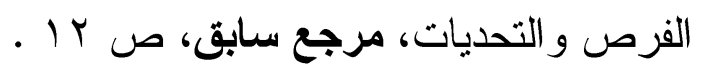

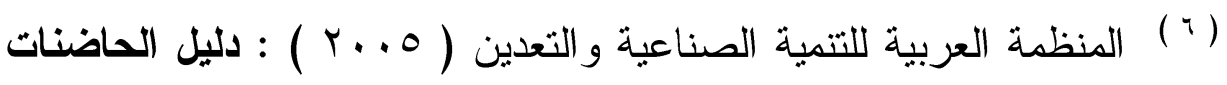
الصناعية، المنظمة العربية للتنمية الصناعية والتعدين، جامعة الدول

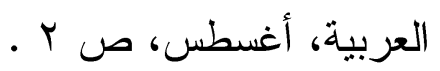


معهد البحوث والاستشار ات ( بr (1 هـ ) : حاضنات الأعمال، سلسلة

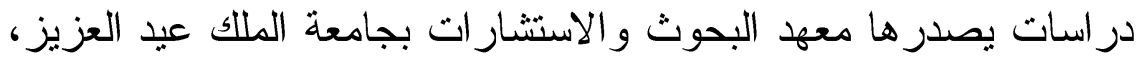

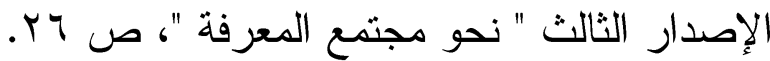

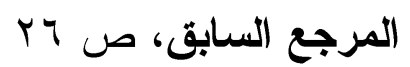

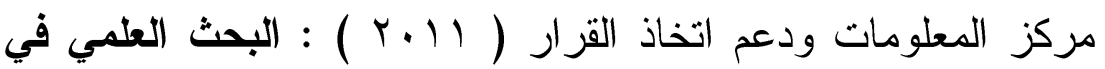

مصر ... هل يكفل التقدم المنشود؟، تقرير شهري يصدر عن مركز

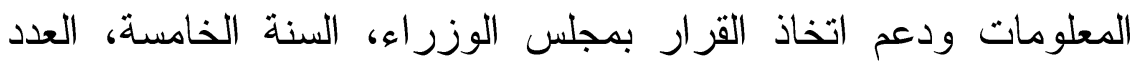

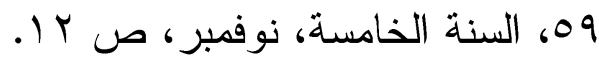

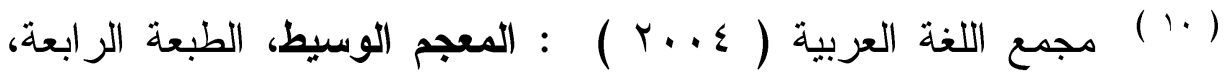
الإدارة العامة للمعجمات و إحياء التراث، القاهرة : مكتبة الشروق الدولية، ص . D

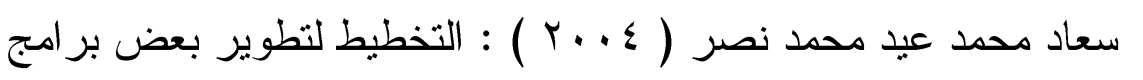
الدراسات العليا بكليات التربية، رسالة ماجستير غير منشورة، كلية

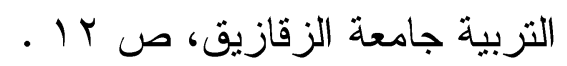

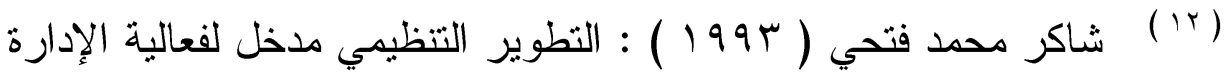

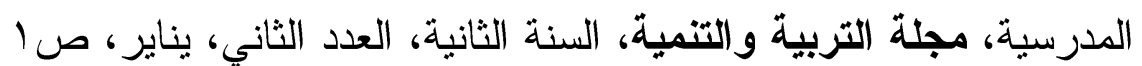

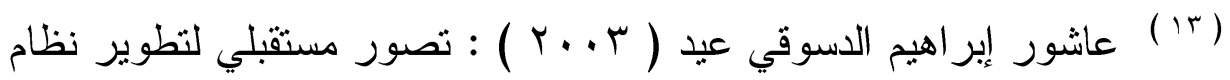
التعليم الثانوي العام في ضوء منطلبات التتمية البشرية، رسالة ماجستير

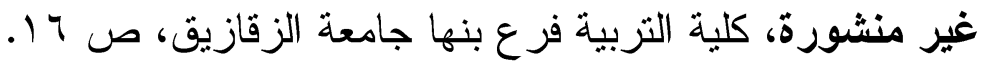

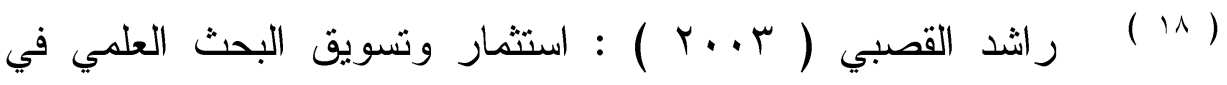

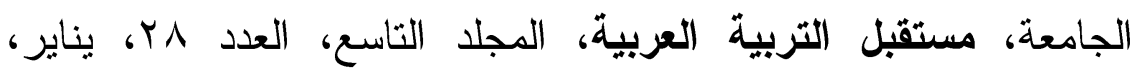

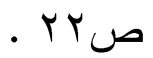


فرج مصطفى محمد الثافعي ( r . r ) ) : استر اتيجية مقترحة لتطوير

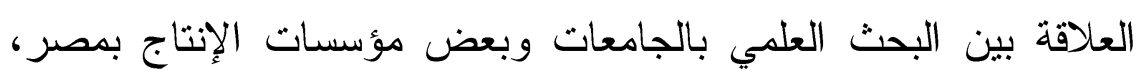

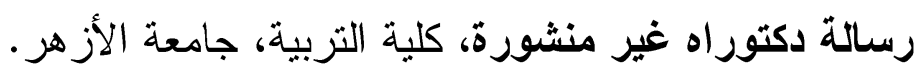

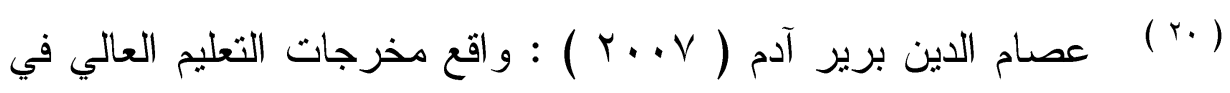

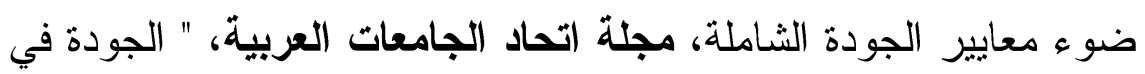

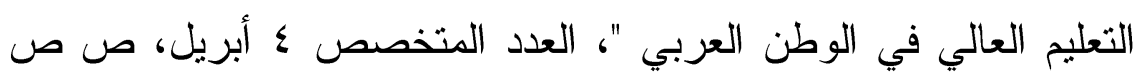
. $\leqslant \varepsilon)-~ r q 9 ~$

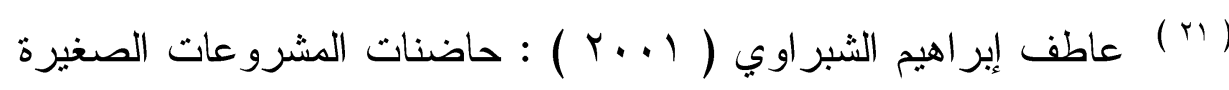

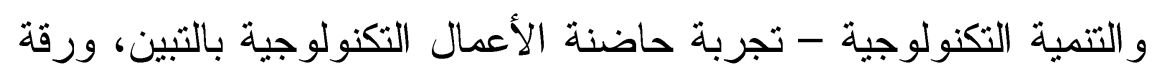

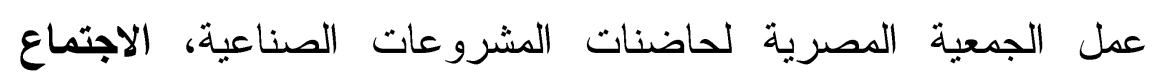
الثالث للجنة التنسيق لمراكز البحوث الصناعية في الدول العربية،

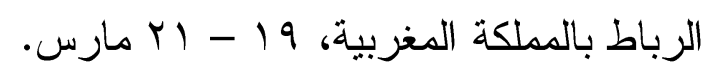

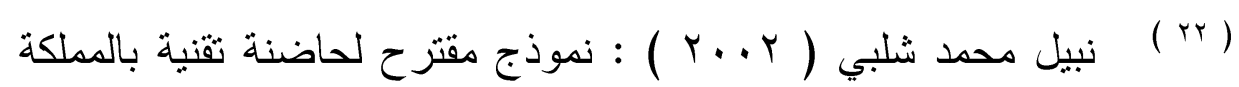
العربية السعودية، ورقة عمل مقدمة إلى ندوة " واقع ومشكلات المنشآت الصغيرة والمتوسطة وسبل دعمها وتنميتها "، مركز تتمية المنشآت

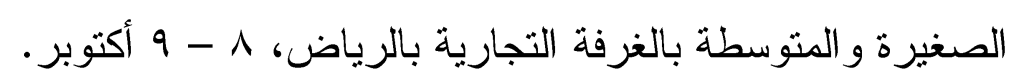

(rr) Peters, Lois and Rice, Mark and Sundararajan, Malavika ( 2004 ) : The Role of Incubators in the Entrepreneurial Process, The

Journal of Technology Transfer, Volume 29, Number 1, January,

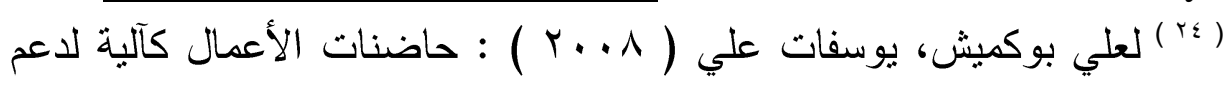
وتطوير البحث العلمي العربي، مؤتمر التعليم العالي في الوطن العربي

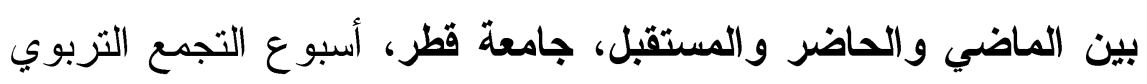

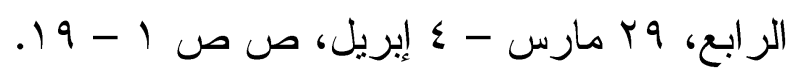




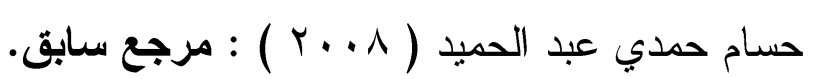

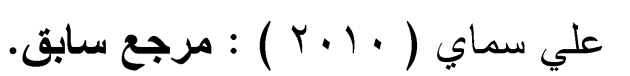

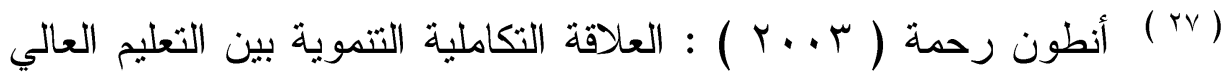
وقطاعات المجتمع وسبل تفعيلها، ندوة التعليم العالي روئة شاملة ودورة

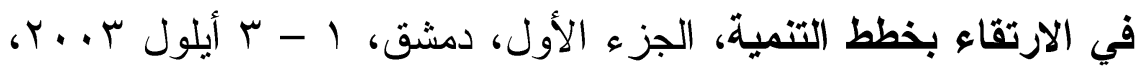

$$
\text { ص ص ص }
$$

يوسف سيد محمود ( ع . . F ) : التحالف و الثراكات بين الجامعات

و المؤسسات الإنتاجية ددخل لنطوير التعليم الجامعي، مجلة دراسات في التعليم الجامعي، مركز تطوير التعليم الجامعي، جامعة عين شمس، العدد

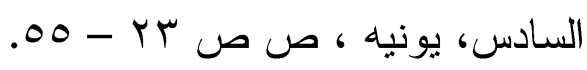

نبيل علي ( 1999 ) : العرب وعصر المعلومات، سلسلة عالم

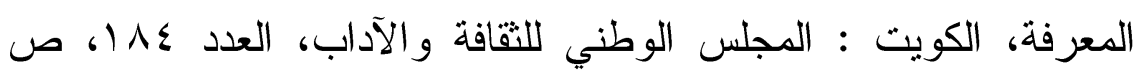

$$
\text { . rN }
$$

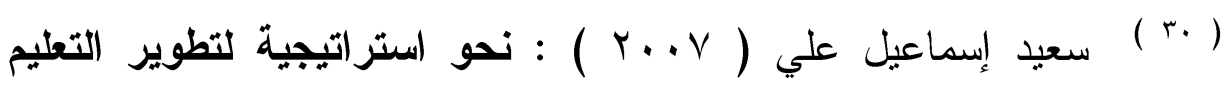

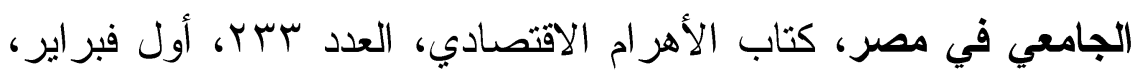

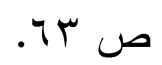

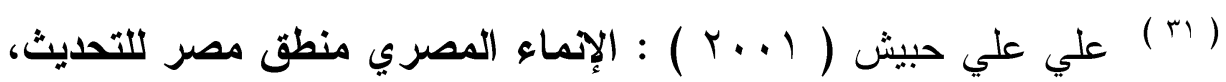

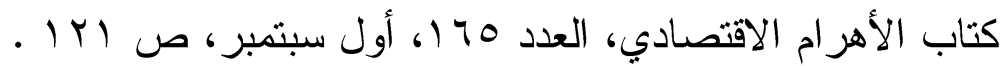

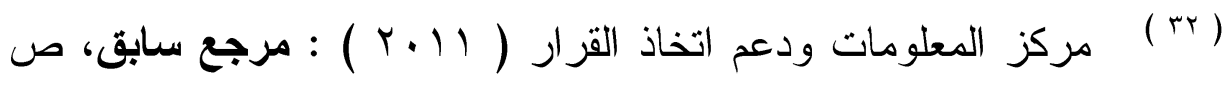

$$
\text { r }
$$

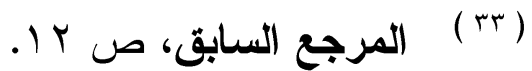

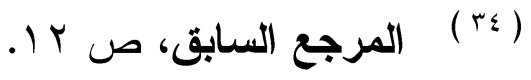


(ro ) منظمة العمل العربية ( ؟ . . F ) : مؤتمر العمل العربي، البند الثامن : الارتقاء بالقدرة الإنتاجية للقوى العاملة، الرباط، الدورة الثالثة والثالثون،

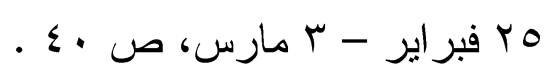

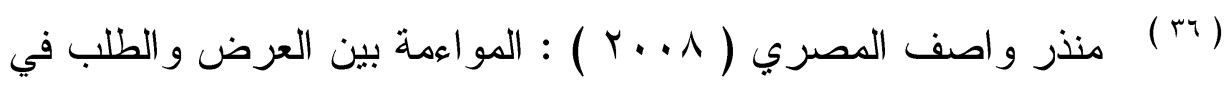
الموارد البشرية، ورقة عمل مقدمة من منظمة العمل العربية، المنتدى العربي للتنمية والتشغيل، الدوحة، 0 1- 17 نوفمبر / تشرين الثاني مئه . V ص

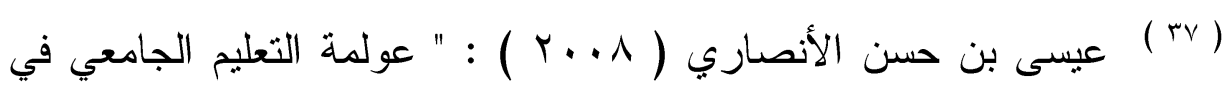
البلدان العربية "، مجلة الثقافة والتنمية، العدد جب، السنة الثامنة، يوليو،

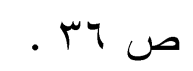

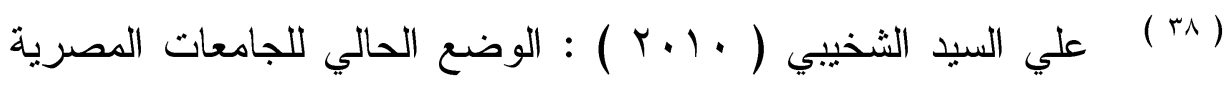
و امكانية تطويرها، الندوة العلمية السابعة بقسم أصول التربية بكلية التربية جامعة طنطا ( التخطيط الاستراتيجي في التعليم العالي )، 11

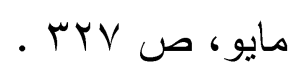

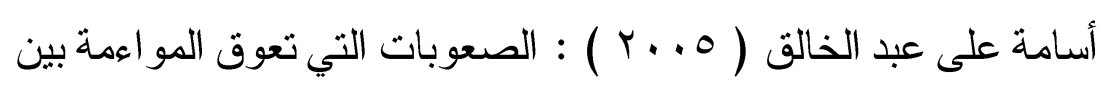
سباسات التعليم و التدريب المهني و التشغيل، ورقة عمل مقدمة إلى الندوة القومية حول متطلبات أسواق العمل العربية في ضوء المتغير ات الاولية،

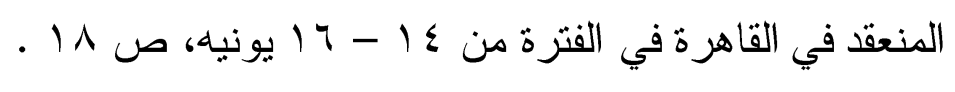
(10) العين وجدان التلهوني الساكت ( 0. . ب ) : حاضنات الأعمال تجربة ملتقى سيدات الأعمال و المهن الأردني، ورقة مقدمة في منتدى المرأة العربية والعلوم والتكنولوجيا، 1- . 1 كانون الثاني، القاهرة، ص . . . 


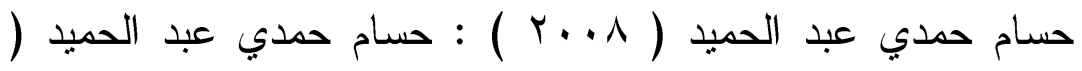

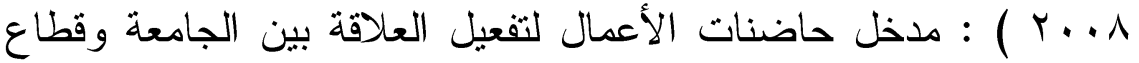

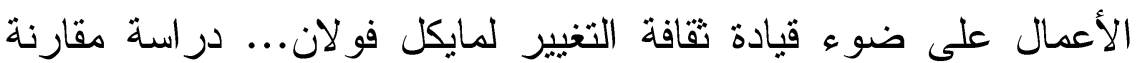

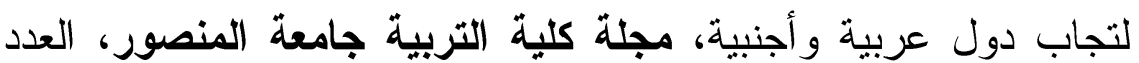

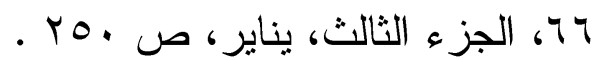

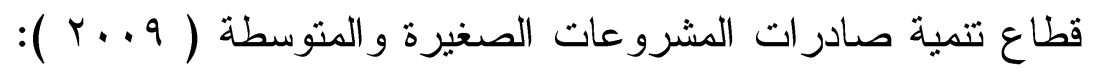

النشرة الاقتصادية الشهرية " ملتقى المشروعات الصغيرة والمتوسطة "

، قطاع تتمية صادر ات المشروعات الصغيرة و المتوسطة، وزارة التجارة

و الصناعة ، ج · م · ع ، العدد الثامن والاربعون، أغسطس، ص سبرع.

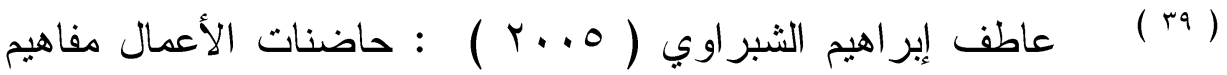

مبئية وتجارب عالمية، مرجع سابق.

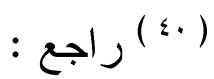

عبد الرزاق خليل، نور الدين هناء ( ؟ . . r ) ) دور حاضنات الأعمال في دعم الإبداع لاى المؤسسات الصغيرة في الاول العربية، مخبر العولمة

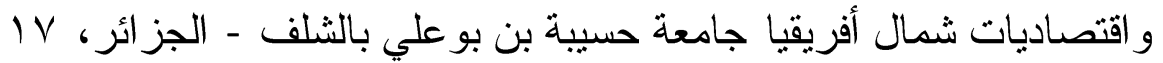

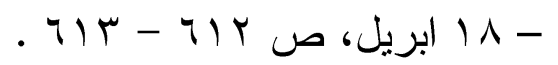

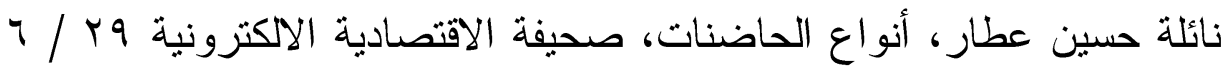
Available at

$$
\text { r... } 1
$$

http://www.aleqt.com/2006/06/29/article_5668.htm

Akçomak ,í. Semih ( 2009$)$ : Incubators as Tools for Entrepreneurship Promotion in Developing Countries, United Nations University (UNU) and The World Institute for Development Economics Research (WIDER), November, Research Paper No. 2009/52, PP 2 - 3

Daskalopoulou, Irene \& Liargovas, Panagiotis \& Petrou, Anastasia ( 2009 ) : A comparative study of business incubators and 
technoparks in the EU, Working Paper, October, Department of Economics, University of Peloponnese, Tripolis, Greece,PP 6

- 7, Available at http://econpapers.repec.org/paper/uopwpaper/

$$
\text { : راجع (s) }
$$

- الصندوق الاجتماعي للتنمية، جمهورية مصر العربية، حاضنات Available at الأعمال $\quad$ a $\quad$ التكنولوجية

.http://www.sfdegypt.org/web/sfd/embracing-businesses

$$
\begin{aligned}
& \text { - قطاع تتمية صادر ات المشروعات الصغيرة و المتوسطة ( } 9 \text { ( . r ) : } \\
& \text { مرجع سابق، ص سז } \\
& \text { : راجع }
\end{aligned}
$$

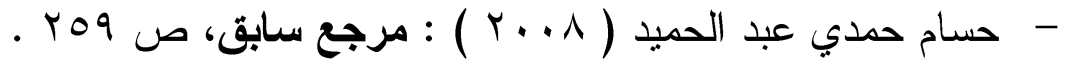

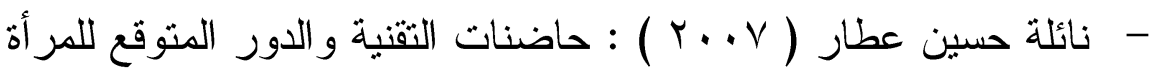

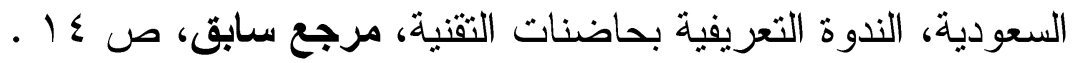

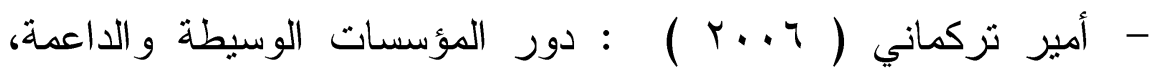
الجمعية العلمية السورية للمعلوماتية، " المؤتمر الوطني للبحث العلمي

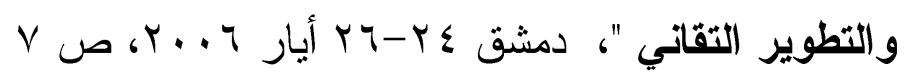

Available at http://tims- معهد التبين للهندسة و التعدين -

$$
\text { eg.com/DefaultAr.aspx?ID=17 }
$$

- Miyake, T. ( 2002 ) : UNIDO Technology Foresight Programme \& Business Incubation

$$
\begin{aligned}
& \text { - - الاجتماع الخامس للمنظومة العربية لتبادل المعلومات التكنولوجية، } \\
& \text { الرباط ، س ו-10 1 مارس }
\end{aligned}
$$

- Lalkaka, Rustam ( 2001 ) : Best Practices in Business Incubation: Lessons, yet to be Learned , ( International Conference on Business Centers: Actors for Economic \& Social Development, Brussels ), 14 - 15 November.

Available at: 
http://www.bii.ge/?action=page\&p_id=41\&lang=eng\#,., P 6

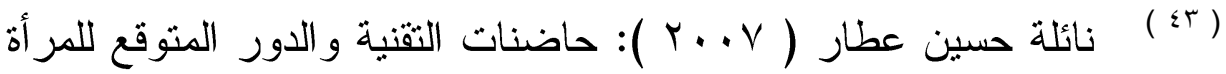

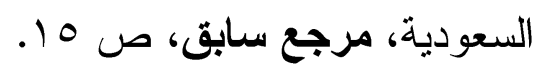

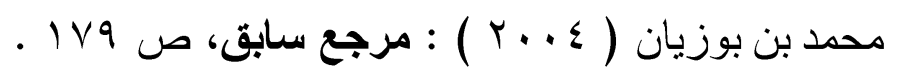

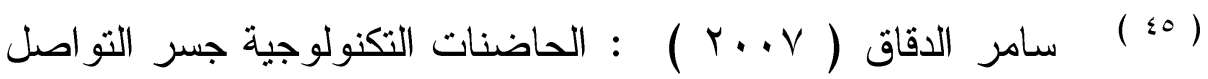

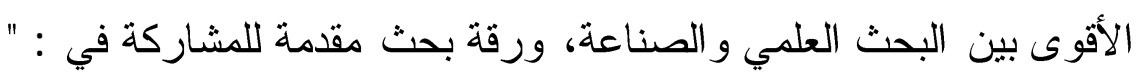

الندوة القومية حول أهمية البحث العلمي والتطوير التكنولوجي في مجال

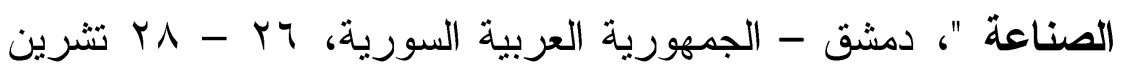

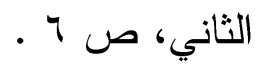

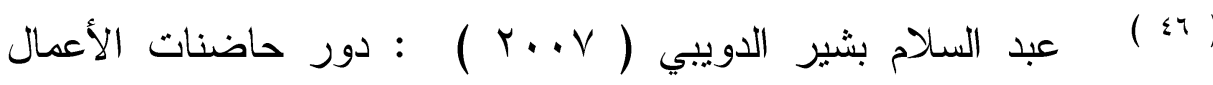

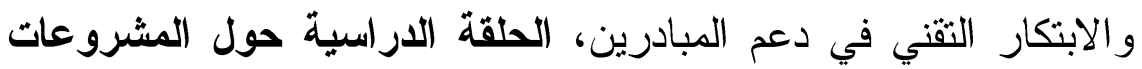

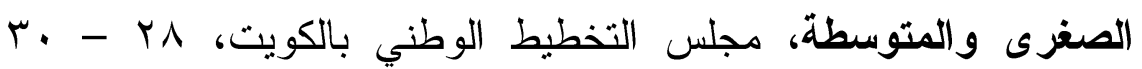

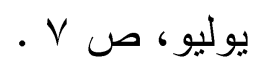

( : ) Aerts, Kris,and Matthyssens, Paul,and Vandenbempt, Koen ( 2007 ): Critical role and screening practices of European business incubators, Elsevier, Technovation No, 27, P 255 , Avaliable at www.sciencedirect.com/

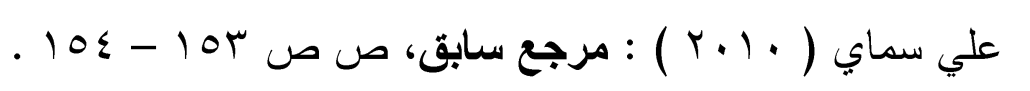

( ( ) Tang, Mingfeng and Others ( 2010 ): “ Technology Business Incubators in China and in India: A comparative analysis ",( Globelics - $8^{\text {th }}$ International Conference Making Innovation Work for Society: Linking, Leveraging and Learning ), University of Malaya, Kuala Lumpur, Malaysia, 1-3 November, PP 3 - 4.

\section{( o. ) Ibid, P 4.}

( o) ) Tang, Mingfeng \& Matt, Mireille ( 2010 ): Management of University Incubators in China and in France: A Comparative Analysis, Chamer de Commerce et d'industrie France en China ( CCIFC ), Beijing, $22^{\text {nd }}$ June, P 3. 


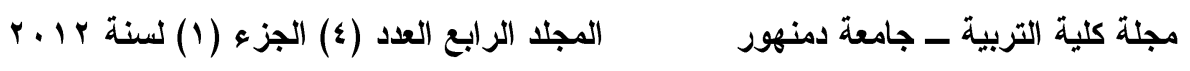

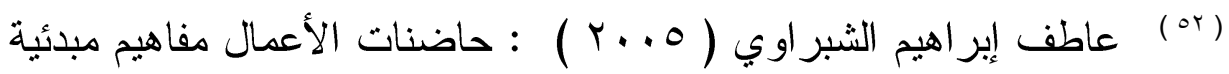
وتجارب عالمية، مرجع سابق.

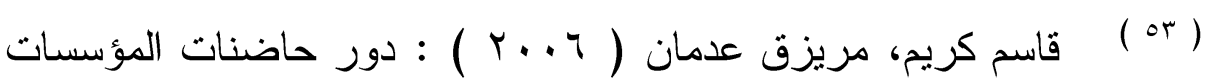
الصغيرة و المتوسطة، الملتقى الدولي: متطلبات تأهيل المؤسسات الصغيرة و المتوسطة في الدول العربية، مخبر العولمة و اقتصاديات شمال

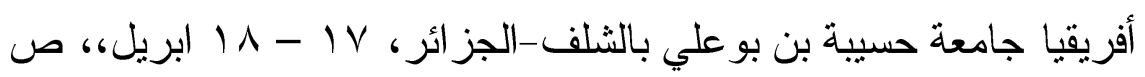

$$
\text { ص ص .001-00 }
$$

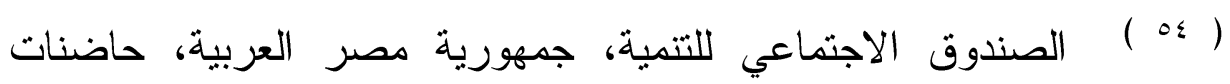
الأعمال التكنولوجية، مرجع سابق.

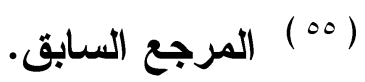

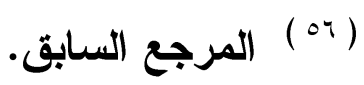

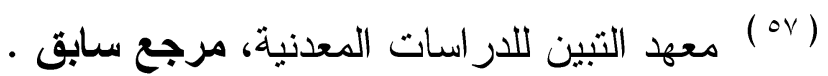

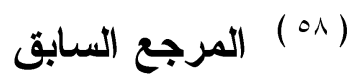

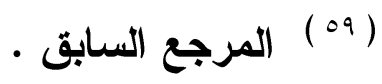

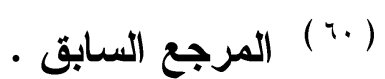

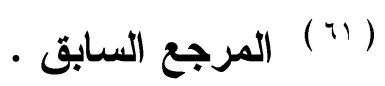

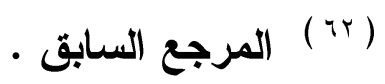

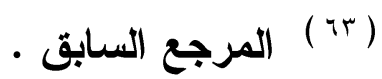

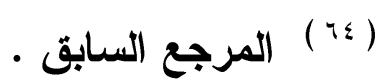

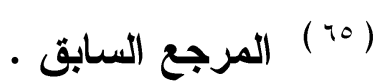

(זr ) المرجع السابق ل

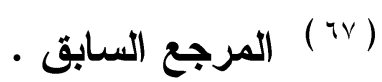




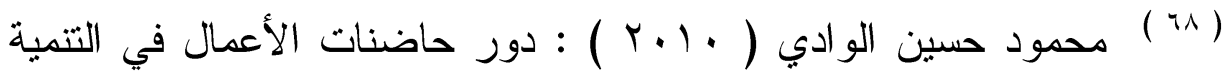

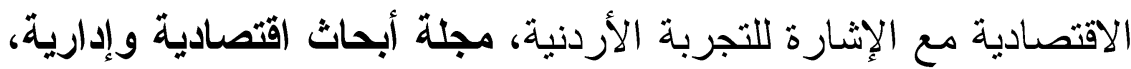

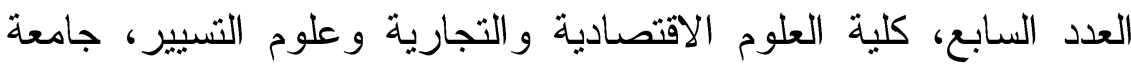

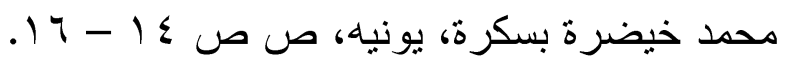




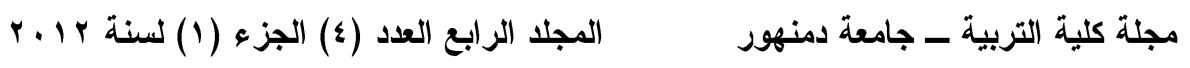

\begin{tabular}{|c|c|c|}
\hline الوظيفة & 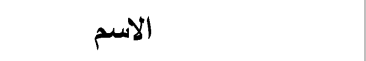 & 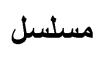 \\
\hline جامعة دمنهور الإدارة التعليمية المتفرغ بكلية التربية & أ ـ د / إسماعيل محمد دياب & .1 \\
\hline - جامعة دمنهور أنفاذ علنف التربوي وعميد كلية التربية & أ ـ ـ د / عادل السعيد البنا &.$r$ \\
\hline أستاذ الإدارة التعليمية ووكيل كلية التربية & أ ـ ـ د / فتحي درويش عشيبة & r \\
\hline أستاذ الإدارة التعليمية ووكيل كلية التربية & أ ـ د / محمد إبراهيم أبو خليل &.$\varepsilon$ \\
\hline - جامعة دمنهور & أ ـ ــ / سامي فتحي عمارة & .0 \\
\hline أستاذ أصول التربية المساعد كلية التربية - & د / وفاء حسن مرسي & .7 \\
\hline مدرس أصول التربية كلية التربية - جامعة & د / فاطمة أبو النور محمد &.$V$ \\
\hline دمنهور أصول التربية كلية التربية - جامعة & د / خميس فهيم عبد الفتاح &.$\wedge$ \\
\hline مدرس أصول التربية كلية التربية - جامعة & لد / محمد عبد الحكيم هلال & .9 \\
\hline
\end{tabular}




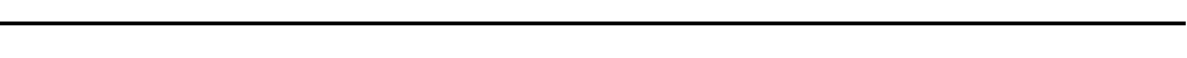

